\title{
DEEP-WATER CANYONS AND SEQUENCE-STRATIGRAPHIC FRAMEWORK OF THE UPPER JURASSIC NAKNEK FORMATION, COOK INLET FOREARC BASIN, SOUTH-CENTRAL ALASKA
}

Trystan M. Herriott, Marwan A. Wartes, and Paul L. Decker

Report of Investigation 2017-4

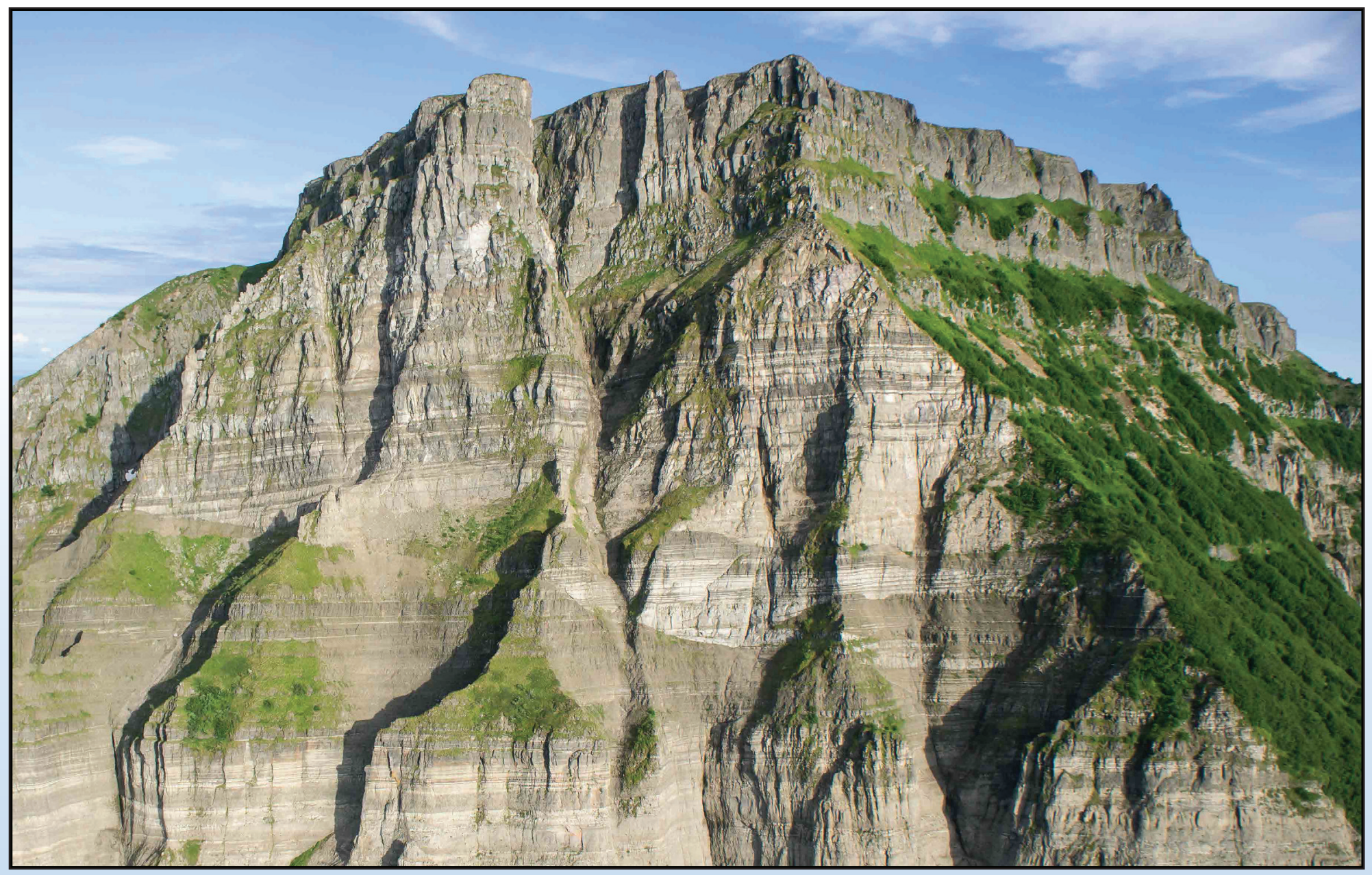

ALASKA DEPARTMENT OF NATURAL RESOURCES DIVISION OF GEOLOGICAL \& GEOPHYSICAL SURVEYS

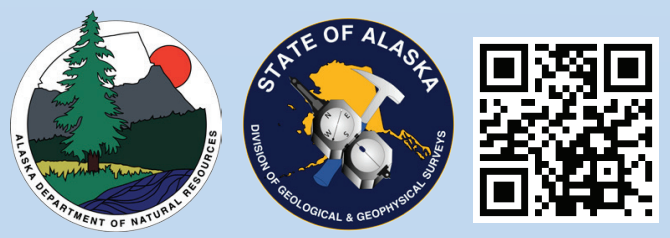


Front cover. Oblique aerial view southeastward of Chisik Island summit area. This mountain-scale exposure of Naknek Formation exhibits evidence of a Late Jurassic deep-water canyon incised into slope strata of Snug Harbor Siltstone Member (gray-brown, wedge-shaped succession at left of exposure) and ultimately backfilled with basin-floor sandstones of the Pomeroy Arkose Member (at and below the summit ridge). Stratigraphic studies of the Naknek Formation along the $\sim 80-k m$-long Iniskin-Tuxedni bays outcrop belt led to the recognition of three deep-water paleocanyons. These discoveries and related work permit the first sequence-stratigraphic interpretation for the Naknek Formation in the hydrocarbon-bearing Cook Inlet forearc basin. See figures 4 and 17A for photogeologic rendition and sequence-stratigraphic interpretation, respectively, of this Chisik Island locality. This part of the exposure is $\sim 275 \mathrm{~m}$ tall, for sense of scale. Photograph by T.M. Herriott. 


\title{
DEEP-WATER CANYONS AND SEQUENCE-STRATIGRAPHIC FRAMEWORK OF THE UPPER JURASSIC NAKNEK FORMATION, COOK INLET FOREARC BASIN, SOUTH-CENTRAL ALASKA
}

Trystan M. Herriott, Marwan A. Wartes, and Paul L. Decker

Report of Investigation 2017-4

\author{
Alaska Department of Natural Resources \\ Division of Geological \& Geophysical Surveys \\ 3354 College Road \\ Fairbanks, Alaska 99709-3707 \\ (907) 451-5010 | dggspubs@alaska.gov \\ website: dggs.alaska.gov
}


STATE OF ALASKA

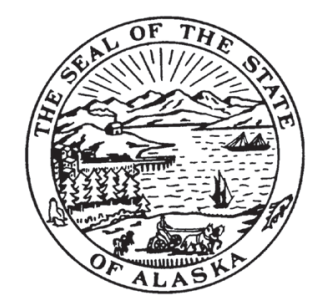

Bill Walker, Governor

DEPARTMENT OF NATURAL RESOURCES

Andrew T. Mack, Commissioner

DIVISION OF GEOLOGICAL \& GEOPHYSICAL SURVEYS

Steve Masterman, State Geologist and Director

Publications produced by the Division of Geological \& Geophysical Surveys (DGGS) are available for free download from the DGGS website (dggs.alaska.gov). Publications on hard-copy or digital media can be examined or purchased in the Fairbanks office:

\section{Alaska Division of Geological \& Geophysical Surveys}

3354 College Rd., Fairbanks, Alaska 99709-3707

Phone: (907) 451-5010 Fax (907) 451-5050

dggspubs@alaska.gov|dggs.alaska.gov

DGGS publications are also available at:

Alaska State Library, Historical

Collections \& Talking Book Center

395 Whittier Street

Juneau, Alaska 99811
Alaska Resource Library and Information Services 3150 C Street, Suite 100 Anchorage, Alaska 99503-3982 


\section{TABLE OF CONTENTS}

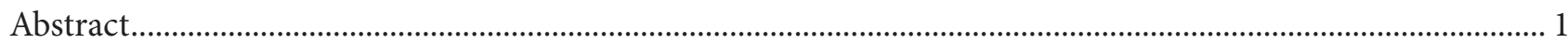

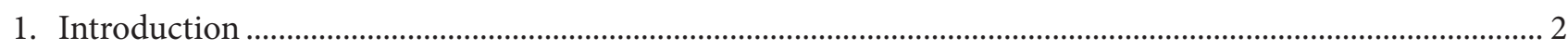

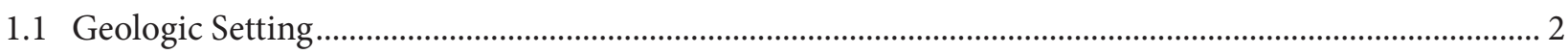

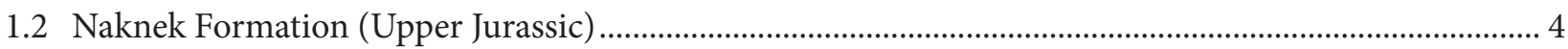

1.2.1 Chisik Conglomerate Member (Lower[?] Oxfordian) ......................................................................... 6

1.2.2 Lower Sandstone Member (Lower to Middle Oxfordian) ...................................................................... 6

1.2.3 Snug Harbor Siltstone Member (Middle to Upper Oxfordian) .......................................................... 6

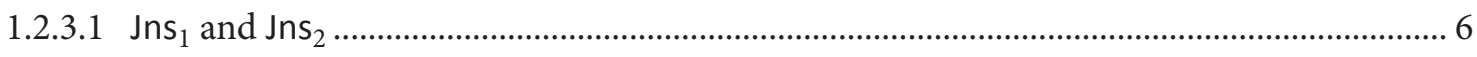

1.2.4 Pomeroy Arkose Member (Lower Kimmeridgian) .......................................................................... 7

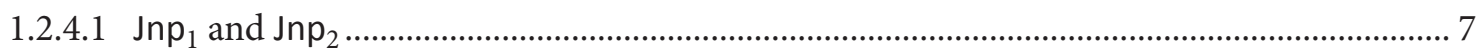

2. Stratigraphic Architecture of the Snug Harbor Siltstone and Pomeroy Arkose Members at Chisik Island, Hickerson Lake, and Mount Pomeroy ........................................................................................... 7

2.1 Methods_Photogeologic Mapping .................................................................................................................

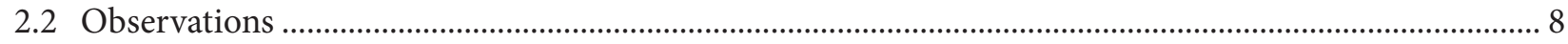

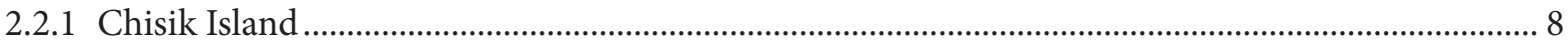

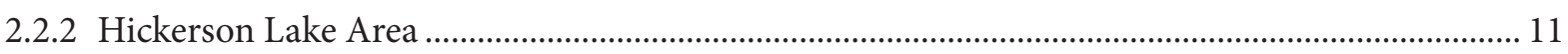

2.2.3 Mount Pomeroy Area ...................................................................................................................... 15

2.3 Interpretations and Discussion-Deep-Water Canyons and Associated Stratigraphic Elements .......... 19

2.3.1 Canyon Establishment and Confinement............................................................................................. 24

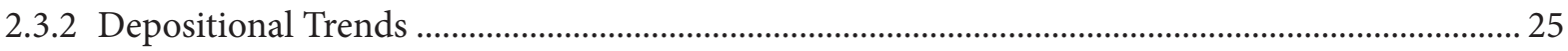

2.3.3 Canyon Orientation, Morphology, and Spacing ............................................................................ 27

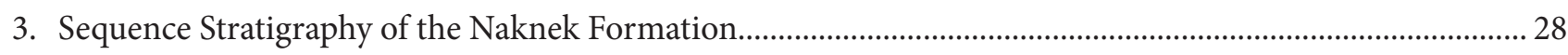

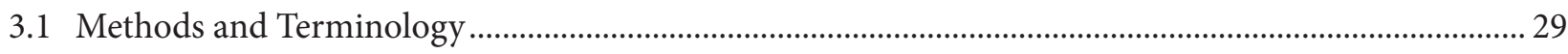

3.2 Naknek Formation Surfaces, Systems Tracts, and Stratigraphic Sequences ...........................................29

3.3 Naknek Formation Base-Level Cycles, Shoreline Trends, and Depositional Systems.............................. 34

3.3.1 Driving Forces of Naknek Formation Sediment Supply and Base-Level Changes ........................ 37

4. Implications for Potential Naknek Formation Reservoirs in the Cook Inlet Subsurface................................. 38

4.1 Distribution of Coarse-Grained Facies in the Lowstand Systems Tracts................................................ 39

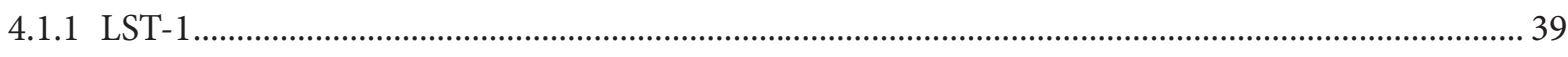

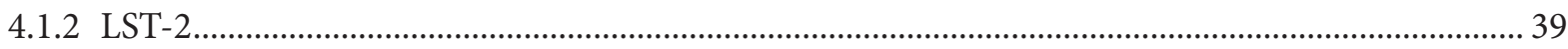

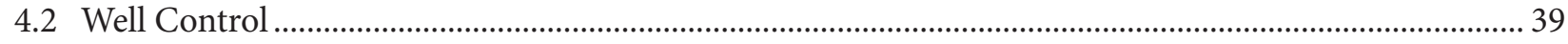

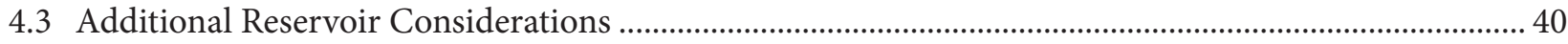

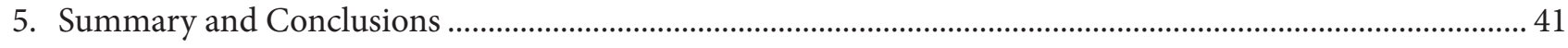

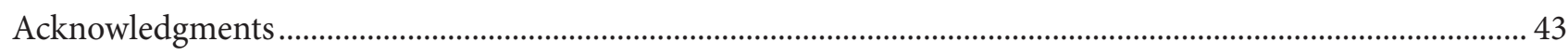

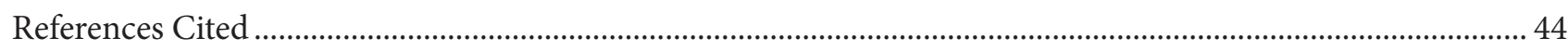




\section{FIGURES}

1. Location map of the Iniskin-Tuxedni bays study area ............................................................................... 3

2. Simplified geologic map of lower Cook Inlet, with study area extending along the outcrop trend

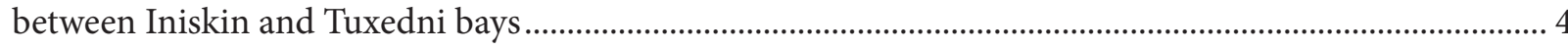

3. Geologic maps of the Hickerson Lake and Mount Pomeroy areas ................................................................... 5

4. Oblique aerial view southeastward of the northern extent of Chisik Island ................................................. 9

5. Photographs of the $>5$-m-thick, boulder-bearing cobble conglomerate in the Snug Harbor Siltstone Member $\left(\mathrm{Jns}_{2}\right)$, southwest shore of Hickerson Lake.

6. Oblique aerial view southwestward of peak 3140 area, with the southwestern shoreline of

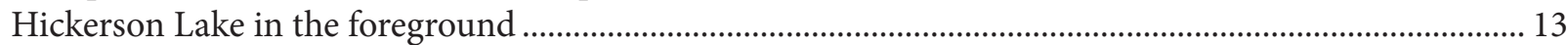

7. Photographs of the area northeast of Hickerson Lake ................................................................................... 14

8. Photographs of two cirque headwalls 3-4 km northeast of Hickerson Lake........................................... 16

9. Photographs of the Mount Pomeroy area ……............................................................................................... 18

10. Oblique aerial photographs depicting stratigraphic relations in the Snug Harbor Siltstone (Jns) and Pomeroy Arkose (Jnp) Members of the Mount Pomeroy area between Iniskin and Oil bays ............ 20

11. Photographs of $\mathrm{Jnp}_{1}$ arkose and conglomerate at Iniskin Bay...................................................................... 22

12. Schematic block diagram of a generalized marine delta-shelf-slope-base-of-slope-basin-floor depositional profile, with a submarine canyon incised into slope strata and bounded by master levees along its lower reaches near the base of the slope

13. Schematic cross sections of confinement mechanisms for deep-water channel systems with two end members

14. Generalized block diagram exhibiting stratigraphic and structural relations of the basin margin associated with the Naknek Formation deep-water canyons ......................................................................... 26

15. Schematic, down-dip view of a generalized Naknek Formation deep-water canyon ................................. 28

16. Schematic framework of sequence-stratigraphic surfaces and systems tracts employed by this study.....29

17. Oblique aerial photographs depicting mountain-scale outcrop expression of sequence-stratigraphic and lithostratigraphic units and surfaces in the Naknek Formation of canyon-associated areas ...... 30

18. Oblique aerial photographs depicting mountain-scale outcrop expression of sequence-stratigraphic and lithostratigraphic units and surfaces in the Naknek Formation of inter-canyon areas ..... 


\title{
DEEP-WATER CANYONS AND SEQUENCE-STRATIGRAPHIC FRAMEWORK OF THE UPPER JURASSIC NAKNEK FORMATION, COOK INLET FOREARC BASIN, SOUTH-CENTRAL ALASKA
}

\author{
Trystan M. Herriott' ${ }^{1}$, Marwan A. Wartes ${ }^{1}$, and Paul L. Decker ${ }^{2}$
}

\begin{abstract}
The Naknek Formation records Late Jurassic forearc basin sedimentation and crops out discontinuously along an approximately 1,000 km trend in southern Alaska. Recent work in the Iniskin-Tuxedni bays area yielded depositional environment interpretations for the lower Oxfordian-lower Kimmeridgian Naknek members of Cook Inlet (in ascending order): Chisik Conglomerate (fan delta), lower sandstone (inner shelf), Snug Harbor Siltstone (outer shelf and slope), and Pomeroy Arkose (base of slope and basin floor). Geologic mapping and stratigraphic reconnaissance also led to the discovery of three seismic-scale, deep-water paleocanyons incised into Snug Harbor slope strata and chiefly filled with channelized Pomeroy sandstone. Following incisional establishment of the canyons, confinement was maintained by erosional and aggradational processes, with indications of the latter in anomalously thick successions of Snug Harbor that crop out immediately adjacent to fill strata and are interpreted as channel-belt-bounding master levees. Fill lithologies and stratigraphic architecture reflect an overall reduction of thalweg gradients following an early episode of canyon evolution marked by incision and sediment bypass. Ultimately, canyon-associated depositional systems trended toward aboveseafloor equilibrium profiles as arkosic sediment debouched onto the basin floor and canyon mouths retreated upslope.

Recognition of the deep-water canyons combined with a synthesis of our depositional systems and stratigraphic architecture studies permit a sequence-stratigraphic analysis of the Naknek Formation. The basal members-Chisik Conglomerate and lower sandstone-overlie the Middle Jurassic Chinitna Formation along a sequence-bounding unconformity (basal surface of forced regression) and form a lowstand systems tract (LST-1). A transgressive surface caps LST-1 at the base of Snug Harbor (outer shelf) and is overlain by a transgressive systems tract (TST). The mid Snug Harbor (slope) exhibits a somewhat thicker-bedded and coarser-grained depositional motif, defining a highstand systems tract (HST) lying above a maximum flooding surface at the top of TST. Inception of the deep-water canyons coincided with termination of HST, forming a basal surface of forced regression that in inter-canyon areas is conformable. The lower Pomeroy and two distinct stratigraphic elements of Snug Harbor constitute base-of-slope and basin-floor components of a lowstand systems tract (LST-2). A complete third order ( $10^{6}$ years duration) stratigraphic sequence comprises LST-1 through HST, with LST-2 occurring in the overlying sequence.

Dominant sediment supply signals are recorded by the coarse, arkosic deposits of forced through normal regressions of LST-1 and LST-2, whereas TST and HST reflect episodes of potentially subtle alternation between accommodation-favored (TST) and sediment-supply-favored (HST) conditions. Establishment of a shelf-slope-basin-floor depositional profile by progradation of clinoforms during HST is inferred, with the incipient canyons cut into this HST slope. Accumulation of slope-bypassed sediment of LST-2 occurred along deep-water reaches of diminishing gradient at and beyond the base of slope, ultimately forming a coarse clastic wedge of coalesced basin-floor fan lobes that backstepped and onlapped the inherited slope profile and probably thinned basinward by downlap beyond the outcrop belt. The deep-water canyons and onlapping fan complex are stratigraphic elements and relations well known from seismic reflection datasets around the world but rarely are documented in outcrop.

The Naknek Formation marked the regional onset of ubiquitous batholithic provenance in the forearc, signaling exhumation of the magmatic arc's roots and suggesting tectonism was a driving force of sediment supply during the Late Jurassic. However, there are indications that changing climate modulated Naknek sedimentation regimes, and ostensible glacioeustatic changes have been reported for Callovian-Oxfordian time that may have critically influenced base-level fall and development of the base-of-Naknek sequence boundary. Nevertheless, convergent margin tectonics likely played the dominant role in driving changes in Naknek sediment supply and accommodation, with climate and eustasy contributing subordinate influences on the resultant stratigraphic architecture.

This stratigraphic analysis relates to petroleum systems of the underexplored Cook Inlet by identifying depositional dip gradient domains in the Naknek Formation, defining reaches through time and space characterized by erosion, bypass, and sediment accumulation in the context of base-level cyclicity and sediment supply. Constraints on sediment routing and timing for export of coarse detritus into marine settings improves predictability of facies distribution in the subsurface. However, Naknek sandstones contain a high proportion of labile grains, typically resulting in diagenetic destruction of porosity and permeability during burial. Nevertheless, exploration models may benefit from integrating the depositional systems work of this study, recognizing that provenance, sediment routing, lithologic parameters, and oil charge timing are keys to determining reservoir quality variability for conventional and unconventional plays.
\end{abstract}

\footnotetext{
${ }^{1}$ Alaska Division of Geological \& Geophysical Surveys, 3354 College Road, Fairbanks, Alaska 99709-3707; trystan.herriott@alaska.gov

${ }^{2}$ Alaska Division of Oil and Gas, 550 West 7th Avenue, Suite 1100, Anchorage, Alaska 99501-3560
} 


\section{INTRODUCTION}

The Alaska Division of Geological \& Geophysical Surveys conducted geologic studies in lower Cook Inlet (fig. 1) as part of a multi-agency collaboration with the Alaska Division of Oil and Gas and the U.S. Geological Survey. Six field campaigns in the Iniskin-Tuxedni bays area since 2009 focused on the Mesozoic stratigraphy and deformational history near the arc-forearc boundary (figs. 1 and 2) (Gillis, 2013, 2014; Wartes, 2015a; Herriott, 2016), aiming to further delineate the petroleum potential of the region and build on the geologic framework established by Detterman and Hartsock (1966). As part of this program, sedimentologic and stratigraphic work on the Upper Jurassic Naknek Formation rendered new understanding of the unit's depositional environments and stratigraphic architecture (Wartes and others, 2011, 2013, 2015; LePain and others, 2013; Herriott and Wartes, 2014; Herriott and others, 2015a, 2015b, 2015c, 2016a). This work is complemented by detailed geologic mapping along the Iniskin-Tuxedni bays outcrop trend, yielding additional insights into the Naknek Formation's lithostratigraphic relations (Herriott and Wartes, 2014; Herriott and others, 2015a). During the course of these investigations we identified three seismic-scale exposures of sand-prone, channelized successions hosted in finer-grained, tabular-bedded strata, with large-scale erosional surfaces separating the two stratigraphic motifs; field relations at these localities were preliminarily described by Herriott and Wartes (2014) and Herriott and others (2015a, 2016a) and interpreted as the stratigraphic record of deep-water canyons and associated processes.

This paper presents a stratigraphic analysis of bed- to map-scale $(1: 63,360)$ observations, indicating establishment and filling of three deep-water canyons (section 2). Recognition of these canyons, consideration of our published and ongoing process-response sedimentologic studies, and examination of member-scale stratigraphic surfaces elucidate sedimentation trends and cycles of the Late Jurassic forearc basin and permit the first sequence-stratigraphic interpretation for the Naknek Formation in Cook Inlet (section 3). The sequencestratigraphic analysis, including a canyon-associated model for sediment dispersal, improves predictability of facies distribution in the basin's subsurface (sections 3 and 4). Additionally, the shallow- to deep-marine depositional settings described in this paper provide constraints for permissible sediment routing pathways that may have influenced sandstone modal compositions in the Naknek Formation (section 4). The findings of this study are relevant to exploration of Cook Inlet's prolific, economically significant yet underexplored petroleum systems (LePain and others, 2013), and channelized, deep-water depositional systems similar to those described here have become increasingly prospective global exploration targets during the past several decades (for example, Posamentier and Kolla, 2003; Mayall and others, 2006; Hubbard and others, 2014).

\subsection{Geologic Setting}

Cook Inlet, in south-central Alaska, is a long-lived forearc basin (Dickinson, 1995) with a Jurassic through Cenozoic stratigraphic record approximately $20 \mathrm{~km}$ thick (Fisher and Magoon, 1978; LePain and others, 2013). Middle (Tuxedni Group and Chinitna Formation) and Upper (Naknek Formation) Jurassic forearc basin strata crop out southeast of the northwest-dipping Bruin Bay fault system near the arc-forearc margin of lower Cook Inlet (fig. 2). Talkeetna arc rocks-remnants of which constitute part of the Alaska-Aleutian Range batholith and the Lower Jurassic volcanogenic Talkeetna Formation (figs. 1 and 2) - dominantly lie northwest of the Bruin Bay fault system; the intraoceanic Talkeetna arc (Clift and others, 2005; Rioux and others, 2010) likely was active during Tuxedni-Naknek sedimentation (Detterman and Hartsock, 1966; Detterman and Reed, 1980; Wartes and others, 2011, 2013; LePain and others, 2013). Regionally, the Border Ranges fault system defines the Cook Inlet forearc basin's southeastern, trenchward margin, where an emergent, Mesozoic and younger accretionary prism is present (fig. 1) (Pavlis and Roeske, 2007).

The Middle and Upper Jurassic forearc basin stratigraphy is chiefly marine in outcrops of the Iniskin-Tuxedni bays area and records unroofing of the Talkeetna arc's volcanic carapace (Lower Jurassic Talkeetna Formation) and its Jurassic-age plutonic roots, with basin fill trending from volcanic rock fragment-rich (Tuxedni Group and Chinitna Formation) toward arkosic (Naknek Formation) (Detterman and Hartsock, 1966; Kirschner and Lyon, 1973; Fisher and Magoon, 1978; Detterman and Reed, 1980; Trop and others, 2005; Trop and Ridgway, 2007; Helmold and others, 2013; LePain and others, 2013). The Talkeetna arc batholith in lower Cook Inlet exhibits intermediate to felsic compositions (Reed and Lanphere, 1973; Reed and others, 1983; Rioux and 


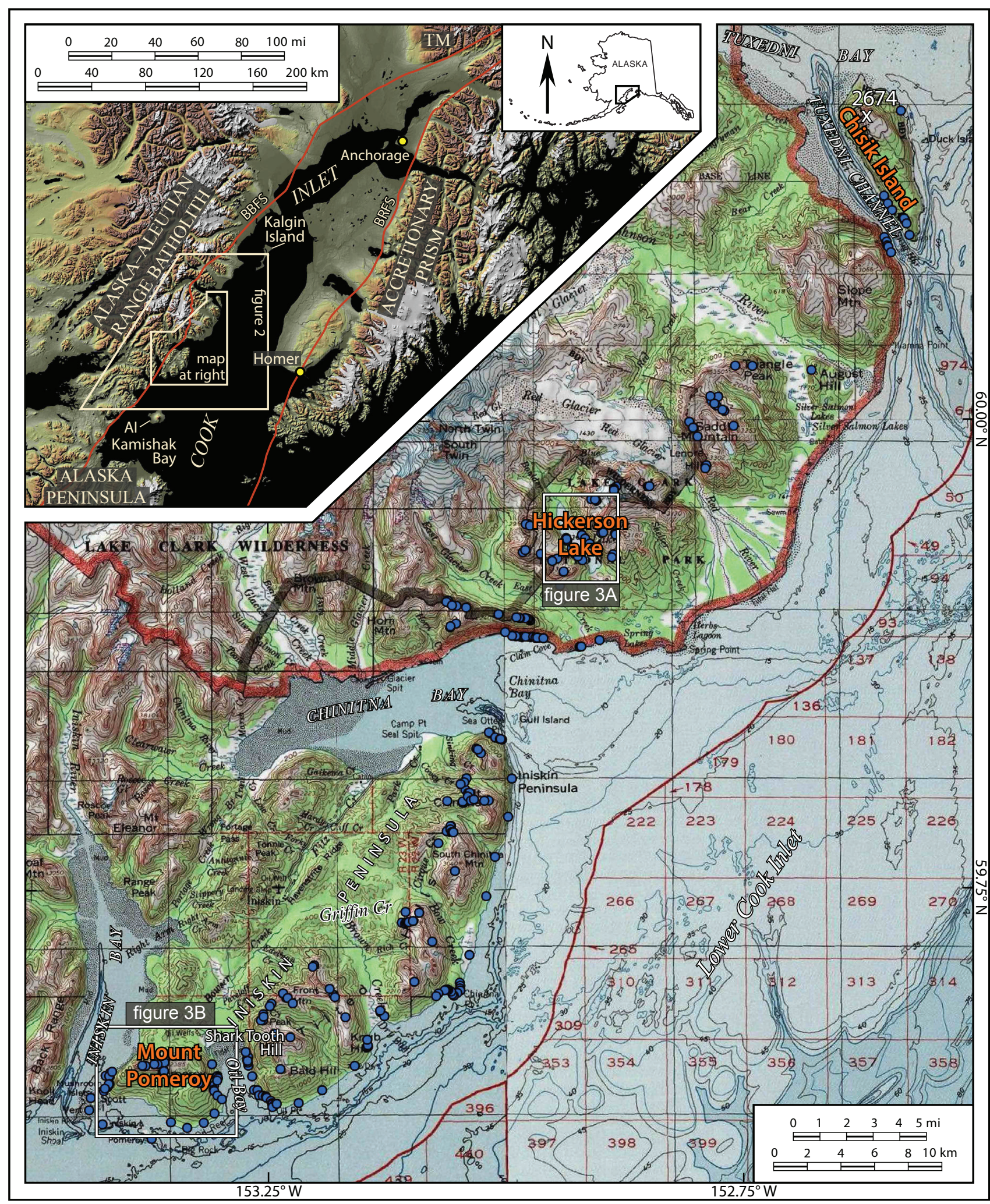

Figure 1. Location map of the Iniskin-Tuxedni bays study area. The authors made detailed observations of the Naknek Formation at more than 325 localities (blue dots) during six field seasons. Note Chisik Island and the Hickerson Lake and Mount Pomeroy areas (orange labels), which are discussed in detail in this report. Lower Cook Inlet is typically regarded as the part of the basin that lies between Kalgin Island and Kamishak Bay (Fisher and Magoon, 1978; LePain and others, 2013). Bruin Bay (BBFS) and Border Ranges (BRFS) fault systems are modified from LePain and others (2013). Topographic base map from portions of U.S. Geological Survey Iliamna, Seldovia, Lake Clark, and Kenai 1:250,000-scale quadrangles; shaded-relief image modified from U.S. Geological Survey Elevation Data Set Shaded Relief of Alaska poster. Additional abbreviations: Al = Augustine Island; TM = Talkeetna Mountains. 
others, 2010), consistent with the framework composition of Naknek Formation sandstones (for example, Helmold and others, 2013).

\subsection{Naknek Formation (Upper Jurassic)}

The Upper Jurassic Naknek Formation (Spurr, 1900; Martin, 1905; Martin and Katz, 1912) is recognized along a discontinuous outcrop belt in southern Alaska that extends for more than $1,000 \mathrm{~km}$ from the Alaska Peninsula northeastward through Cook Inlet and into the Talkeetna Mountains (fig. 1) (Wilson and others, 1998, 2012; LePain and others, 2013). In the Iniskin-Tuxedni bays study area, the Naknek Formation comprises marine strata that have been variously divided into lithostratigraphically defined members (Moffit, 1927; Kirschner and Minard, 1949; Hartsock, 1954; Detterman and Hartsock, 1966; also Detterman and others, 1996; Wilson and others, 2012). Recent geologic mapping on the Iniskin Peninsula (Herriott and Wartes, 2014; also Gillis and others, 2014) and north of Chinitna Bay followed the four-member division of Detterman and Hartsock (1966) (in ascending order): Chisik Conglomerate, lower sandstone (informal), Snug Harbor Siltstone, and Pomeroy Arkose (fig. 3). Marine faunal assemblages indicate these members range from lower Oxfordian through lower Kimmeridgian (Imlay, 1981), an interval spanning approximately 9 million years (Ogg and Hinnov, 2012). Member ages reported below are after Imlay (1981), although the Chisik is non-fossiliferous and its age is inferred. On the Iniskin Peninsula (fig. 1), the Naknek Formation is typically greater than 1,300 $\mathrm{m}$ thick (Herriott and Wartes, 2014). A partly comparable stacking of Naknek members or probable equivalents is reported on the Alaska Peninsula (Detterman and others, 1996), but the Pomeroy Arkose Member is limited to the Iniskin-Tuxedni bays area and an isolated locality on Augustine Island (fig. 1) (Wilson and others, 2012).

Naknek Formation strata in the study area are well exposed within an approximately $80-\mathrm{km}$-long outcrop

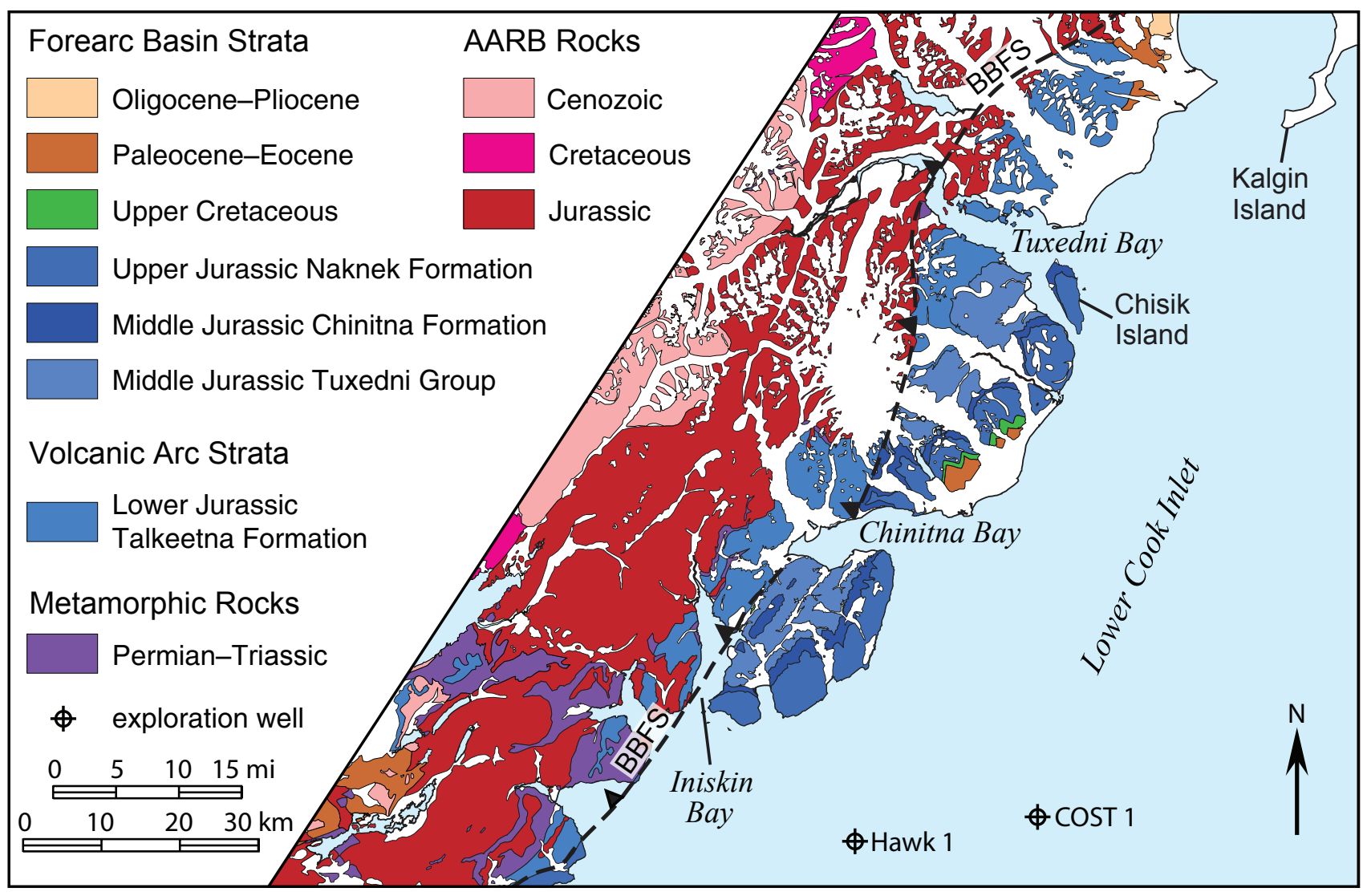

Figure 2. Simplified geologic map of lower Cook Inlet, with the study area extending along the outcrop trend between Iniskin and Tuxedni bays. Middle Jurassic and younger forearc basin strata, including the Naknek Formation, lie southeast of the Bruin Bay fault system (BBFS), which is generally regarded as the forearc basin margin (LePain and others, 2013); Lower Jurassic volcanic strata and Jurassic plutonic rocks of the Talkeetna arc (see Alaska-Aleutian Range batholith [AARB]) dominantly crop out northwest of the BBFS. Figure modified from Betka and Gillis (2015) and Wartes (2015b); geologic map modified from regional compilation by Wilson and others (2009, 2012). 
trend that mainly parallels structural strike and the basin-margin-defining elements of the Bruin Bay fault system and the Alaska-Aleutian Range batholith (fig. 2). Deviations from this regional pattern occur locally; for example, the Naknek stratigraphy strikes east near Iniskin Bay (fig. 3B), reflecting a structural trend in the southwest-plunging nose of the Fitz Creek anticline (Detterman and Hartsock, 1966). Chiefly consistent within-member facies associations for each
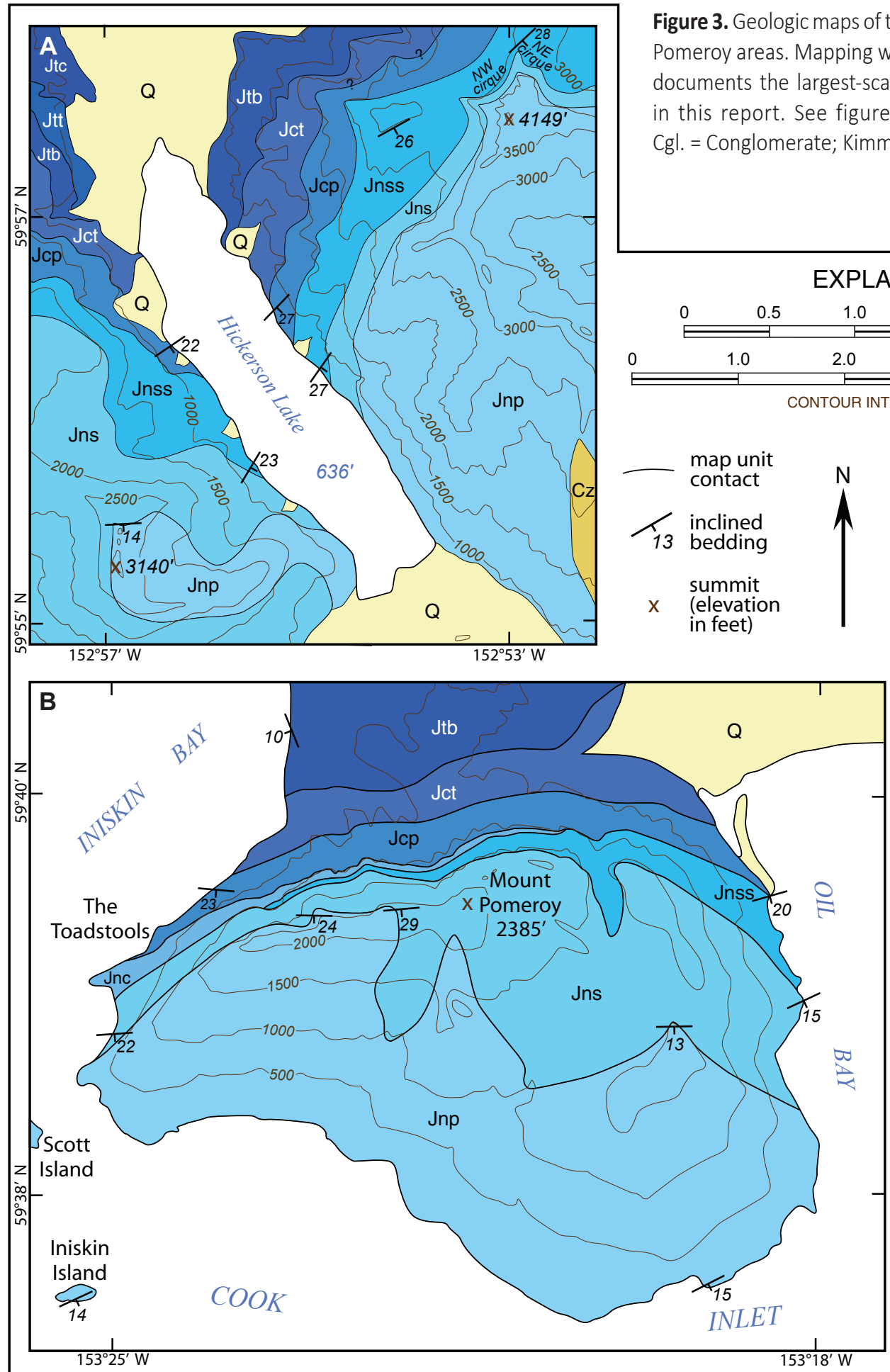

of the Naknek members are observed throughout the study area, supporting an inference that structural strike is generally parallel to depositional strike of the Late Jurassic depositional systems. Exceptions to the along-strike facies uniformity occur in the Naknek, and are discussed in this paper, yet remain compatible with the structural strike as approximate depositional strike equivalency. Marked lithologic variability in each Naknek member is likely in the inferred southeastward

Figure 3. Geologic maps of the (A) Hickerson Lake and (B) Mount Pomeroy areas. Mapping was conducted at 1:63,360 scale and documents the largest-scale stratigraphic relations described in this report. See figure 1 for index map. Abbreviations: $\mathrm{Cgl}$. = Conglomerate; Kimm. $=$ Kimmeridgian; $\mathrm{mbr}$. = member.

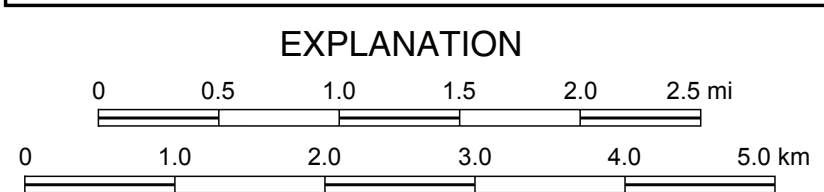

CONTOUR INTERVAL 500 FEET

\begin{tabular}{|c|c|c|c|}
\hline & $\begin{array}{l}\text { map unit } \\
\text { contact }\end{array}$ & \multicolumn{2}{|r|}{$\begin{array}{l}\text { QUATERNARY } \\
\text { SEDIMENTS }\end{array}$} \\
\hline & inclined & $Q$ & $\begin{array}{l}\text { Quaternary deposit } \\
\text { undifferentiated }\end{array}$ \\
\hline & summit & \multicolumn{2}{|c|}{ CENOZOIC STRATA } \\
\hline$X$ & $\begin{array}{l}\text { (elevation } \\
\text { in feet) }\end{array}$ & $\mathrm{Cz}$ & $\begin{array}{l}\text { West Foreland } \\
\text { Formation }\end{array}$ \\
\hline
\end{tabular}


depositional dip direction but only limited proximaldistal intra-member stratigraphic relations are revealed by the modern outcrop belt.

\subsubsection{CHISIK CONGLOMERATE MEMBER (LOWER[?] OXFORDIAN)}

The Chisik Conglomerate Member is a gray-weathering, poorly organized, very-thick-bedded conglomerate unit with subordinate sandstone (Detterman and Hartsock, 1966; Wartes and others, 2013; Herriott and Wartes, 2014). The Chisik unconformably overlies Middle Jurassic (Callovian) strata of the Chinitna Formation at Iniskin Bay (fig. 1), where it is in turn abruptly overlain by the Snug Harbor Siltstone Member (Detterman and Hartsock, 1966; Herriott and Wartes, 2014). The distribution of Chisik in the study area is limited to the Iniskin Bay-Mount Pomeroy trend (Herriott and Wartes, 2014) and the vicinity of Chisik Island. The member is $131 \mathrm{~m}$ thick along the east shore of Iniskin Bay (this study) and depositionally thins to zero approximately $5 \mathrm{~km}$ to the east (fig. 3B). Detterman and Hartsock (1966) regarded the Chisik as a lateral equivalent to the lower sandstone member, although the Chisik is everywhere overlain by the lower sandstone where both members crop out near Mount Pomeroy and at Chisik Island (Herriott and Wartes, 2014; this study). Wartes and others (2011, 2013) interpreted the Chisik Conglomerate Member as recording fan-delta sedimentation.

\subsubsection{LOWER SANDSTONE MEMBER (LOWER TO MIDDLE OXFORDIAN)}

The lower sandstone member is a dominantly tanweathering, thick-bedded, very-fine- to fine-grained sandstone unit (Detterman and Hartsock, 1966; Wartes and others, 2013, 2015; Herriott and Wartes, 2014). Where the Chisik is absent, this informal member unconformably overlies the Chinitna Formation and is sharply and conformably overlain by the Snug Harbor Siltstone Member (Detterman and Hartsock, 1966; Herriott and Wartes, 2014). The lower sandstone is about $240 \mathrm{~m}$ thick on the Iniskin Peninsula (Herriott and Wartes, 2014), but appears to be locally thicker north of Chinitna Bay ( 317 m; Wartes and others, 2015) and is absent at Iniskin Bay (fig. 3B). Wartes and others (2011, 2013) interpreted a storm-influenced shelfal environment for deposition of the lower sandstone member, with examination of additional exposures yielding evidence of lower shoreface processes and a possible deltaic signature (Wartes and others, 2015). We regard the lower sandstone as primarily recording deposition in an inner shelf setting with shoreface and probable deltaic stratigraphic elements and/or influences.

\subsubsection{SNUG HARBOR SILTSTONE MEMBER (MIDDLE TO UPPER OXFORDIAN)}

The Snug Harbor Siltstone Member is a chiefly darkgray-weathering, thin- to thick-bedded siltstone and very-fine-grained sandstone unit that is overlain conformably and unconformably by the Pomeroy Arkose Member (Detterman and Hartsock, 1966; Wartes and others, 2013; Herriott and Wartes, 2014). Detterman and Hartsock (1966) reported the local presence of pebbles in minor sandstone beds, but recent work documented conglomeratic sandstone and pebble to boulder conglomerate as subordinate but notable constituents of the Snug Harbor (Herriott and Wartes, 2014; this study). The member is about $260 \mathrm{~m}$ thick in most exposures on the Iniskin Peninsula (Herriott and Wartes, 2014), but this typical stratigraphic thickness varies significantly in the vicinities of Chisik Island, Hickerson Lake, and Mount Pomeroy (fig. 1; see below). The Snug Harbor Siltstone Member is interpreted to record outer shelf to slope sedimentation (LePain and others, 2013; Wartes and others, 2013); we generally refer to Snug Harbor as a slope unit, but the lower part of the member was likely deposited on an outer shelf (this study). Farther to the southwest on the Alaska Peninsula, Detterman and others (1996) reported that the Snug Harbor was deposited in "moderately deep water" below wave base and above the carbonate compensation depth.

\subsubsection{1 $\mathrm{Jns}_{1}$ and $\mathrm{Jns}_{2}$}

In the Chisik Island and Hickerson Lake areas two divisions of the Snug Harbor Siltstone Member are recognized and denoted with subscripts in this paper $\left(\mathrm{Jns}_{1}\right.$ and $\mathrm{Jns}_{2}$ ). Jns $\mathrm{Jn}_{1}$ represents the typical lithostratigraphic expression of Snug Harbor and is only mapped where a distinction from $\mathrm{Jns}_{2}$ is possible. Jns $\mathrm{J}_{2}$ comprises thick, channelized successions of chiefly brown- and gray-weathering arkose, siltstone, and subordinate conglomerate; channel-form sediment bodies of $\mathrm{Jns}_{2}$ onlap $\mathrm{Jns}_{1}$ along sharp, erosional surfaces that cut across tens to hundreds of meters of stratigraphy. 


\subsubsection{POMEROY ARKOSE MEMBER (LOWER KIMMERIDGIAN)}

The Pomeroy Arkose Member is a typically light-grayweathering, commonly amalgamated, very-thickbedded, arkosic sandstone unit with subordinate, locally well-developed, thin-bedded siltstone and sandstone intercalations; thick packages of siltstone as well as conglomerate are also observed, although arkose and arkosic conglomerate everywhere define the base of the member (Detterman and Hartsock, 1966; Wartes and others, 2013; LePain and others, 2013; Herriott and Wartes, 2014). A minimum thickness for the Pomeroy is $899 \mathrm{~m}$, with the member's top not occurring on the Iniskin Peninsula (Herriott and Wartes, 2014); however, Upper Cretaceous and Cenozoic strata unconformably overlie the Pomeroy in exposures north of Chinitna Bay (Detterman and Hartsock, 1966; Magoon and others, 1980; Bradley and others, 1999; LePain and others, 2012; Wilson and others, 2012; Gillis, 2016). Wartes and others (2013) interpreted the lower Pomeroy Arkose Member to dominantly record deposition from sediment gravity flows and proposed a base-of-slope to basin-floor environment, which is consistent with work by LePain and others (2013). This paper addresses the lower several hundred meters of the Pomeroy.

\subsubsection{1 $\mathrm{Jnp}_{1}$ and $\mathrm{Jnp}_{2}$}

Two divisions in the lower part of the Pomeroy Arkose Member $\left(\mathrm{Jnp}_{1}\right.$ and $\left.\mathrm{Jnp}_{2}\right)$ are recognized by this study and mapped where possible in the Chisik Island, Hickerson Lake, and Mount Pomeroy areas. Distinction between $J n p_{1}$ and $J n p_{2}$ is based on differences in stratal body geometries: $\mathrm{Jnp}_{1}$ hosts conspicuous, large-scale channel forms and $\mathrm{Jnp}_{2}$ is chiefly tabular bodied at the scales of exposure. Analogous to $\mathrm{Jns}_{1}$, $\mathrm{Jnp}_{2}$ represents the typical lithostratigraphic expression of the lower several hundred meters of Pomeroy observed throughout most exposures in the study area and is only distinguished where an underlying Jnp $\mathrm{J}_{1}$ occurs. Channel-form sediment bodies of $\mathrm{Jnp}_{1}$ onlap sharp, erosional surfaces that cut across tens to hundreds of meters of stratigraphy, including $\mathrm{Jns}_{1}$ and $\mathrm{Jns}_{2}$ as well as undifferentiated Snug Harbor (Jns).

\section{STRATIGRAPHIC ARCHITECTURE OF THE SNUG HARBOR SILTSTONE AND POMEROY ARKOSE MEMBERS AT CHISIK ISLAND, HICKERSON LAKE, AND MOUNT POMEROY}

The contact between the Snug Harbor Siltstone and Pomeroy Arkose Members is generally conspicuous, juxtaposing dark-gray-weathering, relatively thinbedded, and fine-grained strata (Snug Harbor) with overlying lighter-gray-weathering, thicker-bedded, and coarser-grained strata (Pomeroy) (Herriott and Wartes, 2014). Detterman and Hartsock (1966) emphasized that the contact is everywhere sharp and conformable except at the southwestern end of Chisik Island, where a minor erosional relation was observed. Detterman and Hartsock (1966) also reported that among the Naknek Formation members the Snug Harbor is distinguished by its remarkable consistency of thickness and lithologic character, indicating a uniform stratigraphy with limited along-strike lithologic variability. Recent work highlighted a transitional facies that is common in the uppermost Snug Harbor, where Pomeroy-like, thick arkose beds occur (Herriott and Wartes, 2014). Additionally, we map thick channelized successions hosted by seismic-scale erosion surfaces associated with the Snug Harbor Siltstone and Pomeroy Arkose in the Chisik Island, Hickerson Lake, and Mount Pomeroy areas (fig. 1, orange labels); these stratigraphic features clearly deviate from the typically conformable, layercake-like stacking of these members. Despite these local stratigraphic complexities in the Snug Harbor to Pomeroy transition, we always map this lithologically defined contact at the base of a thick succession (typically greater than $100 \mathrm{~m}$ ) of amalgamated arkose beds that are locally conglomeratic (see also Herriott and Wartes, 2014).

\subsection{Methods-Photogeologic Mapping}

Photogeologic mapping on oblique-view digital photographs is integral to this study. The photographed localities include kilometer-scale mountainsides and cliff faces where the Naknek Formation crops out. These areas are generally impractical and/or hazardous to access for hands-on examination but permit extraordinary opportunities to document member-scale and smaller stratigraphic architecture. Mountain-scale photographs included here were typically made during helicopter- 
based aerial reconnaissance, although ground-based photographs are employed where applicable. In photographing the exposures, we prioritized alignment of the interchangeable-lens-camera's digital sensor to the approximate plane of the mountainside or cliff face to reduce scale variation in the frame, although this was not always accomplished or practical. Azimuths of viewing directions range from strike- to dip-parallel, with these two end members serving as preferences; viewing directions are noted in photogeologic figure captions and the approximate strike and dip of beds are reported in the figures and text. Photogeologic mapping of lithostratigraphic units and stratal geometries are presented in the observations section below, although we recognize the complexity of making purely objective geologic observations in this context (compare with discussion by Miall and Miall, 2001). Sequence-stratigraphic interpretations for some of the photogeologic figures of this study and from Herriott and Wartes (2014) are included in section 3 of this paper.

Photogeologic mapping was conducted in coordination with 1:63,360-scale geologic mapping of the Naknek Formation between Iniskin Bay and Johnson River (DGGS, unpublished data) and additional stratigraphic reconnaissance between Johnson River and Tuxedni Bay, including Chisik Island (fig. 1). Outcrop and subcrop character of the Naknek Formation varies as a function of grain size as well as bed thickness and geometry; weathering color of strata-reflecting sediment composition, cementation, and grain size-and distinctive weathering profiles also were employed in distinguishing among the Naknek members. Naknek Formation mapping criteria of the current study are described above and by Herriott and Wartes (2014; see also Detterman and Hartsock, 1966). Additional photographs and observations made from multiple perspectives and viewing distances augmented the photogeologic mapping, which was completed digitally using Adobe Illustrator ${ }^{\circledR}$ software. We mapped informal, subscripted divisions of the Snug Harbor Siltstone and Pomeroy Arkose Members where lithologic observations permitted these distinctions (see sections 1.2.3.1 and 1.2.4.1). Channel-form sediment body geometries were mapped where observed and other bedding geometries are noted in the figures and text.

Stratigraphic thicknesses labeled on the photogeologic figures and reported in the text were determined by a method similar to the tape-compass-clinometer technique of Compton (1985) but here are based on topographic-map-determined distances between unit contacts rather than tape measure. Where thicknesses are reported as approximate, the geometric calculations relied on contacts that are inaccessible but readily mapped from a distance. Where thicknesses are reported to the nearest meter, the geometric calculations relied on contacts that were visited by the authors, who collected precise latitude and longitude coordinates with handheld Global Positioning System (GPS) receivers. We compared both variants of our employed method to several Naknek member thicknesses determined by Jacob staff (Wartes and others, 2015; DGGS, unpublished data) and reported by Detterman and Hartsock (1966); these comparisons generally yielded results within 10 percent of the aforementioned sources.

\subsection{Observations}

\subsubsection{CHISIK ISLAND}

Chisik Island lies in Tuxedni Bay at the northeastern end of the study area, and hosts Cook Inlet's northernmost exposures of the Naknek Formation (Wilson and others, 2012). All four members of the Naknek crop out in a steep and largely inaccessible mountainside north of peak 2674 (fig. 1), with strata dipping gently $\left(\sim 15^{\circ}\right)$ to the southeast. The stratigraphic architecture at this locality was preliminarily outlined by Herriott and others (2016a).

Aerial stratigraphic reconnaissance and photogeologic mapping of the Naknek members, sub-member-scale lithostratigraphic units, and channel-form sediment bodies at the Chisik Island locality delineate prominent concave-up erosional surfaces in the upper Snug Harbor through lower Pomeroy (fig. 4, Jns 2 and $\mathrm{Jnp}_{1}$ ).

Figure 4 (opposite page). Oblique aerial view southeastward of the northern extent of Chisik Island. Key stratigraphic relations in the Snug Harbor Siltstone (Jns) and Pomeroy Arkose (Jnp) Members (and subscripted divisions) are discussed in the text. (A) Oblique aerial photograph. (B) Photogeologic rendition. (C) Line-drawing rendition. View toward center of photograph is nearly dip-direction parallel, with beds dipping $\sim 15^{\circ}$ southeastward (into and toward left of photograph). Approximately $400 \mathrm{~m}$ of topographic relief lie between peak 2674 and the base-of-cliff exposures of Chisik Conglomerate Member (Jnc), for sense of scale; the exposure is 900 m wide at brush line near the Naknek-Chinitna Formations contact. A-C are modified from Herriott and others (2016a). 

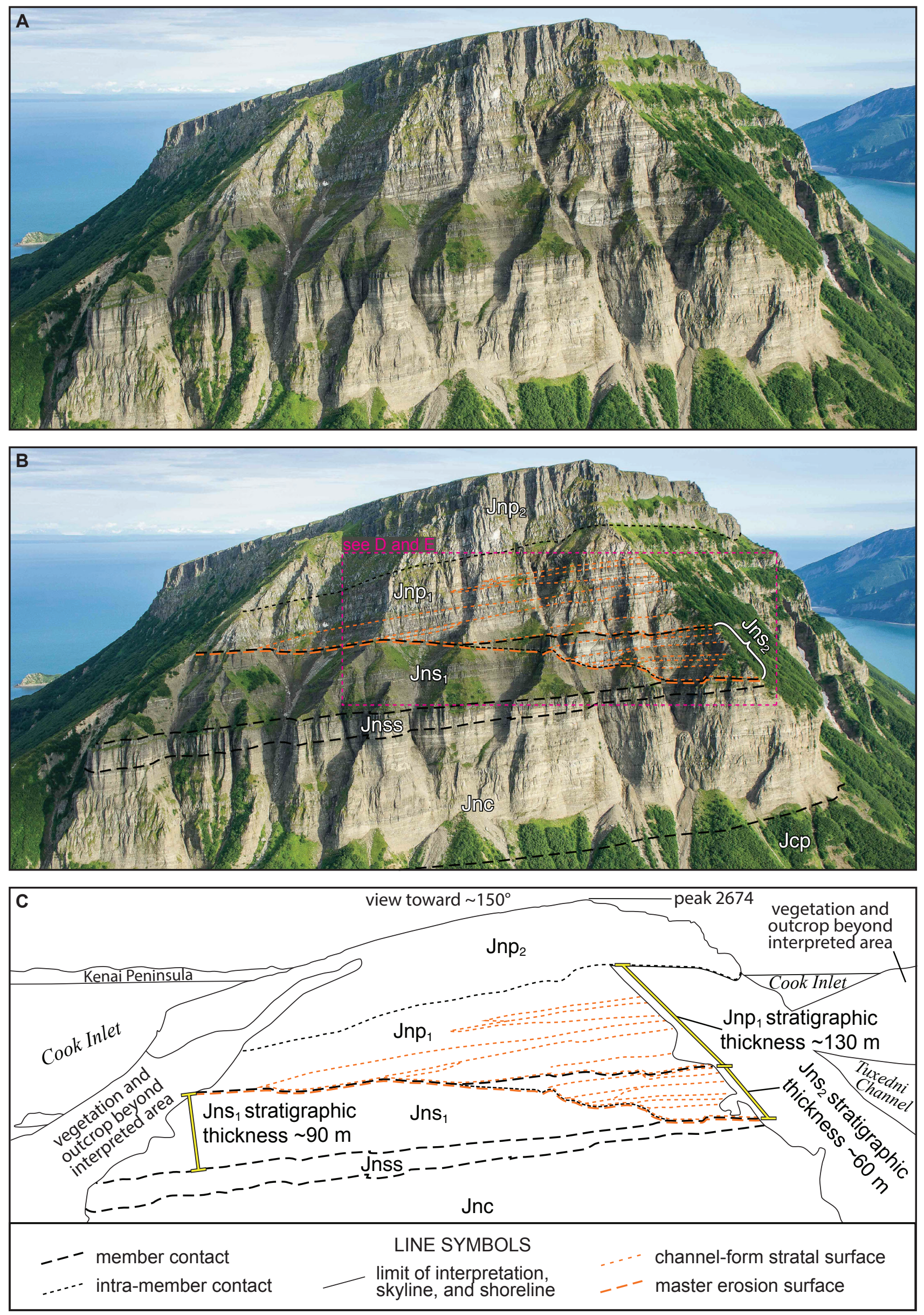

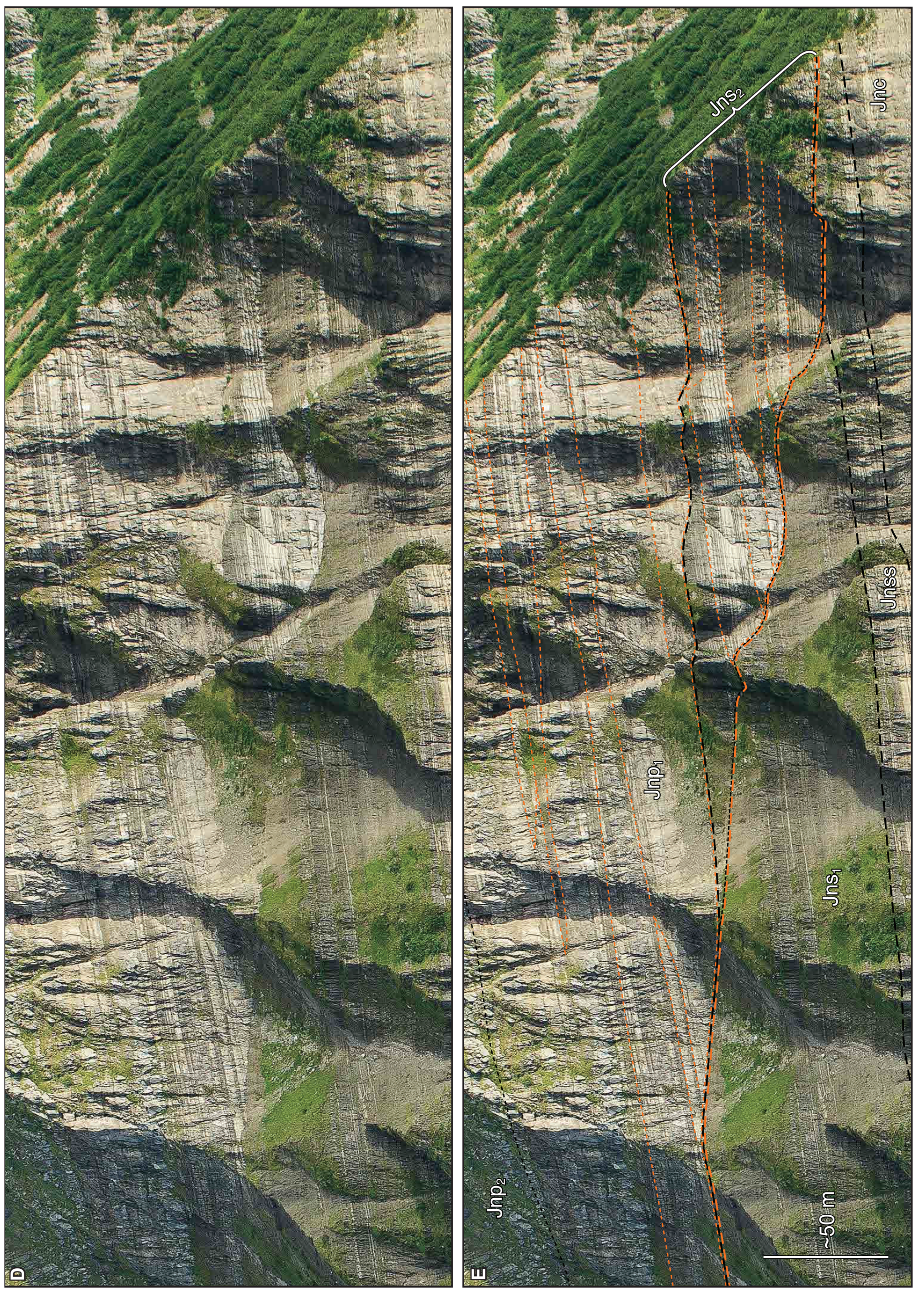

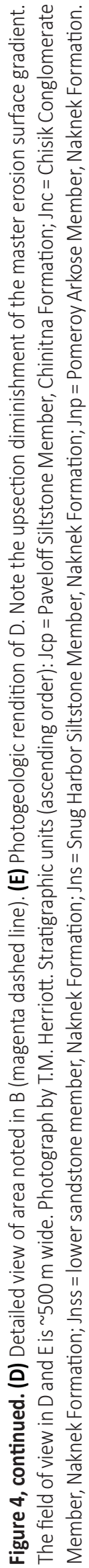


This channelized succession lies above the exposure's highest rank (in the sense of Catuneanu and others, 2009), seismic-scale erosional surface (fig. 4, master erosion surface [orange long-dashed line]), which cuts down through more than approximately $90 \mathrm{~m}$ of stratigraphy and preserves an underlying, apparently northeastward-thickening wedge of dark-gray-weathering, tabular-bedded siltstone and subordinate sandstone of typical Snug Harbor facies $\left(\mathrm{Jns}_{1}\right)$. This high-relief erosional surface separates lithologically and architecturally distinct Jns ${ }_{1}$ and $J n s_{2}$ in the central-right area of figure 4 and juxtaposes the lower sandstone member with $\mathrm{Jns}_{2}$ to the southwest, where $\mathrm{Jns}_{1}$ is entirely truncated (see farthest right of fig. $4 \mathrm{E}$ ). $\mathrm{Jns}_{2}$ is up to approximately 60 $\mathrm{m}$ thick and distinguished from $\mathrm{Jns}_{1}$ in that it crops out above the master erosion surface and hosts channelform sediment bodies as well as abundant, thick arkose beds. Channel-fill packages in $\mathrm{Jns}_{2}$ range from grayweathering, thickly bedded, amalgamated arkoses to thinner-bedded successions of intercalated arkose and brown-weathering siltstone (fig. $4 \mathrm{D}$ and E).

We map the Snug Harbor-Pomeroy contact at the base of the very thick (tens of meters) accumulations of channelized, amalgamated arkoses $\left(\mathrm{Jnp}_{1}\right)$ that overlie $\mathrm{Jns}_{1}$ and $\mathrm{Jns}_{2}$. Jnp $\mathrm{Ji}_{1}$ is up to approximately $130 \mathrm{~m}$ thick and silty strata are only a minor constituent (see dark-weathering $\mathrm{Jnp}_{1}$ beds in fig. 4). Channel-fills of $\mathrm{Jns}_{2}-\mathrm{Jnp_{1 }}$ exhibit an upsection trend of diminishing channel margin gradients (in approximately crosssectional views). This trend at least in part corresponds to the geometry of the master erosion surface, which has a lower margin gradient in its upper part. Many of the mapped channel bodies in $\mathrm{Jns}_{2}$ and $\mathrm{Jnp}_{1}$ directly onlap and merge with the master erosion surface, demonstrating the composited nature of this surface (fig. 4D and E). The Naknek is capped near peak 2674 by a Pomeroy interval mapped as Jnp ${ }_{2}$, which contains thicker amalgamated arkosic packages than are observed in $\mathrm{Jnp}_{1}$, is dominantly tabular-bodied at the scale of exposure, and lacks silty interbeds (that is to say, is consistent with the typical lithostratigraphic expression of lower Pomeroy Arkose Member).

\subsubsection{HICKERSON LAKE AREA}

Hickerson Lake lies within a landslide-dammed glacial valley (Detterman and Hartsock, 1966) approximately $5 \mathrm{~km}$ north of Chinitna Bay, with nearby topographic relief locally exceeding $1,000 \mathrm{~m}$ (fig. 1). Naknek
Formation strata near the lake dip gently $\left(22-27^{\circ}\right)$ southeastward and are discontinuously exposed along the lake's northeastern and southwestern shorelines as well as in the surrounding valleys, ridges, and peaks (fig. 3A). The large-scale stratigraphic architecture of the Naknek Formation southwest of Hickerson Lake was preliminarily reported by Herriott and others (2015a).

A geologic mapping traverse on the southwestern shore of Hickerson Lake revealed a clast-supported cobble conglomerate greater than $5 \mathrm{~m}$ thick, with outsized clasts up to approximately $80 \mathrm{~cm}$ (figs. 5 and 6). Clasts include rounded diorite, mafic volcanic/greenstone, mafic intrusive, and commonly angular dark brown siltstone. This boulder-bearing conglomerate constitutes a channel-form sediment body with a sharp, erosional base (fig. 5B) that onlaps and immediately overlies a 98-m-thick succession of thin- to medium-bedded, sandy siltstone and subordinate sandstone that thickens to the west and is mappable as $\mathrm{Jns}_{1}$ (fig. 6); the dark brown siltstone clasts are lithologically consistent with the immediately underlying $\mathrm{Jns}_{1}$. The conglomerate is overlain by an approximately 200 -m-thick, thin- to verythick-bedded arkosic sandstone and siltstone interval, with locally common intrabasinal sedimentary clasts that are also lithologically similar to Jns 1 . Although outcrops are limited due to vegetative cover, strata in this interval are commonly channelized, onlap $\mathrm{Jns}_{1}$, and mappable as $\mathrm{Jns}_{2}$ (fig. 6). Farther along the lakeshore to the southeast lies a gray-weathering, cliff-forming, tens-of-meters-thick, amalgamated, arkosic sandstone package with prominent, sharp-based, channel-form stratal geometries that onlap $\mathrm{Jns}_{2}$ (fig. 6, leftmost shoreline).

The Snug Harbor-Pomeroy contact is mapped at the base of the cliff-forming arkoses, which are identified as $J_{n p}$ (fig. 6). Extending this contact to the west, the surface is in a stratigraphically higher position near peak 3140 (fig. 3A), where an unusually thick ( 500 m) Snug Harbor section occurs (fig. 6C) (compare to Detterman and Hartsock, 1966; Herriott and Wartes, 2014). Aerial reconnaissance and limited examination of precipitously steep outcrops indicated that Snug Harbor strata cropping out below peak 3140 comprise dominantly thin, tabular beds of fine-grained lithologies, although subordinate thick beds of sandstone are present. The difference in total Snug Harbor thickness across figure 6 suggests approximately $200 \mathrm{~m}$ of lithostratigraphic relief 
on the top of the member between peak 3140 and Hickerson Lake, where $\mathrm{Jns}_{1}$ and $\mathrm{Jns}_{2}$ combined are approximately $300 \mathrm{~m}$ thick. Relief along this surface is occupied by the arkosic, channel-form strata of Jnp 1 that onlap Snug Harbor (Jns 2 and undifferentiated Jns). Additionally, our outcrop- to mountain-scale observations of onlapping stratal terminations of $\mathrm{Jns}_{2}$ and $\mathrm{Jnp}_{1}$ channel bodies demarcate segments of a seismic-scale master erosion surface that exhibits approximately $400 \mathrm{~m}$ of stratigraphic relief and diminishing gradient upsection (fig. 6, orange long-dashed line), illustrating notable similarities in facies stacking relations of $\mathrm{Jns}_{1}$, $\mathrm{Jns}_{2}$, and $\mathrm{Jnp}_{1}$ between the Hickerson Lake southwest and Chisik Island localities (compare figs. 4 and 6).

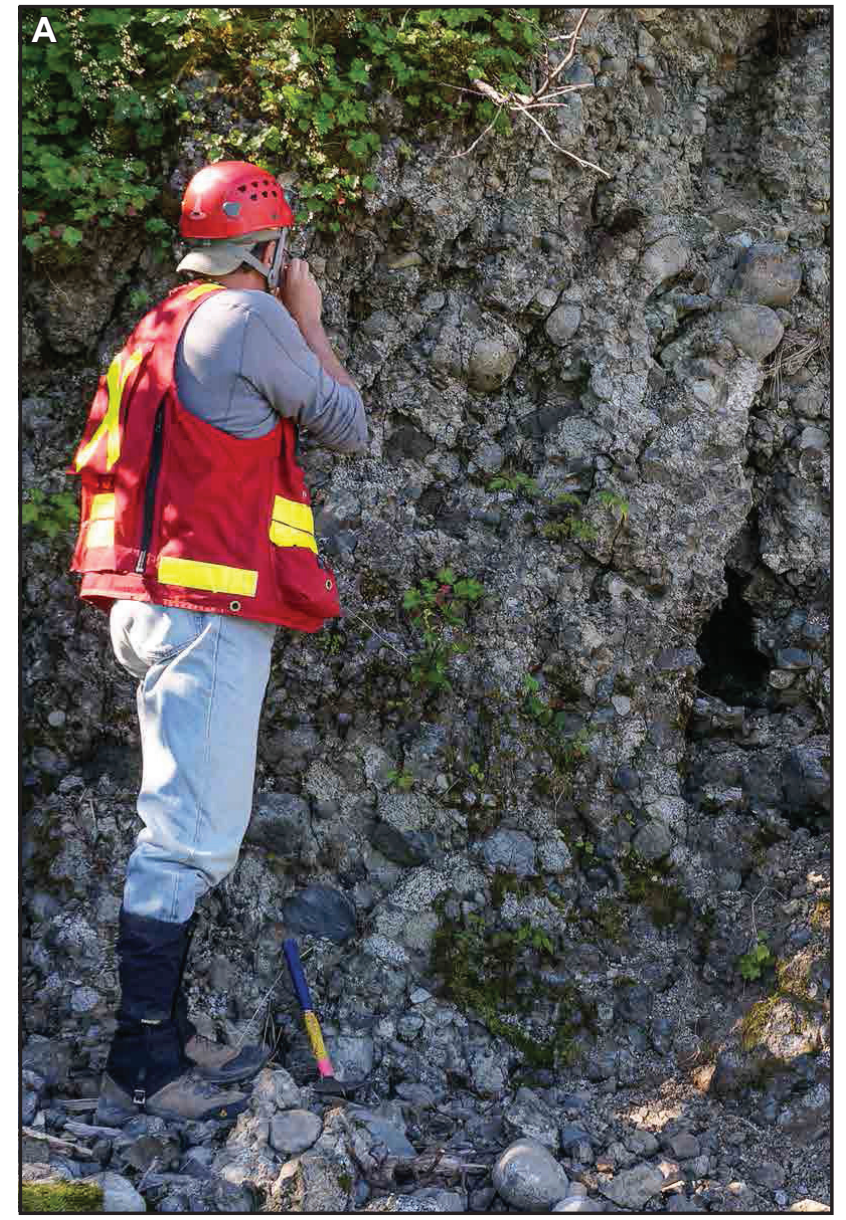

Observations of the Snug Harbor and Pomeroy stratigraphy immediately northeast of Hickerson Lake are hampered by limited lake-level exposures, but stratigraphic context is provided by outcrops of the lower sandstone member, which correlates well to the tightly constrained lower sandstone-Snug Harbor contact along the southwest lakeshore (fig. 3A). Directly above this outcrop of the uppermost lower sandstone is a 161-m-thick, recessive, covered interval overlain by a greater-than-40-m-thick succession of very-thick-bedded, boulder-bearing, pebble and cobble conglomerate with subordinate lenses of sandstone (fig. 7). Discontinuous exposures above this conglomeratic package suggest dominantly arkosic strata overlie the figure $7 \mathrm{~B}$

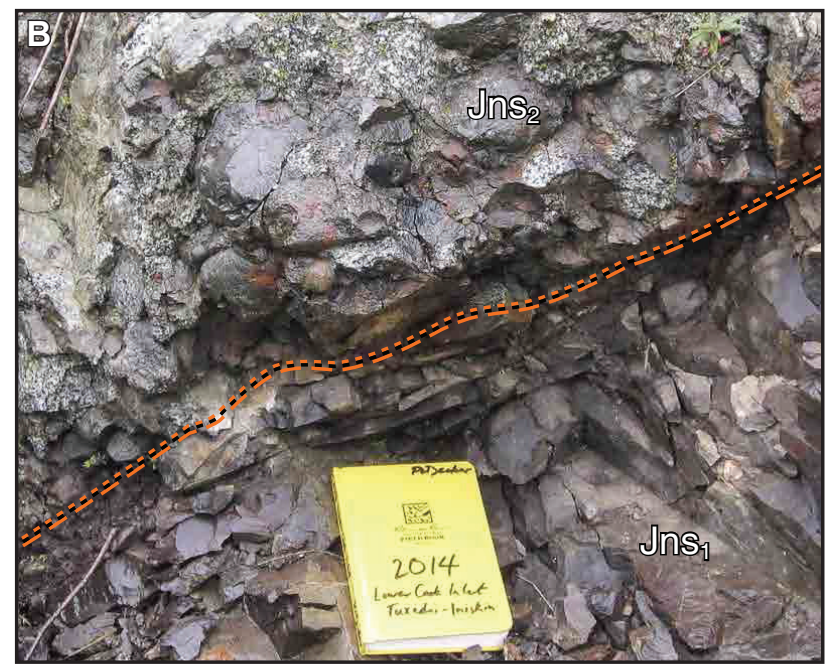

Figure 5. Photographs of the $>5$-m-thick, boulder-bearing cobble conglomerate in the Snug Harbor Siltstone Member (Jns 2 ), southwest shore of Hickerson Lake (fig. 1). (A) The chiefly rounded-cobble conglomerate is disorganized, clast supported, and lacks evident internal stratification. Geologist for scale. Photograph by M.A. Wartes. (B) View of sharp, erosional base (orange short-dashed line) of the channel-form cobble conglomerate bed (Jns 2 ), which overlies fine-grained strata typical of Snug Harbor (Jns ${ }_{1}$ ). Larger-scale stratigraphic context is in figure 6 . Notebook is $12 \times 19 \mathrm{~cm}$ for scale. Line symbology after figure 4. Photograph by P.L. Decker.

Figure 6 (opposite page). Oblique aerial view southwestward of peak 3140 area (fig. 3B), with the southwestern shoreline of Hickerson Lake in the foreground. Key stratigraphic relations in the Snug Harbor Siltstone (Jns) and Pomeroy Arkose (Jnp) Members (and subscripted divisions) are discussed in the text. (A) Oblique aerial photograph. (B) Photogeologic rendition. (C) Line-drawing rendition. View toward center of photograph is generally strike parallel, with beds dipping $20^{\circ}$ southeastward (toward left of photograph). See stratigraphic thicknesses for sense of scale. Figure modified from Herriott and others (2015a). Photograph by T.M. Herriott. Stratigraphic units (ascending order): Inss = lower sandstone member, Naknek Formation; Ins = Snug Harbor Siltstone Member, Naknek Formation; Jnp = Pomeroy Arkose Member, Naknek Formation. 

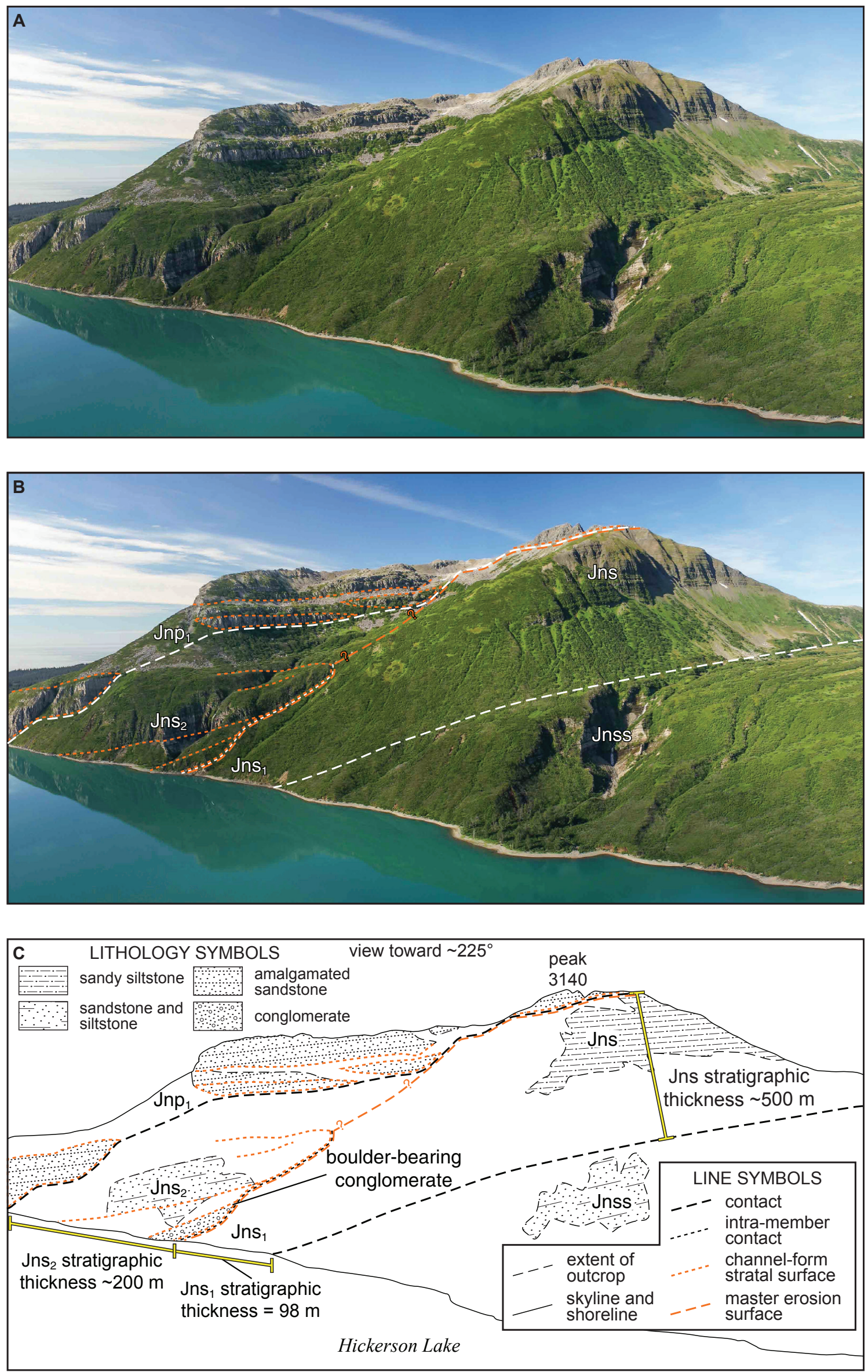

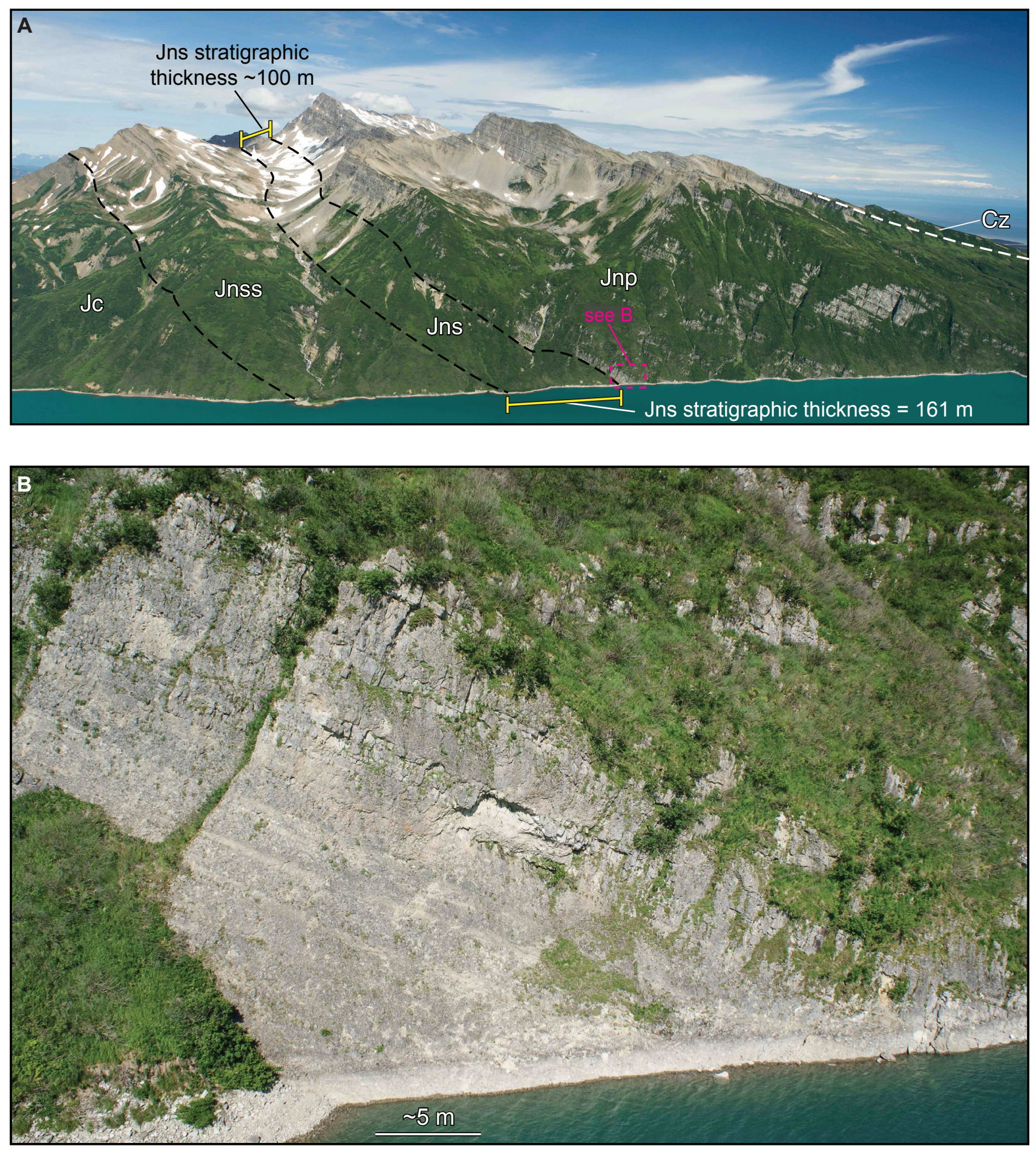

Figure 7. Photographs of the area northeast of Hickerson Lake. (A) Oblique view northeastward, with the northeastern shore of Hickerson Lake in the foreground. See text for discussion of stratigraphic thicknesses and map unit relations. View toward center of photograph is approximately strike parallel, with beds dipping $\sim 25^{\circ}$ southeastward (toward right of photograph). See stratigraphic thicknesses for sense of scale; note also that Snug Harbor Siltstone Member (Jns) at ridgeline is 3 km north-northeast of Snug Harbor section at shoreline. (B) Oblique aerial view northeastward of the base of Pomeroy Arkose Member along the northeastern shore of Hickerson Lake; see area noted by magenta dashed line in A for reference to field of view. This well-exposed basal section of the Pomeroy is $>40 \mathrm{~m}$ thick and comprises a channelized and tabular-bodied conglomerate package with subordinate sandstone; this interval is recognized as Jnp ${ }_{1}$ Photographs by T.M. Herriott. Stratigraphic units (ascending order): Jc = Chinitna Formation; Jnss = lower sandstone member, Naknek Formation; Ins = Snug Harbor Siltstone Member, Naknek Formation; Inp = Pomeroy Arkose Member, Naknek Formation; Cz = Cenozoic strata. 
outcrop. We map the Snug Harbor-Pomeroy contact at the base of the conglomerate section (Herriott and Wartes [2014] reported similar basal Pomeroy facies in the Iniskin Bay area), limiting the Snug Harbor to the 161-m-thick covered interval (fig. 7A). Although stratification is somewhat enigmatically expressed in the basal Pomeroy conglomerate of figure 7B, channel-forms and tabular beds are recognized, and the interval is identified as $\mathrm{Jnp}_{1}$. The ridgeline about $3 \mathrm{~km}$ north-northeast of figure $7 \mathrm{~B}$ hosts an approximately 100-m-thick Snug Harbor stratigraphy (fig. 7A), which is approximately $400 \mathrm{~m}$ thinner than the Snug Harbor north of peak 3140 (fig. 6C) that lies about $5 \mathrm{~km}$ to the southwest (fig. 3A). Vegetative and talus cover are common along the northeast lakeshore-to-ridgeline trend, but the stratigraphic thickness of Snug Harbor must remain relatively thin throughout this area as constrained by outcrops of the lower sandstone and Pomeroy Arkose members (fig. 7A).

Excellent exposures of the Snug Harbor and lower Pomeroy stratigraphy occur approximately $3-4 \mathrm{~km}$ to the north-northeast of Hickerson Lake, where $\mathrm{Jns}_{1}$, $\mathrm{Jns}_{2}$, and $\mathrm{Jnp}_{1}$ are mapped in two cirque headwalls (fig. 8; also fig. 3A). The cirque immediately beyond the figure $7 \mathrm{~A}$ ridgeline reveals channelized, conglomeratebearing successions of $\mathrm{Jns}_{2}$ and $\mathrm{Jnp}_{1}$ that onlap $\mathrm{Jns}_{1}$ and $\mathrm{Jns}_{2}$, respectively (fig. $8 \mathrm{~B}$ ). $\mathrm{Jns}_{2}$ sandstones are distinctly browner-weathering than the overlying grayweathering sandstones of $\mathrm{Jnp}_{1}$ (fig. 8B-D). Additionally, $\mathrm{Jns}_{2}$ appears to be mostly conglomerate to the southwest (rightmost $\mathrm{Jns}_{2}$ of fig. $8 \mathrm{~B}$ ), whereas conglomerate constitutes only a subordinate component of $\mathrm{Jns}_{2}$ along the ridgeline between the two cirques (fig. $8 \mathrm{~B}-\mathrm{D}$ ). The 50 -m-thick $\mathrm{Jns}_{1}$ on the common ridgeline/skyline of the figure 8 photographs is overlain by $26 \mathrm{~m}$ of $\mathrm{Jns}_{2}$, and the $\mathrm{Jns}_{1}-\mathrm{Jns}_{2}$ and $\mathrm{Jns}_{2}-\mathrm{Jnp_{1 }}$ erosional contacts each cut across tens of meters of stratigraphy in the two headwall exposures, resulting in apparent eastward or northeastward thickening wedges of the Snug Harbor units (fig. 8B and C). However, the cumulative Snug Harbor is somewhat thicker to the west-southwest, where the undifferentiated member thickness is approximately $100 \mathrm{~m}$ (fig. 7A; lower-right of fig. 8B). These thickness relations indicate locally variable morphology along the erosional contacts. A master erosion surface, as delineated by $\mathrm{Jns}_{2}$ channel-forms that onlap and cut into $\mathrm{Jns}_{1}$, lies at the base of the channelized $\mathrm{Jns}_{2}-\mathrm{Jnp}_{1}$ stratigraphy and is readily mapped across the figure $8 \mathrm{~B}$ headwall. The stratigraphic architecture and facies relations at these cirques are broadly similar to and consistent with our observations in the area southwest of Hickerson Lake (fig. 6) and at Chisik Island (fig. 4).

\subsubsection{MOUNT POMEROY AREA}

Mount Pomeroy (2,385 feet) lies along a prominent cuesta that extends between Iniskin and Oil bays (fig. 1). Snug Harbor Siltstone and Pomeroy Arkose Members in the area dip gently $\left(13-29^{\circ}\right)$ southward and are exposed in steep north-facing slopes and cliffs (fig. 3B). Herriott and Wartes (2014) briefly reported atypical map-scale stratigraphic relations between these two members in the Mount Pomeroy area.

Geologic mapping of Mount Pomeroy indicates that its northern flanks comprise Snug Harbor strata (fig. 9A; Herriott and Wartes, 2014). Along strike approximately $0.6 \mathrm{~km}$ west of Mount Pomeroy, channel-form strata

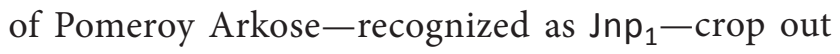
in the north-facing cliff and onlap the Snug Harbor along a sharp erosion surface (fig. 9B and C). Farther along strike to the west, amalgamated arkose and conglomerate constitute the entire cliff face, with the Snug Harbor-Pomeroy contact cutting farther downsection westward along the base of the cliff (fig. 10). The arkosic, cliff-forming package of $\mathrm{Jnp}_{1}$ extends for approximately $4 \mathrm{~km}$ southwest of Mount Pomeroy to the east shore of Iniskin Bay and continues to host channel-form sediment bodies (fig. 10). The Snug Harbor recessively underlies the Pomeroy Arkose west and southwest of Mount Pomeroy (figs. 9B and $\mathrm{C}$ and 10). At Iniskin Bay, sharp- and erosive-based, channelized, very-thick-bedded arkosic sandstones and disorganized, boulder-bearing conglomerates of $\mathrm{Jnp}_{1}$ are common (fig. 11) and onlap the underlying Snug Harbor (fig. 10B). Notably, the Snug Harbor is approximately $425 \mathrm{~m}$ thick at Mount Pomeroy, but thins by approximately $175 \mathrm{~m}$ to the west, measuring $252 \mathrm{~m}$ thick at Iniskin Bay (fig. 10B). The only known Snug Harbor stratigraphy that is comparable to the Mount Pomeroy area thickness is the approximately 500-m-thick succession near peak 3140 (fig. 6C).

Our geologic mapping (fig. 3B) follows the lithostratigraphic surfaces reported above (figs. 9 and 10) and is generally consistent with early work by Kirschner and Minard (1949) and Hartsock (1954), although the stratigraphic implications of the map pattern were not 

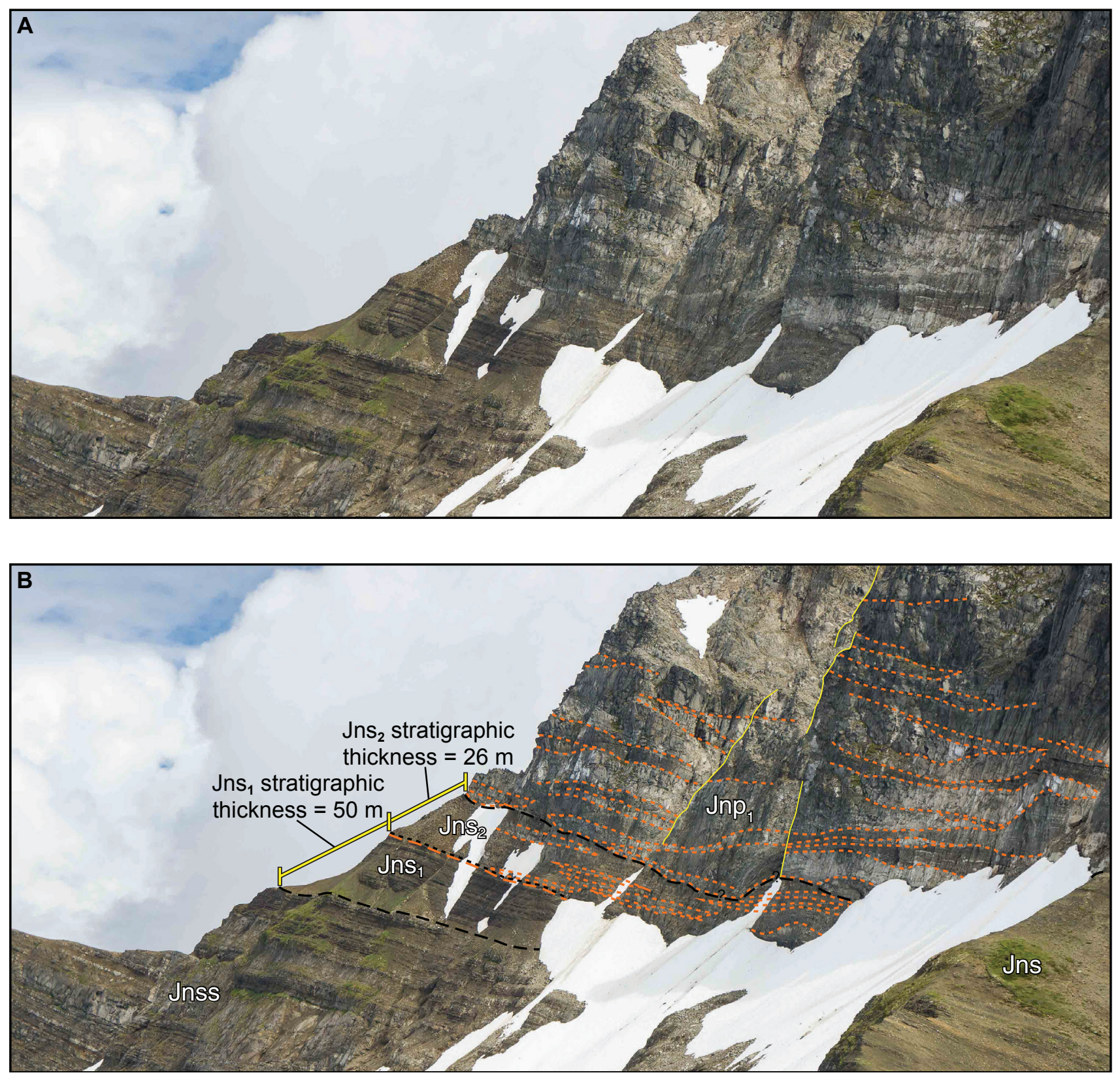

Figure 8 (above and opposite page). Photographs of two cirque headwalls 3-4 km northeast of Hickerson Lake. (A) Oblique view northeastward of cirque headwall (labeled NW cirque in fig. 3A) immediately beyond figure 7A skyline. Photograph by T.M. Herriott. (B) Photogeologic rendition of A. Channel-form stratal surfaces (orange short-dashed lines) are common in Jns, and Jnp ; the Jns -Jns $_{2}$ contact (orange long-dashed line at center left of figure) defines a master erosion surface comparable to the surfaces mapped in figures 4, 5B, and 6. Jns at lower right is the upper part of the 100-m-thick Snug Harbor section along the ridgeline of figure 7A. Thin yellow lines delineate steep ridges that disrupt perspectives of sediment body continuity in the cliff face. View is approximately strike parallel, with beds dipping $26-28^{\circ}$ southeastward (toward right of photograph). See stratigraphic thicknesses for sense of scale; the headwall is $\sim 450 \mathrm{~m}$ wide at the base of Pomeroy. (C) Oblique aerial view southwestward of cirque headwall (labeled NE cirque in fig. 3A) $\sim .8 \mathrm{~km}$ beyond 100-m-thick Snug Harbor section in figure 7A and immediately beyond skyline of A and B. Note the excellent expression of $\mathrm{Jns}_{2}$ facies at left, including tabular-bedded siltstone and arkose as well as channelized arkose; channel-form sediment bodies of Jnp ${ }_{1}$ onlap $\mathrm{Jns}_{2}$. View is nearly strike parallel, with beds dipping $27-28^{\circ}$ southeastward (toward left of photograph). Photograph by M.A. Wartes. (D) Outcrop denoted by magenta arrow in C. View of channelized pebbly sandstone and cobble conglomerate at base of Jns 2 . $\mathrm{Jns}_{2}$ arkoses are tannish-brown-weathering, whereas overlying Pomeroy arkoses (B and $\mathrm{C}$ ) are distinctly gray-weathering, likely reflecting upsection diminishment of mud in the sandstones. Pencil (in magenta ellipse) is $14 \mathrm{~cm}$ long for scale. Photograph by T.M. Herriott. Additional line symbology after figures 4 and 6 . Stratigraphic units (ascending order): Inss = lower sandstone member, Naknek Formation; Ins = Snug Harbor Siltstone Member, Naknek Formation; Inp = Pomeroy Arkose Member, Naknek Formation. 

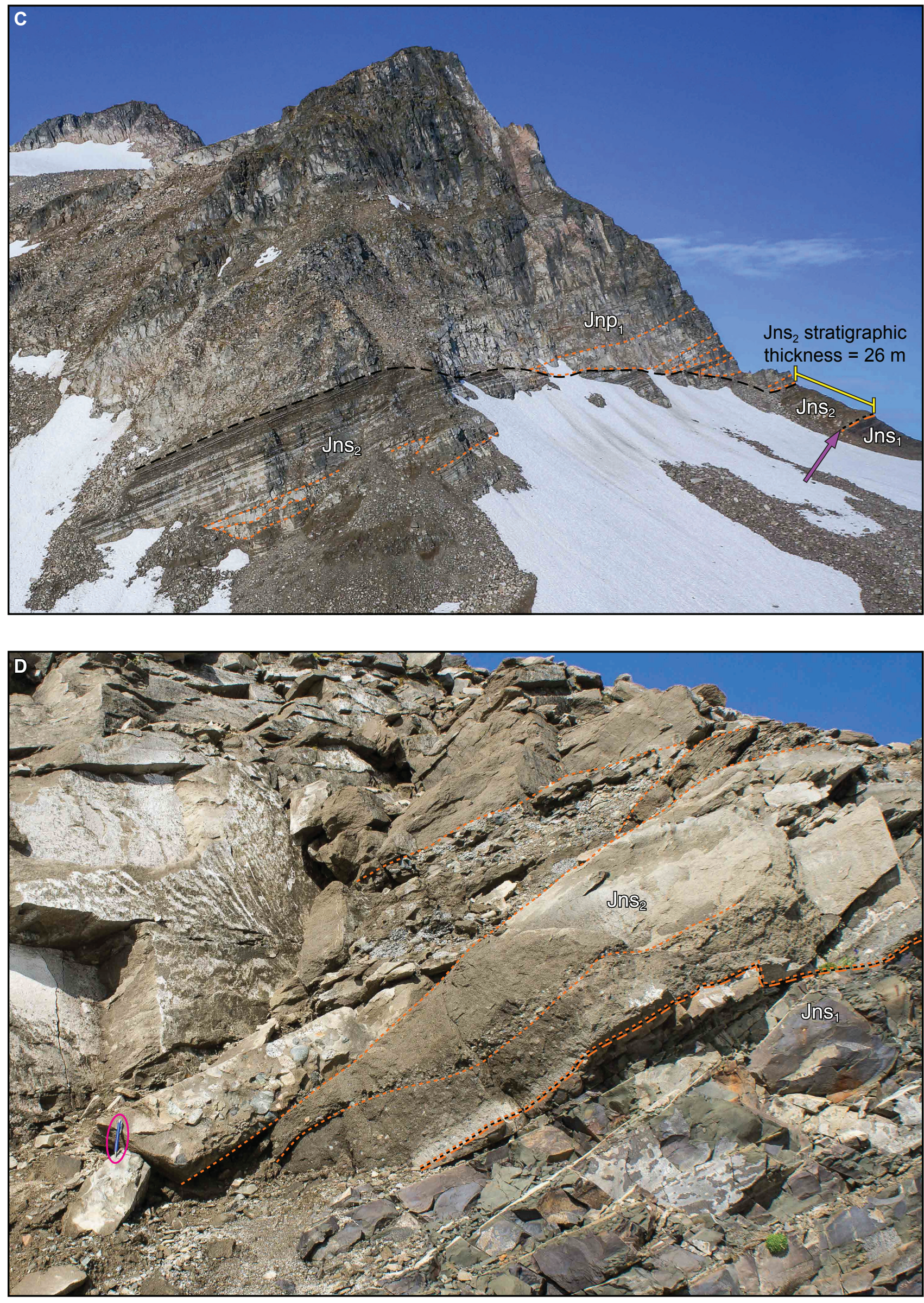

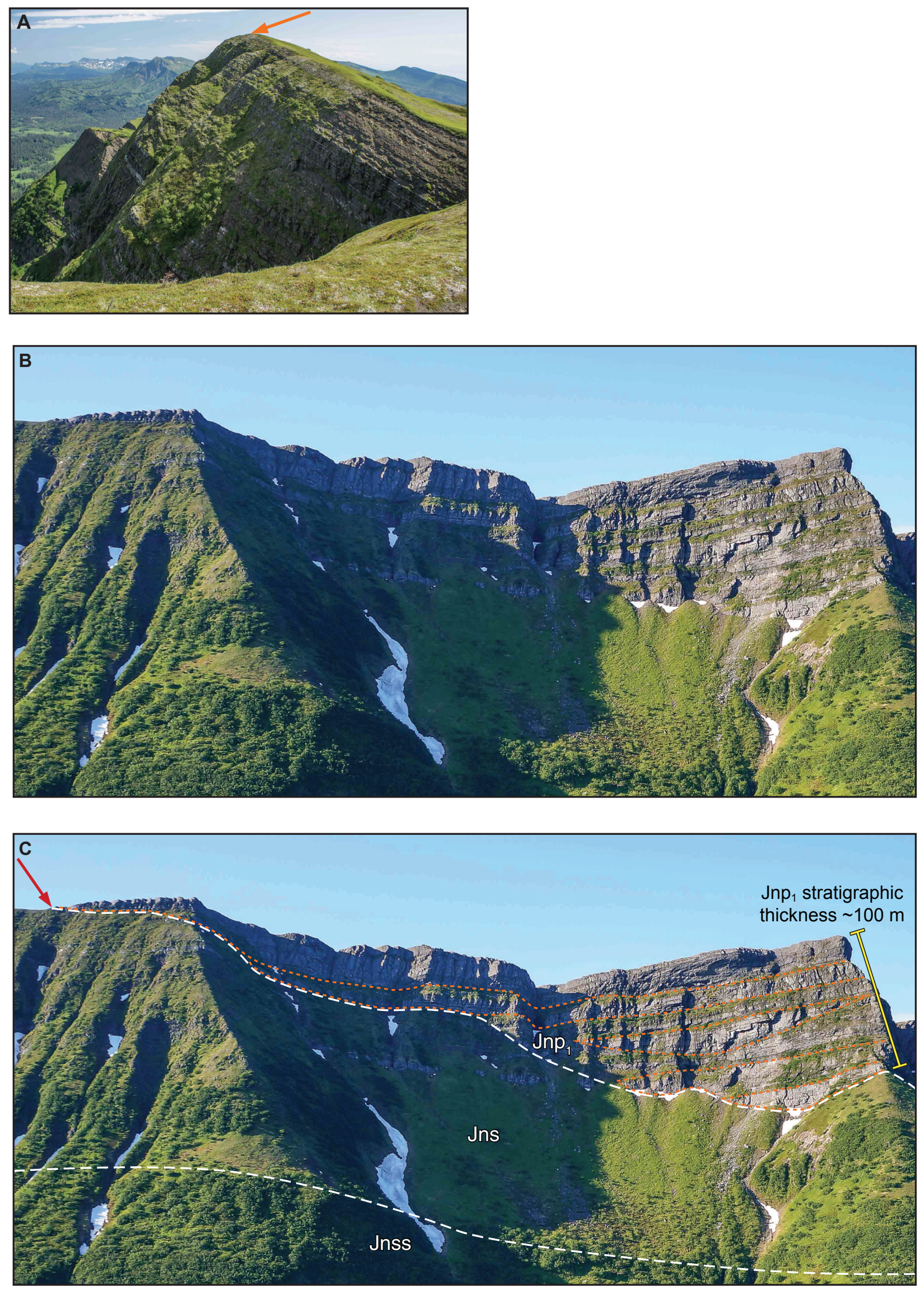
discussed until recently (Herriott and Wartes, 2014). The new mapping and stratigraphic thickness determinations indicate a westward-thickening package of channelized Pomeroy Arkose $\left(\mathrm{Jnp}_{1}\right)$ that occupies approximately $175 \mathrm{~m}$ of relief on a seismic-scale surface that cuts across the underlying Snug Harbor, which thickens eastward into a remarkably thick $(\sim 425$ $\mathrm{m})$ succession near Mount Pomeroy (fig. 10). The member-scale stratigraphic architecture of the Snug Harbor Siltstone and Pomeroy Arkose along the Mount Pomeroy-to-Iniskin Bay trend is broadly similar to the stratigraphic relations documented near Chisik Island and Hickerson Lake approximately $70 \mathrm{~km}$ and $40 \mathrm{~km}$ to the northeast, respectively (fig. 1). Interpretations and further discussion of the stratigraphic architecture in these three areas are presented in the following section.

\subsection{Interpretations and Discussion- Deep-Water Canyons and Associated Stratigraphic Elements}

The Snug Harbor Siltstone and Pomeroy Arkose Members' lithologies, bedding geometries, onlap relations, and marked changes in stratigraphic thicknesses reveal depositional systems with large seafloor pathways that transported and accumulated sediment in deep water ${ }^{3}$. The seismic-scale exposures in the Chisik Island, Hickerson Lake, and Mount Pomeroy areas are interpreted as the record of processes, products, and associations with deep-water canyons (fig. 12), which we define as broad (fill is kilometers wide), deep (fill is hundreds of meters thick), erosive-based, slope-associated conduits for transport of mud, sand, and gravel in deep-marine environments (compare with Shepard, 1981; Pickering and others, 1989; Reading and Richards, 1994; Galloway and Hobday, 1996; Galloway, 1998; Richards and others, 1998; Posamentier and Allen, 1999; Prather, 2003; Weimer and Slatt, 2007; Di Celma, 2011; Jobe and others, 2011; Williams and Graham, 2013). Scale alone is commonly insufficient to distinguish between slope channels and canyons-although the latter are in general larger than the former-but it is the markedly erosional character and complex, composited, and long-lived evolution of marine canyons that differentiate them from deep-water channels (Galloway, 1998) that themselves form part of the process-response framework of canyon-associated depositional systems. The recognition of seismic-scale deep-water depositional systems elements such as canyons in outcrop is not common (see discussion by Di Celma, 2011; see also Mutti and Normark, 1987), but documentation of these and related features is a key aspect to determining paleophysiography (Posamentier and Allen, 1999) and understanding basin-scale depositional cycles (Miall, 2010).

Marine canyons form where sufficient bathymetric gradients, and thus gravitational potential, exist for mass wasting and erosive sediment gravity flows to incise the seafloor (for example, Shepard, 1981; Pickering and others, 1989; Galloway, 1998; Normark and Carlson, 2003). Where these conditions persist, long-lived conduits for sediment transport from shelfal to deep-water environments are established (see reviews by Galloway and Hobday, 1996; Weimer and Slatt, 2007). Along depositionally constructional basin margins, canyons are commonly incised into

\footnotetext{
${ }^{3}$ Deep-water marine settings are typically at greater than $200 \mathrm{~m}$ water depth (for example, Galloway and Hobday, 1996). However, our emphasis in this paper is that deep-water environments are below storm wave base and lie basinward of a shelf-slope break (if one is present). This emphasis is process-response focused, with sediment transport and deposition in deep-water realms governed at least in part by gradient-driven processes such as sediment gravity flows.
}

Figure 9 (opposite page). Photographs of the Mount Pomeroy area. (A) Oblique view eastward of Mount Pomeroy (orange arrow), which comprises chiefly thin-bedded siltstone with subordinate thicker-bedded and arkosic sandstone. This exposure is the upper part of a very thick ( $425 \mathrm{~m}$ ) Snug Harbor succession; the only comparable Snug Harbor thickness elsewhere in the study area is observed west of Hickerson Lake (section 2.2.2). View is approximately strike parallel, with beds dipping $30^{\circ}$ southward (toward right of photograph; fig. 3B); note that the uppermost beds of Snug Harbor lie to the right of the field of view of this photograph along the dip-slope south of Mount Pomeroy. Figure modified from Herriott and Wartes (2014). Photograph by T.M. Herriott. (B) Oblique aerial view southward of the ridge extending west of Mount Pomeroy, which lies $\sim 0.6 \mathrm{~km}$ along strike to the east (left) of this field of view. Photograph by M.A. Wartes. (C) Photogeologic rendition of B. Channel-form sediment bodies of Jnp $p_{1}$ onlap Snug Harbor along a sharp, erosional contact that cuts across $\sim 100 \mathrm{~m}$ of stratigraphy in this $\sim 0.7-\mathrm{km}$-wide field of view. View is approximately dip parallel. See Jnp ${ }_{1}$ stratigraphic thickness for sense of scale. Red arrow marks the easternmost extent of the Snug Harbor-Pomeroy contact on this cliff face (see also fig. 10). Additional line symbology after figure 6. Stratigraphic units (ascending order): Inss = lower sandstone member, Naknek Formation; Ins = Snug Harbor Siltstone Member, Naknek Formation; Inp = Pomeroy Arkose Member, Naknek Formation. 

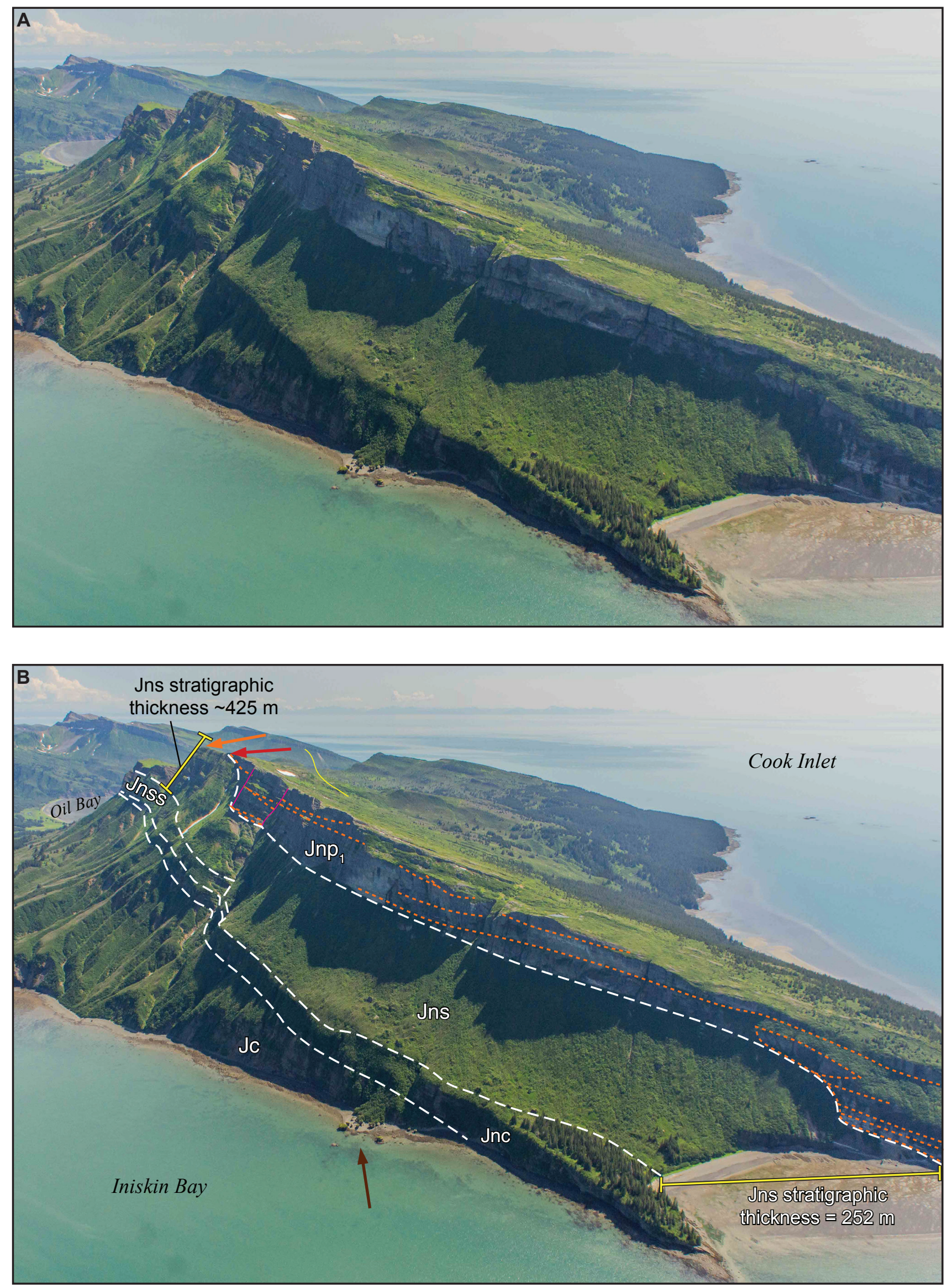

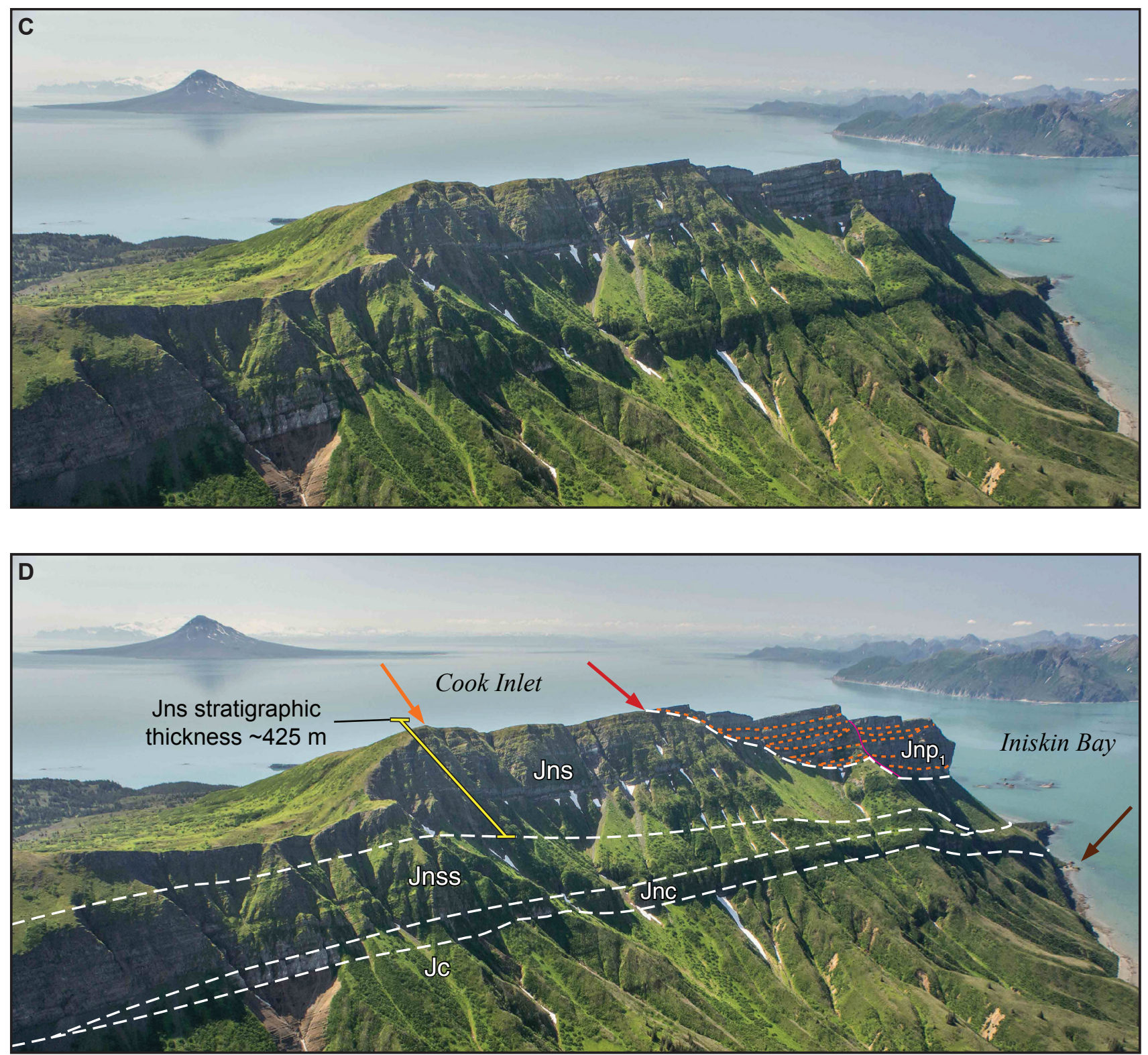

Figure 10 (opposite page and above). Oblique aerial photographs depicting stratigraphic relations in the Snug Harbor Siltstone (Jns) and Pomeroy Arkose (Jnp) Members of the Mount Pomeroy area between Iniskin and Oil bays (figs. 1 and 3B). (A) View eastward of the Mount Pomeroy (orange arrow in B) area uplands. (B) Photogeologic rendition of A. The easternmost extent of Pomeroy Arkose strata (Jnp ${ }_{1}$ ) in the cliff face is marked by the red arrow (see also fig. 9C). Snug Harbor extends for $1 \mathrm{~km}$ on the Iniskin Bay coastline (for sense of scale) and is demonstrably thinner (by $175 \mathrm{~m}$ ) there than at Mount Pomeroy. View is nearly strike parallel, with beds dipping $25^{\circ}$ southward (toward right of photograph). (C) View southwestward of the Mount Pomeroy (orange arrow in D) area uplands. (D) Photogeologic rendition of C. The Snug Harbor stratigraphy at Mount Pomeroy lies along strike from lithologically distinct Pomeroy strata (Jnp $\left.p_{1}\right)$ in the cliffs to the west (right). The lithostratigraphic contact between these two units cuts across the stratigraphy (downsection from red arrow [see also figs. 9C and 10B] toward right of photograph); see text for further discussion. View is oblique to strike (east) and dip of bedding ( $25^{\circ}$ south). See Jns stratigraphic thickness for sense of scale. D is modified from Herriott and Wartes (2014). For additional geographic reference, The Toadstools (fig. 3B) are at the brown arrows of B and D. Thin magenta lines in B and D delineate steep ridges that disrupt perspectives of sediment body continuity in the cliff face. Additional line symbology after figure 6. Photographs by T.M. Herriott. Stratigraphic units (ascending order): Jc = Chinitna Formation; Jnc = Chisik Conglomerate Member, Naknek Formation; Inss = lower sandstone member, Naknek Formation; Jns = Snug Harbor Siltstone Member, Naknek Formation; Inp = Pomeroy Arkose Member, Naknek Formation. 
progradational slope successions (fig. 12; Galloway, 1998). Deep-water canyon fills range from mud-dominated to coarse-grained, high net (sand and gravel) to gross (mud, sand, and gravel) deposits (for example, Reading and Richards, 1994; Posamentier and Allen, 1999; Posamentier and Kolla, 2003; Jobe and others, 2011). The caliber of sediment supplied to the system, seafloor gradient, and sediment gravity flow parameters are among the factors that influence the balance of bypass versus deposition in deep-water settings (Stevenson and others, 2015; also section 3), directly impacting the lithologic character of canyon fill. Muddominated canyon systems may yield poor outcrop potential, with many of the best exposures of ancient deep-water canyons comprising coarse-grained, ero-
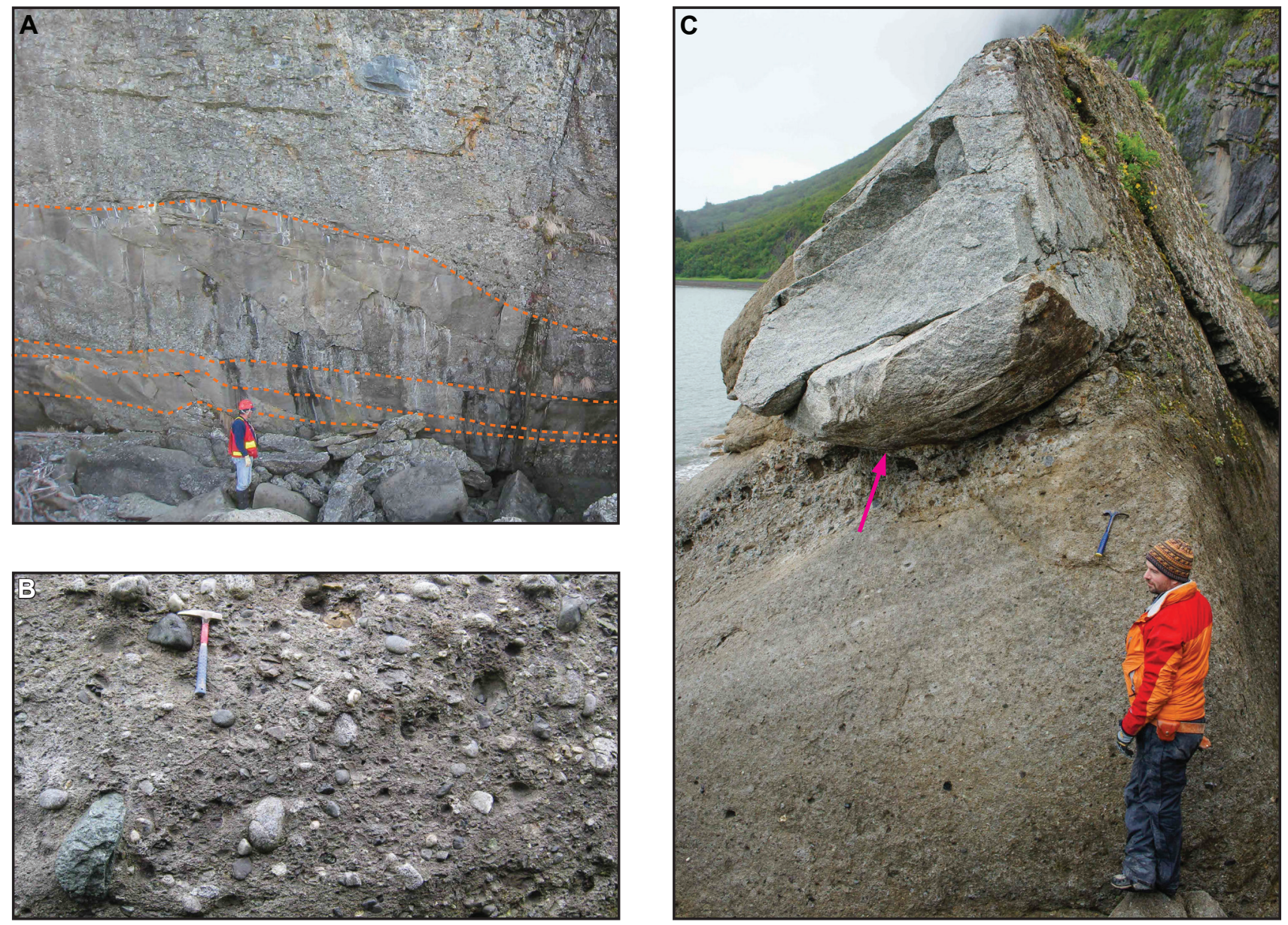

Figure 11. Photographs of $\mathrm{Jnp}_{1}$ arkose and conglomerate at Iniskin Bay. (A) Sharp juxtaposition of lithofacies and relief along channelform stratal surfaces (orange short-dashed lines) reflect a highly erosive setting with cut-and-fill-style sedimentation characterized by disorganized conglomerate and sandstone. Geologist for scale. Photograph by M.A. Wartes. (B) Disorganized, very-thick-bedded, poorly sorted, matrix-supported conglomerate. Clasts are predominantly arc-derived diorite and mafic metavolcanic lithologies. Hammer head is $16 \mathrm{~cm}$ long for scale. From Wartes and others (2013). Photograph by M.A. Wartes. (C) A >2 m (apparent long dimension) diorite boulder

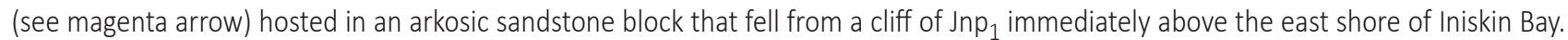
This outsized clast suggests high-energy, highly competent, channelized flow conditions that are consistent with our observations of Jnp 1 . Geologist for scale. Photograph by T.M. Herriott. 
slopes-settings with gravity-driven erosional potential that are prone to bypass-transition downdip to lower-gradient base-of-slope and basin-floor settings, where depositional systems become increasingly defined by aggradation (fig. 12) (for example, Mutti and Normark, 1987; Galloway, 1998; Wynn and others, 2002). Through time, deposition along a previously erosional reach of a deep-water channel profile may lower the gradient and render increasingly aggradational processes at that locality (for example, Hodgson and others, 2016).

The Chisik Island, Hickerson Lake, and Mount Pomeroy canyons are interpreted as integral components of a source-to-sink sediment dispersal system, linking shelfal to basin-floor environments near the northwestern margin of the Cook Inlet forearc basin during late Oxfordian(?)-early Kimmeridgian time. Transport of sediment through canyon-associated depositional systems led to the accumulation of dominantly coarse-grained strata at base-of-slope to basin-floor settings; sediment that was not bypassed to more distal sites accumulated along canyon axes. We recognize $\mathrm{Jns}_{1}$ as pre-canyon establishment strata, $\mathrm{Jns}_{2}$ and $\mathrm{Jnp}_{1}$ as the record of canyon filling, overthickened Jns deposits as large-scale, conduit-bounding levee successions, and $\mathrm{Jnp}_{2}$ as distributary lobe deposits that accumulated beyond canyon mouths. Observations

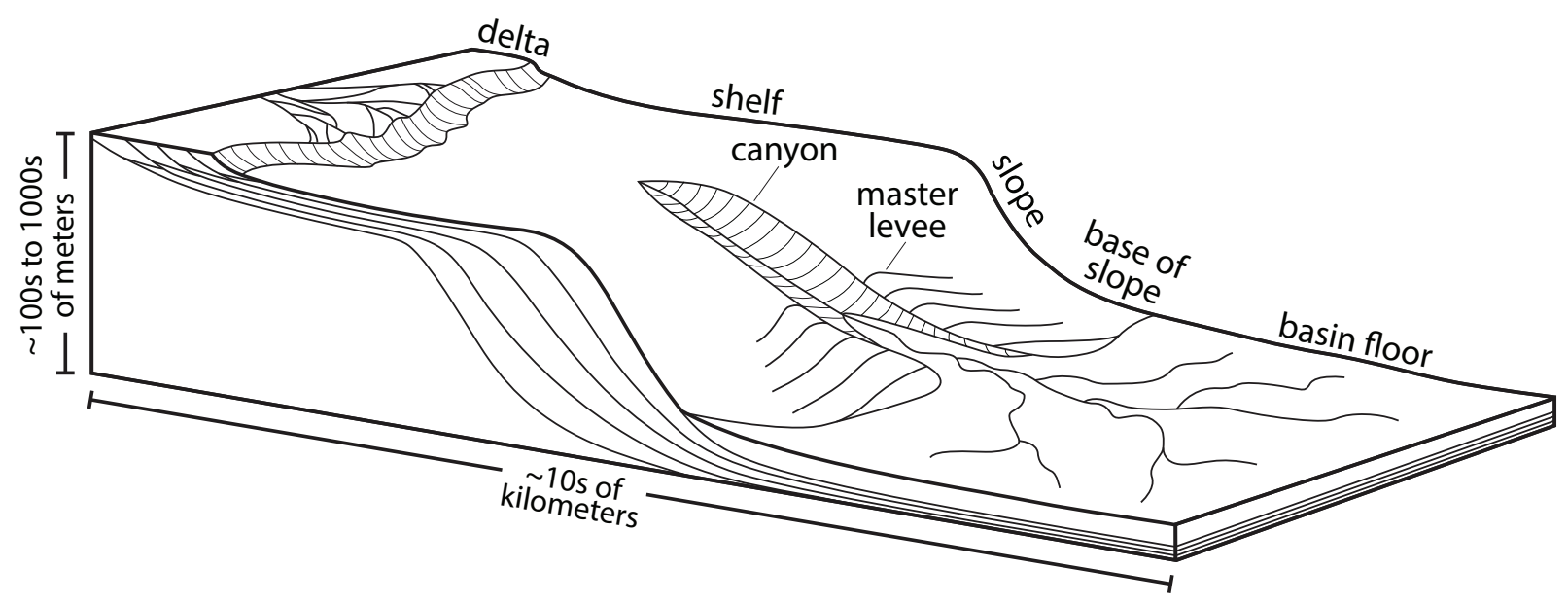

Figure 12. Schematic block diagram of a generalized marine delta-shelf-slope-base-of-slope-basin-floor depositional profile, with a submarine canyon incised into slope strata and bounded by master levees along its lower reaches near the base of slope. The shallow- to deep-water transition lies at the shelf-slope break; the slope gradient is exaggerated for clarity (note generalized vertical and horizontal scales). The deep-water canyons and associated stratigraphic elements described in this paper are interpreted as the record of environments at and proximal to the base of slope. Figure modified from Pickering and others (1989), Posamentier and Kolla (2003), Posamentier and Walker (2006), and Hubbard and others (2012).

Figure 13. Schematic cross sections of confinement mechanisms for deep-water channel systems with two end members: erosional (A) and aggradational (C); a mixed erosional-aggradational case (B) represents an example that lies along a continuum for channel confinement and maintenance processes and is likely dominant in natural systems. We interpret the Naknek deepwater canyons and associated stratigraphic elements to coincide with the hybrid confinement model of $\mathrm{B}$. The focus of the current study is on canyon-scale incision surfaces and largest-scale constructional confinement elements, but note that similar relations of erosion and aggradation at channel margins occur at many scales within channelized deep-water systems (see footnote 4). Levee heights in $\mathrm{B}$ and $\mathrm{C}$ are not intended to be drawn to scale; levee growth is contemporaneous with sediment gravity flows transiting channel axes; channel-fill strata are omitted for clarity. Figure modified from Clark and Pickering (1996) and Weimer and Slatt (2007); see also Stow and Mayall (2000).

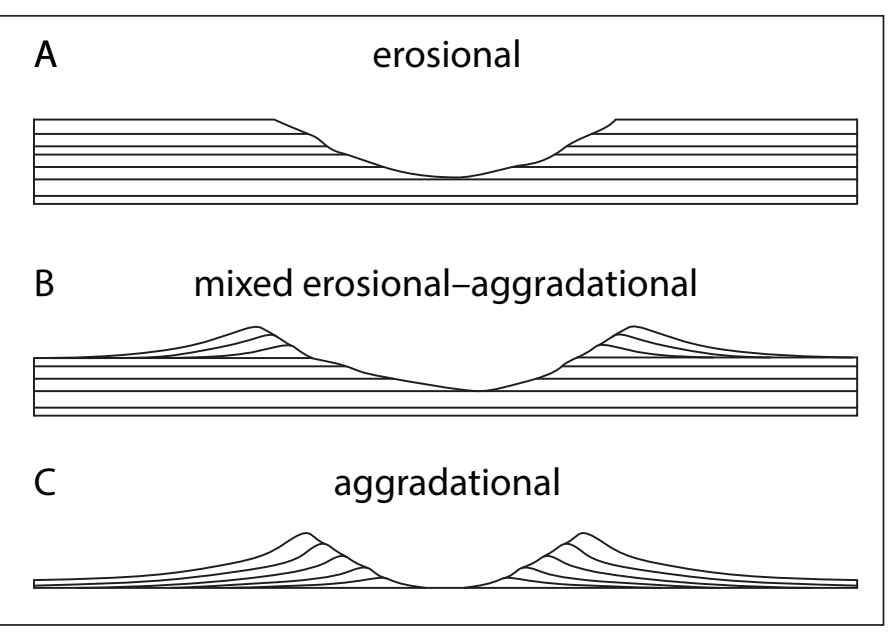


reported above permit insights into the establishment, stratigraphic evolution, morphology, and distribution of the Naknek Formation deep-water canyons.

\subsubsection{CANYON ESTABLISHMENT AND CONFINEMENT}

There are two end members for confinement of channelized deep-water depositional systems ${ }^{4}$ : (1) Erosional establishment of margins prior to filling, and (2) aggradational establishment and maintenance of leveed margins concurrent with filling (fig. 13). Between these end members lies a spectrum comprising varying degrees of erosional versus aggradational confinement (example in fig. 13B). Note that use of the term canyon in deep-water stratigraphy literature is often reserved for large, slope-incised sediment routing conduits that lack or have minimally developed bounding levees (Shepard, 1981; Weimer and Slatt, 2007; Hansen and others, 2015) and is readily applied to many modern seascapes (Normark and Carlson, 2003). However, the continuum of process-response products that characterize these deep-water settings clearly reflects dynamic, evolving depositional systems, as briefly noted above, commonly presenting difficulties in distinguishing the exact nature of confinement in large-scale ancient successions in outcrop (for example, Bain and Hubbard, 2016). Additionally, slope-associated sediment routing systems often result in stacking of end-member and transitional confinement associations in systematic patterns (for example, Galloway, 1998; Hodgson and others, 2016). In this context, we employ canyon in this paper to refer to a deep-water sediment routing conduit that, at its maximum incision state, would have likely met a strict, erosion-bound canyon definition; later transformations of canyon-associated Naknek Formation deep-water depositional systems toward more aggradational character are described below.

The Chisik Island, Hickerson Lake, and Mount Pomeroy canyons were likely established and modified by erosive sediment gravity flows, as suggested by channel-form, sharp-based, deep-water strata that onlap the canyon margins (figs. 4, 5, 6, 8, and 9; for example, compare with Mutti and Normark, 1987; Mayall and others, 2006; Di Celma, 2011; Fildani and others, 2013;
Macauley and Hubbard, 2013; Hubbard and others, 2014). Canyon-establishment processes were driven by negative deviations from the former equilibrium profiles of the Snug Harbor slope of Jns ${ }_{1}$ (section 3.3). The sharp juxtaposition of channelized canyon fillbest expressed by $\mathrm{JnS}_{2}$ and $\mathrm{Jnp}_{1}$ at the Chisik Island canyon (fig. 4) and the cirques exposures northeast of Hickerson Lake (fig. 8) -with Jns ${ }_{1}$ host strata clearly demonstrates that the canyons are in part bound by deep incisions. In other words, the lower parts of the Naknek canyons are confined by stratigraphic surfaces that delineate slope conduits that were cut into $\mathrm{Jns}_{1}$. In cross-sectional view these initial canyon incision surfaces may locally exceed $260 \mathrm{~m}$ (the typical thickness of the Snug Harbor) of relief, as suggested by the Chisik Island exposure, where the canyon floor cuts through $\mathrm{Jns}_{1}$ to the underlying lower sandstone member (fig. 4). Compaction of the stratigraphy during subsequent burial suggests even greater incisiondefined paleobathymetric relief was probable.

In addition to the incised canyon margins, the anomalously thick, canyon-adjacent Snug Harbor Siltstone Member stratigraphy at peak 3140 ( 500 m thick; fig. 6) and Mount Pomeroy ( 425 m thick; fig. 10) strongly suggest development of master-levee (in the sense of Posamentier and Kolla, 2003; equivalent to external levee in the sense of Kane and Hodgson, 2011; fig. 12) margins, constituting the upper parts of these thickened Snug Harbor successions (compare with Kane and others, 2007, 2009; Sylvester and others, 2011; Hodgson and others, 2011, 2016; Brunt and others, 2013; Morris and others, 2014). Total stratigraphic relief (post-compaction) along these master levees may approach or exceed $250 \mathrm{~m}$, as suggested by comparison of the overthickened Snug Harbor successions to the member's typical thickness of approximately $260 \mathrm{~m}$ (Herriott and Wartes, 2014). Aggradational growth of the master levees may have spanned much of the life of the canyons-potentially coinciding with both bypassprone and aggradational phases of canyon-floor channel belts (see review by Weimer and Slatt, 2007; further discussion below). Unequivocal canyon-fill to master-levee ties were not made during this study, although such correlations are commonly obscured by erosion along

\footnotetext{
${ }^{4} \mathrm{~A}$ hierarchy of architectural elements for channelized deep-water depositional systems is necessary to describe all the scales at which erosion, bypass, and deposition occur in these settings (for example, Sprague and others, 2005); however, our focus in this paper is chiefly on the master (highest rank) erosional margins of the deep-water canyons.
} 
the interface between these two depositional elements (Weimer and Slatt, 2007). Note that the master erosion surface of figure 6 extends upsection from the canyon incision surface, which cut into pre-existing Snug Harbor strata (genetically $\mathrm{Jns}_{1}$ ), into the interface between conduit fill and coeval, canyon-associated master-levee deposits (see also below). Bathymetrically defined canyon confinements in the study area were progressively buried by aggrading sediment as equilibrium profiles within the base-of-slope depositional systems were reestablished above the seafloor (for example, compare with Pirmez and others, 2000; Weimer and Slatt, 2007; Hodgson and others, 2011, 2016; also Morris and BusbySpera, 1990; Dykstra and Kneller, 2007; Sylvester and others, 2011).

\subsubsection{DEPOSITIONAL TRENDS}

Sediment gravity flow processes similar to those that cut the incipient deep-water canyons also likely rendered the lowermost canyon deposits mapped as Jns 2 (figs. 4 and 5). Jns 2 is interpreted as the record of channel belts that traversed canyon floors during an early, bypassprone, cut-and-fill episode. Coarse-grained strata (for example, amalgamated sandstones and conglomerates of figs. 4, 5, 6, and 8) were probably sourced from dense, high-energy sediment gravity flows with at least locally diminishing energy that resulted in deposition of the coarsest parts of the flows-lithologies and processes common to channel axes in deep-water settings (for example, Mutti and Normark, 1987; Williams and others, 1998; Mayall and others, 2006; Fildani and others, 2013). Fine-grained strata of $\mathrm{Jns}_{2}$ are interpreted to record deposition from lower-energy tails of chiefly bypassing sediment gravity flows (compare with Mutti and Normark, 1987; Williams and others, 1998; Posamentier and Allen, 1999; Macauley and Hubbard, 2013) and may in part be intra-canyon overbank deposits (compare with Hansen and others, 2015). Some Jns 2 sandstones are also browner-weathering than overlying gray-weathering Pomeroy Arkose strata (fig. 8), suggestive of a muddy component to the former and a cleaner aspect to the latter. The master-levee margins likely began aggrading during $\mathrm{Jns}_{2}$ time (compare with Kane and Hodgson, 2011), when mud was evidently abundant in the system and turbulent suspensions of fine-grained sediment-probably accompanying denser, coarser, canyon-floor-bound basal portions of sediment gravity flows-could overtop canyon rims (compare with Mutti and others, 1999; Peakall and others, 2000).
Locally abundant intraformational, mudstone rip-up clasts observed in $\mathrm{Jns}_{2}$ along the southwestern shore of Hickerson Lake may reflect further upslope development of the canyons via headward erosion in this early phase of canyon history. Jns ${ }_{2}$ implies a period in canyon evolution marked by erosive sediment gravity flow processes that bypassed sediment to downdip depositional reaches beyond the outcrop belt (compare with Hubbard and others, 2014; Stevenson and others, 2015).

The Jns ${ }_{2}-\mathrm{Jnp}_{1}$ contact exhibits up to several tens of meters of relief at Chisik Island (fig. 4) and the cirque localities (fig. 8). Southwest of Hickerson Lake, where $\mathrm{Jnp}_{1}$ onlaps a thick succession of $\mathrm{Jns}_{2}$, the stratigraphic relief along this contact exceeds several tens of meters, but the relations are somewhat obscured by cover (fig. 6). Regardless, the $\mathrm{Jns}_{2}-\mathrm{Jnp}_{1}$ contact is clearly associated with some degree of incision into pre-existing canyon fill, but the maximum scale at which this occurred and the balance of allogenic(?) versus autogenic influences on the stratigraphic architecture associated with this surface remain poorly constrained. Further complexity arises from the potential that at least some of the intercalated arkose and siltstone of $\mathrm{Jns}_{2}$ locally represents intra-canyon overbank strata that aggraded contemporaneously with adjacent arkosic channel fill of $\mathrm{Jnp}_{1}$ (for example, compare with Flint and others, 2011; Hodgson and others, 2011). Our observations do not require or preclude such a relation, but comparable sedimentation regimes and complexity are common to deep-water channelized depositional systems (for example, Sylvester and others, 2011).

Similar to the coarse deposits in $\mathrm{Jns}_{2}$, the locally conglomeratic, arkose-rich, Pomeroy canyon fill ( $\mathrm{Jnp}_{1}$; figs. $4,6,7 \mathrm{~B}, 9 \mathrm{C}, 10$, and 11 ) is interpreted to record dense, energetic sediment gravity flows that transported sediment along canyon-floor channel belts. $\mathrm{Jnp}_{1}$ is a chiefly mud-poor unit with few fine-grained intercalations, suggesting this stage of canyon evolution might have coincided with reduced updip incision into the Snug Harbor slope, increased sand input from coeval shelfal depositional systems, and waning growth of master levees via sedimentation from dilute, turbulent, muddy suspensions above canyon-bound, dense sediment gravity flows as noted above. However, levee growth might have continued as aggradational processes became more dominant along canyon axes during deposition of $\mathrm{Jnp}_{1}$ (see below), potentially reducing channel-belt to levee-crest relief and permitting 
coarser detritus from denser parts of sediment gravity flows to spill beyond canyon margins. Jnp ${ }_{1}$ also heralds a transition to apparently widening channel belts and increasingly gentle gradients along channel-form margins (figs. 4 and 6), as well as increasing occurrence of tabular, potentially unconfined beds (fig. 4). The degree of bypass recorded in $\mathrm{Jnp}_{1}$ is unclear, but the amalgamated, commonly channel-form arkosic beds of this unit seem to document a pronounced filling (that is to say, aggradational) phase in the canyons.

The $\mathrm{Jns}_{2}$ through $\mathrm{Jnp}_{1}$ stratigraphy is interpreted to reflect an upsection trend toward diminishing gradient along canyon axes and probable reduced bypass, although this canyon-fill evolution was seemingly punctuated by degradation along canyon thalwegs at the $\mathrm{Jns}_{2}-\mathrm{Jnp}_{1}$ contact. As discussed above, the canyonfill successions suggest a return to equilibrium profiles lying above the seafloor as base-of-slope, canyon-mouth proximal environments accumulated sediment, and sand-choked depositional systems of the Pomeroy (including $\mathrm{Jnp}_{1}$ and chiefly $\mathrm{Jnp}_{2}$ ) backstepped and onlapped the inherited and locally modified bathymetric expression of the Snug Harbor slope. The sand-rich, mud-poor nature of $\mathrm{Jnp}_{1}$ may have reduced efficiency of the unit's sediment gravity flows (for example, compare with Mutti and Normark, 1987), potentially diminishing runout of the sandy flows at the slope-basin floor transition and rendering thick accumulations of channelized arkosic deposits approaching canyon mouths. Finally, the sandy, amalgamated, tabular-bodied deposits of Jnp 2 (fig. 4) are interpreted to record distributary lobe sedimentation in basin-floor fans beyond canyon mouths that were likely tied to the base-of-slope gradient break and retreated farther upslope as arkosic sediment continued to spill onto the basin floor (fig. 14; compare

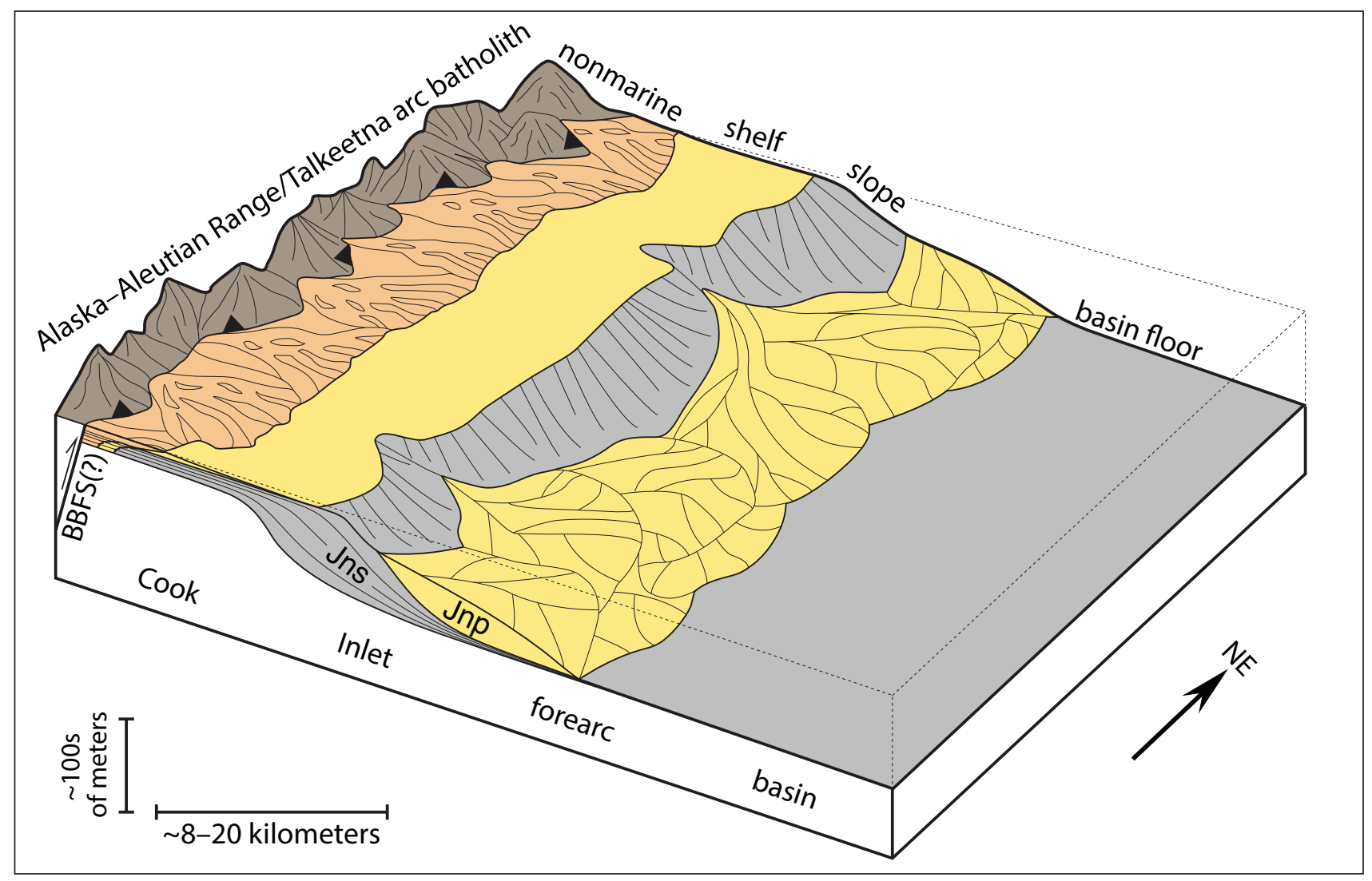

Figure 14. Generalized block diagram exhibiting stratigraphic and structural relations of the basin margin associated with the Naknek Formation deep-water canyons. The inferred marginal marine and shelfal record was eroded during later deformation of the forearc basin stratigraphy. This model depicts major stratigraphic elements of HST, but portrays mid to late LST-2 time (see section 3); pre-HST stratigraphy is not shown, nor are sub-member-scale Snug Harbor Siltstone (Jns) and Pomeroy Arkose (Jnp) units; master-levee deposits are also omitted, but would lie along margins of lower canyon reaches and extend onto the proximal parts of onlapping basin-floor fan complexes. The Naknek canyons and associated stratigraphic elements documented in outcrop are interpreted to expose depositional settings at and near the base of slope. Figure adapted from Reading and Richards (1994), Richards and others (1998), and Weimer and Slatt (2007). Abbreviations: BBFS(?) = Bruin Bay fault system(?) (query indicates uncertainty in fault system's influence on Naknek sedimentation [see text for discussion]; northwest dip magnitude not drawn to scale); NE = northeast. 
with Mutti and Normark, 1987; Galloway, 1998; Wynn and others, 2002; Stevenson and others, 2015; Hodgson and others, 2016).

\subsubsection{CANYON ORIENTATION, MORPHOLOGY, AND SPACING}

The Naknek canyons' axes are only generally constrained by their mountain-scale exposures documented above, although the canyons do not appear to be oriented at highly oblique angles to the overall outcrop trends. The laterally extensive Naknek facies belts of the study area suggest a northeastward depositional strike consistent with the basin margin orientation and location of nearby Talkeetna arc rocks (see section 1.2). These constraints and, more specifically, the along-strike consistency of Pomeroy Arkose strata of base-of-slope and basinfloor affinity stacked on Snug Harbor Siltstone strata of slope affinity throughout the Iniskin-Tuxedni bays study area indicates that the Snug Harbor slope faced southeast. We thus propose that the paleocanyons trended approximately southeastward, parallel to the inferred maximum gradient of the slope's profile and approximately orthogonal to the basin margin (fig. 14), although deviation of canyon axes from regional slope dip may occur where pre-existing seafloor bathymetric lows or structural controls exist (for example, Dykstra and Kneller, 2007; Kane and others, 2009).

The canyon-bounding surfaces of this study are undoubtedly compound and time transgressive. That is to say, the slope incision processes that yielded the incipient Naknek canyons occurred during a somewhat prolonged period driven by the passage of countless sediment gravity flows (compare with Sylvester and others, 2011; Bain and Hubbard, 2016; Hodgson and others, 2016). Additionally, master levee confinement is never instantaneous, as levee growth is accomplished by incremental accumulation of sediment in thin-bedded, dominantly fine-grained deposits. In addition, channel margins at all scales are subjected to modification via erosional processes inherent to channelized depositional systems. Therefore, the stratigraphic surface that lies along a canyon fill-to-host facies interface does not represent a paleobathymetric surface, but rather a composited surface that never existed in its entirety along the seafloor at any one time. Hodgson and others (2016) presented a model that addresses the diachronous nature of master bounding surfaces in deep-water, channelized depositional settings. A similar notion has been described for shelfal valley forms as well, with a clear distinction between stratigraphic valleys versus paleotopographic/paleobathymetric valleys (Strong and Paola, 2008); in this sense, we employ the term stratigraphic canyon in the following paragraph. Nevertheless, although the size of the Naknek canyons on the paleoseafloor could not have exceeded their scale in the stratigraphic record (constraints discussed below), the paleobathymetric expressions of the canyons may have, in general, resembled the morphologic character reflected in figures 4 and 6-10 (compare with Sylvester and others, 2011; Hodgson and others, 2016; also Strong and Paola, 2008).

Mapping the lateral distribution of canyon fills, margin elements, and bounding surfaces provides minimum scale constraints for the stratigraphic canyon widths. Although canyon rims-probably defined by masterlevee crests-were not definitively observed during this study, the thickened Snug Harbor successions near peak 3140 and Mount Pomeroy (figs. 6 and 10) suggest that beyond-crest thinning of master-levee wedges occurs southwest and northeast (or east) of those localities, respectively. A relatively thin Snug Harbor succession lies northeast of Hickerson Lake (fig. 7A), indicating the canyon-bounding surface of figure 8 (orange longdashed line) is continuous with the equivalent surface in figure 6 and is at or below the base of Pomeroy in figure 7. Therefore, the minimum stratigraphic width of the Hickerson Lake area canyon is approximately $6 \mathrm{~km}$ (the distance between the northeast cirque locality and peak 3410 [fig. 3A]). Our geologic mapping indicates that the Mount Pomeroy area canyon extends along strike into Iniskin Bay, establishing a minimum stratigraphic width of approximately $4 \mathrm{~km}$ (the distance between Mount Pomeroy and Iniskin Bay [fig. 3B]; also fig. 10). The Chisik Island canyon exposure constrains a minimum stratigraphic width of approximately $1 \mathrm{~km}$ (fig. 4). Thicknesses of compacted canyon-fill successions establish minimum stratigraphic canyon depths of approximately $190 \mathrm{~m}, 400 \mathrm{~m}$, and $175 \mathrm{~m}$ at the Chisik Island (fig. 4; Jns $_{2}$ plus Jnp ${ }_{1}$ ), Hickerson Lake (fig. 6; Jns ${ }_{2}$ plus $\mathrm{Jnp}_{1}$ ), and Mount Pomeroy (fig. 10; $\mathrm{Jnp}_{1}$ ) areas, respectively. The Hickerson Lake area canyon constitutes the largest-scale (albeit a minimum) stratigraphic canyon in the study area at approximately $6 \mathrm{~km}$ wide by $400 \mathrm{~m}$ deep, but all the canyons have stratigraphic expressions on the order of kilometers wide by hundreds of meters deep. Figure 15 presents a schematic 


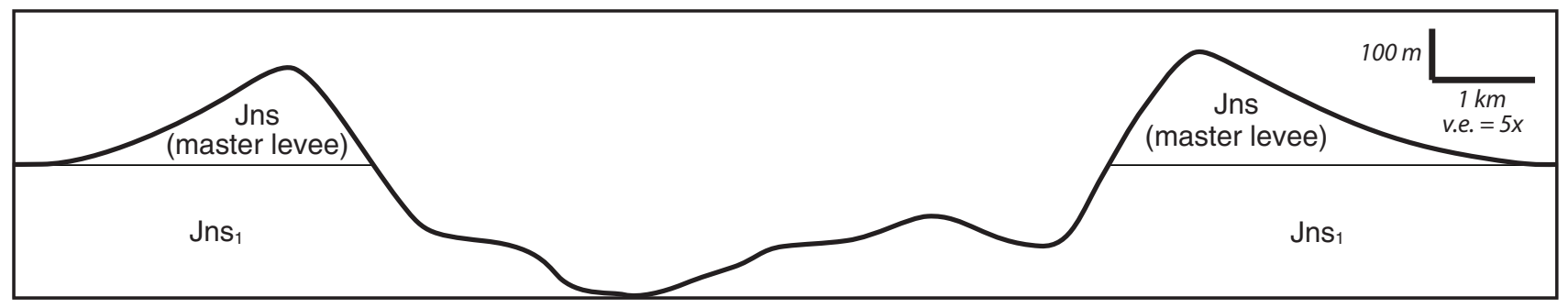

Figure 15. Schematic, down-dip view of a generalized Naknek Formation deep-water canyon. This interpretation integrates observations from Chisik Island and the Hickerson Lake and Mount Pomeroy areas. Canyon-bounding elements comprise incised, lithostratigraphically typical Snug Harbor Siltstone Member ( $\mathrm{Jns}_{1}$ ) and aggraded master levees. The thick black line between master-levee crests is equivalent to the orange long-dashed lines of figures 4, 5, 6, and 8; see text for discussion of the composited, time-transgressive nature of this stratigraphic canyon-bounding surface. Canyon-fill strata (Jns 2 and Pomeroy Arkose Member) are omitted. Abbreviations: Jns = Snug Harbor Siltstone Member, Naknek Formation; v.e. = vertical exaggeration.

stratigraphic canyon profile that is consistent with the constraints reported above.

The Chisik Island, Hickerson Lake, and Mount Pomeroy area observations establish a maximum canyon spacing of approximately $30-40 \mathrm{~km}$ along the Late Jurassic basin margin (fig. 1). Although additional canyons may yet be recognized in the outcrop belt of the study area, this maximum canyon spacing suggests that basin-floor fans comprising coalesced distributary lobes potentially radiated for $15 \mathrm{~km}$ or more beyond their canyon sources as base-of-slope and proximal basin-floor environments accumulated sediment (fig. 14). Whether additional Pomeroy Arkose sediment spilled across the shelf edge in inter-canyon areas and was shunted to the basin floor via non-canyon confined flows is not currently constrained. The implications of these deep-water canyons for understanding sediment supply regimes to deep-water Snug Harbor and Pomeroy depositional systems and identifying base-level cycles in the Naknek Formation are discussed in the next section.

\section{SEQUENCE STRATIGRAPHY OF THE NAKNEK FORMATION}

Sequence stratigraphy (Posamentier and others, 1988; Posamentier and Vail, 1988; Van Wagoner and others, 1988) has, during the past several decades, developed into a widely employed method of stratigraphic analysis, stemming in large part from the pioneering work by petroleum geologists in their examination of basin-fill architectures interpreted from seismic reflection data (Payton, 1977; Vail and others, 1977). Applications of this method are yielding important advances in stratigraphic studies (see discussions by Miall and Miall, 2001; Catuneanu, 2002), providing a useful tool to better understand sedimentary processes in both nonmarine and marine settings (see reviews by Catuneanu and others, 2009, 2011). Sequence-stratigraphic work ideally integrates numerous datasets and recognizes that the interplay between accommodation ${ }^{5}$ and sediment supply yields cyclic patterns of sedimentation as the balance alternates between these two fundamental factors (for example, Neal and Abreu, 2009). Identification of sequence-stratigraphic surfaces, and thus pivotal changes in the base-level ${ }^{6} \mathrm{cycle}$, is integral to the method, but these surfaces may be enigmatic or poorly developed in deep-marine environments compared to the commonly higher fidelity record of shallowmarine settings (Catuneanu and others, 2009; Neal and Abreu, 2009). Fortunately, excellent outcrops in the Iniskin-Tuxedni bays study area permit identification of key surfaces throughout the Naknek Formation's shallow- and deep-water stratigraphy, including the canyon-associated successions. The following sequencestratigraphic analysis incorporates our outcrop-based observations and interpretations of facies relations and stratigraphic architecture, rendering insights into the evolution of Naknek Formation depositional systems and highlighting the relevance of this work to Cook Inlet petroleum systems. This investigation also sheds light on the tectonic, eustatic, and climatic signals recorded within the Late Jurassic Cook Inlet forearc basin; a brief introduction to some of these implications is included below.

${ }^{5}$ Defined by Jervey (1988) as "the space made available for potential sediment accumulation."

${ }^{6} \mathrm{~A}$ conceptual, dynamic surface that delineates where the balance between erosion and deposition lies in active depositional systems (for example, Catuneanu and others, 2009). Accommodation space always lies below this surface, which in marine environments is commonly approximated as sea level (Jervey, 1988). 


\subsection{Methods and Terminology}

This sequence-stratigraphic interpretation of the Naknek Formation is supported by sedimentologic and stratigraphic work of Wartes and others (2011, 2013, 2015), Herriott and Wartes (2014), and Herriott and others (2015a, 2015b, 2015c, 2016a), section 2 of this paper, and many of our previously unpublished observations and interpretations (see also LePain and others, 2013). Facies association stacking trends and stratal terminations are employed to identify sequence-stratigraphic surfaces that envelop systems tracts, reflecting changes in accommodation and sediment supply and permitting interpretation of base-level cycles. This study follows the conceptual framework of Posamentier and Allen (1999) in the placement of three sequencestratigraphic surfaces and naming of three systems tracts in a stratigraphic sequence (fig. 16). These surfaces and systems tracts are mapped onto the oblique-view photogeologic figures presented below. Terms that we employ in this analysis are discussed in the following paragraph and set in underlined italics, with additional

\begin{tabular}{|c|}
\hline Basal Surface of Forced \\
\hline Regression (BSFR) \\
HIGHSTAND SYSTEMS \\
TRACT (HST) \\
Maximum Flooding \\
Surface (MFS) \\
TRANSGRESSIVE \\
SYSTEMS TRACT (TST) \\
Transgressive \\
Surface (TS) \\
LOWSTAND SYSTEMS \\
TRACT (LST) \\
Basal Surface of Forced \\
\hline Regresssion (BSFR)
\end{tabular}

Figure 16. Schematic framework of sequence-stratigraphic surfaces and systems tracts employed by this study. The basal surface of forced regression serves as the sequence boundary, with a stratigraphic sequence comprising the intervening stratigraphy. See text for further discussion of this terminology and its application to the Naknek Formation. sequence-stratigraphic terms introduced for context and/or comparison set in italics. It is imperative to clearly define these sequence-stratigraphic surfaces and systems tracts, because the relevance of this paper must remain independent of the specific approach that is utilized (see discussion by Catuneanu and others, 2009).

Naknek Formation sequence boundaries delineated by this study are consistent with placement of correlative conformities in the sense of Posamentier and Allen (1999; compare to Hunt and Tucker, 1992), but we refer to them as basal surfaces of forced regression (Hunt and Tucker, 1992) because they mark onset of baselevel fall and are at least locally erosional. Our usage of lowstand systems tract (in the sense of Posamentier and Allen, 1999) includes the falling stage systems tract (Plint and Nummedal, 2000) that comprises forced regressive deposits (Plint, 1991; Posamentier and others, 1992; Posamentier and Morris, 2000) and the lowstand systems tract (in the sense of the review by Catuneanu and others, 2011) that comprises lowstand normal regressive deposits (Posamentier and others, 1992; see also Catuneanu, 2002, 2006). Usage of transgressive surface, transgressive systems tract, and maximum flooding surface are straightforward in the literature and their application here; refer to Catuneanu and others (2009, 2011) for definitions and synonymous terms. We recognize highstand systems tract in the sense of Posamentier and Allen (1999), which includes all highstand normal regressive deposits (Catuneanu, 2002, 2006; Catuneanu and others, 2011).

\subsection{Naknek Formation Surfaces, Systems Tracts, and Stratigraphic Sequences}

The base of the Naknek Formation is locally erosional where the boulder-bearing Chisik Conglomerate Member of fan delta affinity (Wartes and others, 2011, 2013) overlies the shelfal Paveloff Siltstone Member of the Chinitna Formation (fig. 17) (LePain and others, 2013; Herriott and Wartes, 2014; Wartes and Herriott, 2015; Herriott and others, 2016b). Elsewhere, the Chinitna-Naknek contact is less prominent and probably represents a depositional hiatus of less than 1 million years at the end of the Callovian (Detterman and Hartsock, 1966; Imlay, 1975). This locally erosional hiatus is interpreted as a basal surface of forced regression and base-of-Naknek sequence boundary (BSFR/SB-1) that is overlain by a lowstand systems tract (LST-1) comprising the Chisik and lower sandstone (figs. 17 and 18). 

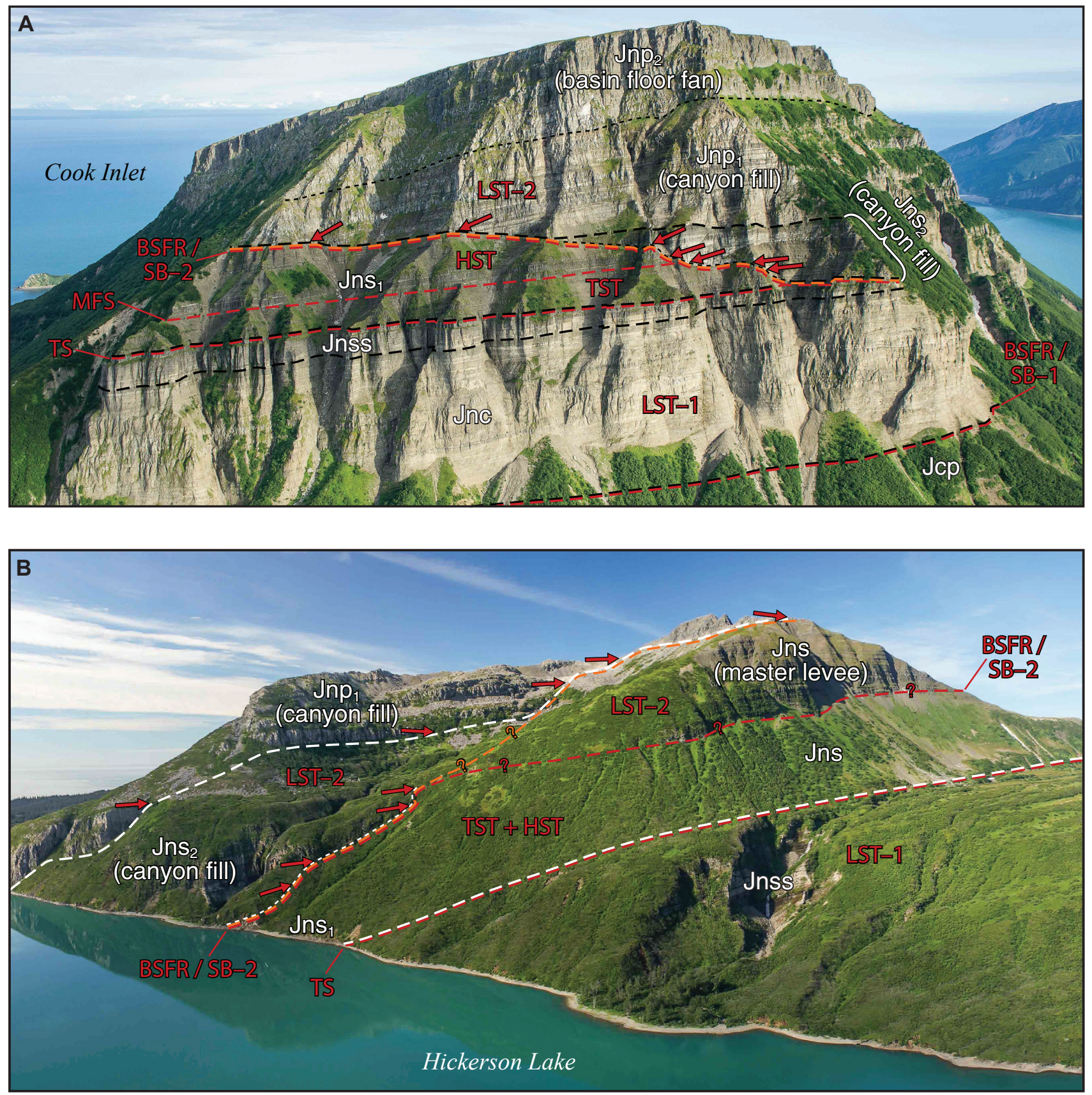

Figure 17. Oblique aerial photographs depicting mountain-scale outcrop expression of sequence-stratigraphic (red dashed lines and red labels) and lithostratigraphic (black or white dashed lines and white labels) units and surfaces in the Naknek Formation of canyonassociated areas; parenthetical labels are interpretations supported by lithostratigraphic and sequence-stratigraphic lines of evidence. (A) View southeastward of the Chisik Island canyon locality. See text for discussion of stratigraphic relations. The exposure is $900 \mathrm{~m}$ wide at brush line near the Naknek-Chinitna Formations contact, for sense of scale. See figure 4A for noninterpreted photograph and additional context. (B) View southwestward of the Hickerson Lake area canyon near peak 3140. Note that the master-levee succession-a canyon-associated element of LST-2-is partly enveloped by the diverging canyon margin (orange long-dashed line; master erosion surface of figs. 4, 6, 8, and 17A) and BSFR/SB-2. The intra-Jns maximum flooding surface is not identified here due to poor exposure (compare to $A$; compare with D). Snug Harbor is $\sim 500 \mathrm{~m}$ thick at right of figure, for sense of scale. See figure $6 \mathrm{~A}$ for noninterpreted photograph and additional context. 

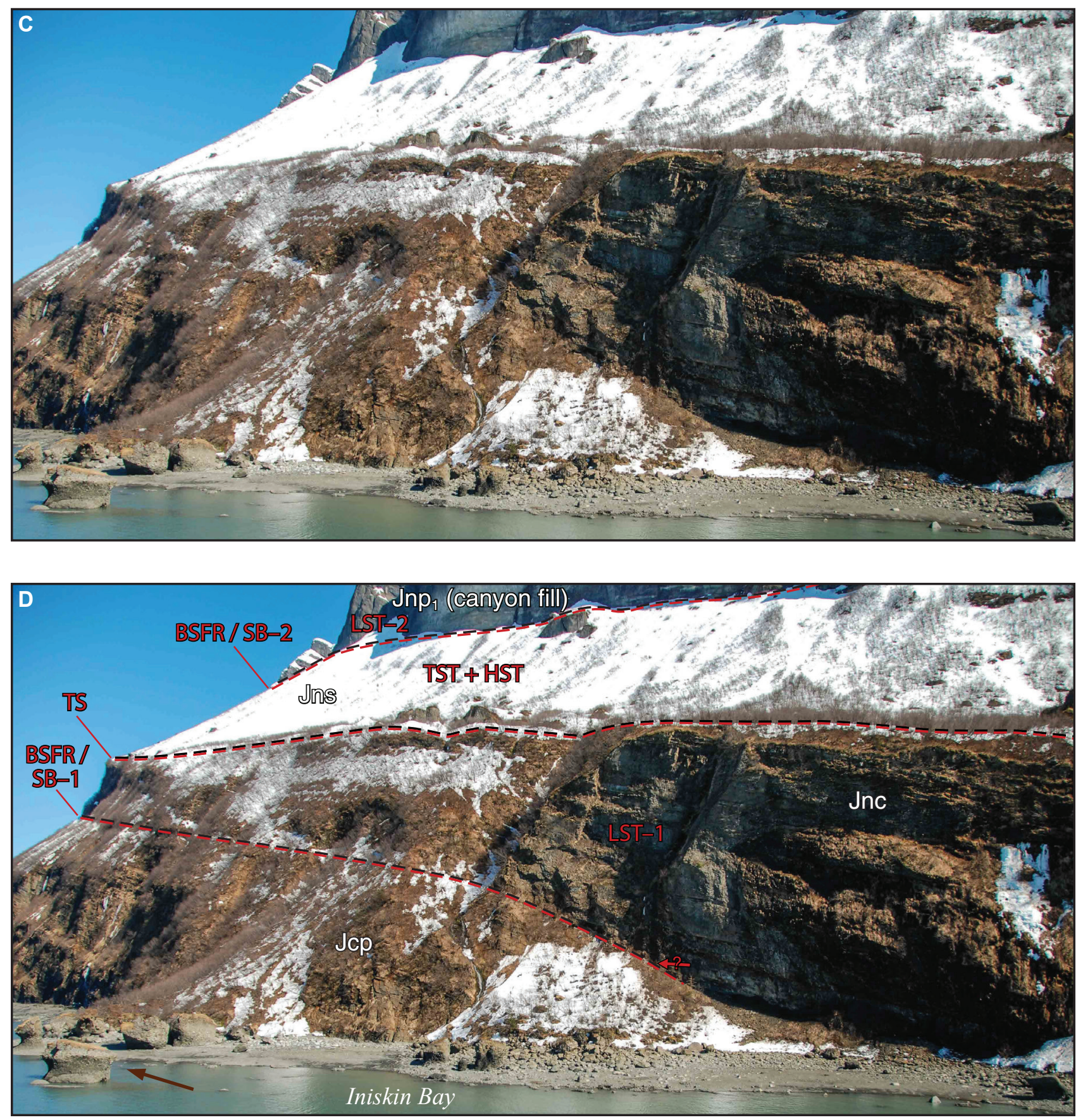

Figure 17, continued. (C) View eastward of The Toadstools (identified by brown arrow in D) area of Iniskin Bay. (D) Sequence-stratigraphic interpretation (with lithostratigraphic units) of C. The amount of apparent onlap of Chisik onto the Paveloff Siltstone Member (Jcp; see small red queried arrow) may be exaggerated due to talus cover, but some degree of onlap across the sequence boundary (BSFR/SB-1) is consistent with stacking of fan delta deposits on shelf strata (compare with Posamentier and Allen, 1999). Similar to B, the intra-Jns maximum flooding surface is not identified due to poor exposure. View is nearly strike parallel. Chisik is $131 \mathrm{~m}$ thick at deeply shadowed gorge (right of LST-1 label), for sense of scale. See figure 10A and B for a higher-altitude perspective of this area. Lithostratigraphic linework of D modified after Herriott and Wartes (2014). Additional line symbology after figures 4 and 6. Small red arrows mark onlapping stratal terminations. Stratigraphic units (ascending order): Jcp = Paveloff Siltstone Member, Chinitna Formation; Jnc = Chisik Conglomerate Member, Naknek Formation; Inss = lower sandstone member, Naknek Formation; Ins = Snug Harbor Siltstone Member, Naknek Formation; Jnp = Pomeroy Arkose Member, Naknek Formation. Sequence-stratigraphic surfaces and units (ascending order): BSFR/SB-1 = basal surface of forced regression/sequence boundary 1; LST-1 = lowstand systems tract $1 ;$ TS = transgressive surface; TST + HST = transgressive systems tract and highstand systems tract; BSFR/SB-2 = basal surface of forced regression/sequence boundary 2; LST-2 = lowstand systems tract 2. Photographs by T.M. Herriott. 

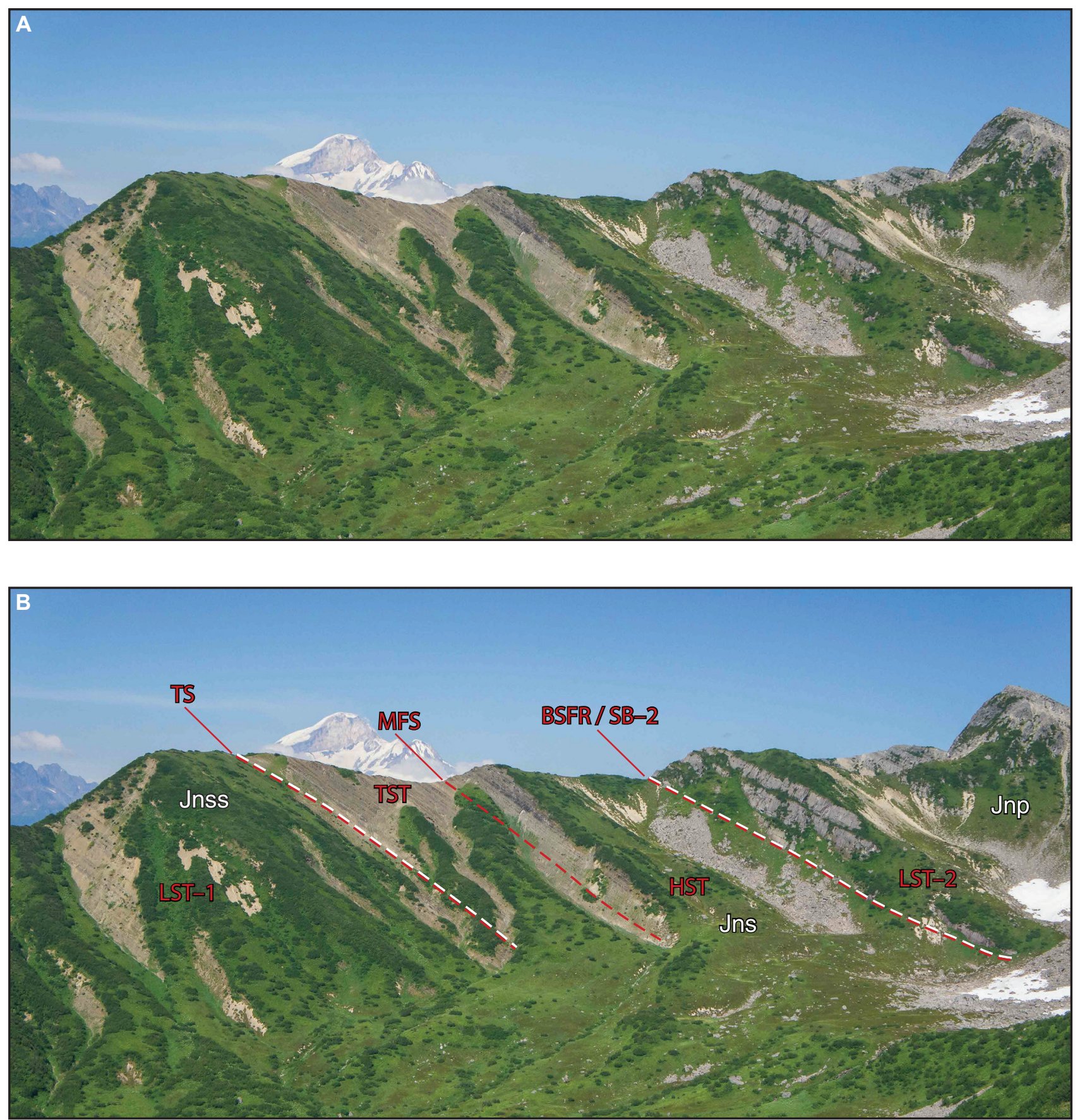

Figure 18. Oblique aerial photographs depicting mountain-scale outcrop expression of sequence-stratigraphic (red dashed lines and red labels) and lithostratigraphic (white dashed lines and white labels) units and surfaces in the Naknek Formation of inter-canyon areas. (A) View northeastward of a ridge southeast of Griffin Creek (fig. 1). (B) Sequence-stratigraphic interpretation (with lithostratigraphic units) of A. BSFR/SB-2 is conformable in inter-canyon areas (see also D). View is approximately strike parallel. Jns extends for $\sim 430 \mathrm{~m}$ along the ridge, for sense of scale. 

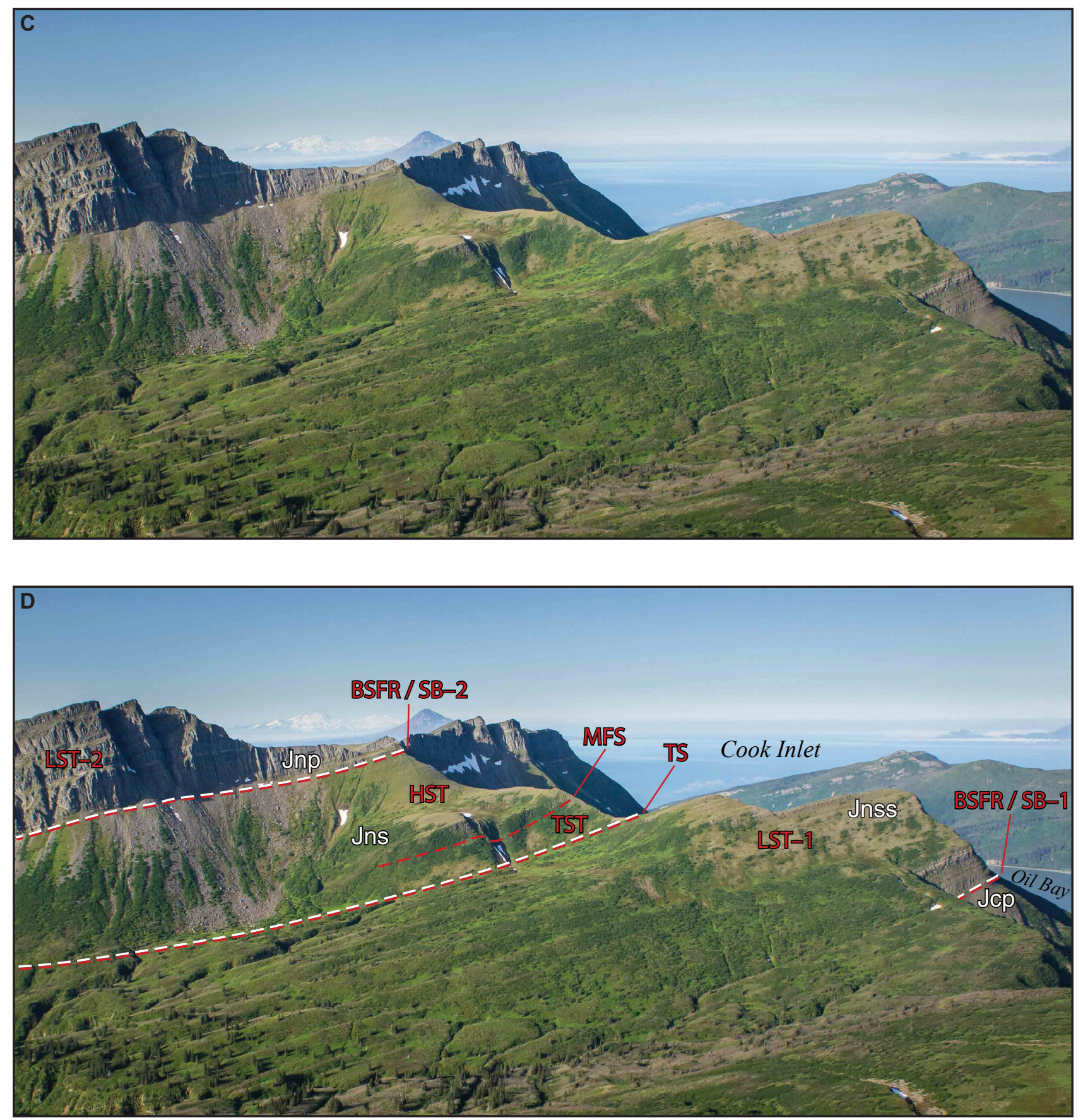

Figure 18, continued. (C) View southwestward of the Shark Tooth Hill area (fig. 1). (D) Sequence-stratigraphic interpretation (with lithostratigraphic units) of C. View is approximately strike parallel. The Snug Harbor is $285 \mathrm{~m}$ thick, for sense of scale. Lithostratigraphic linework for B and D from Herriott and Wartes (2014). Stratigraphic units (ascending order): Jcp = Paveloff Siltstone Member, Chinitna Formation; Jnss = lower sandstone member, Naknek Formation; Ins = Snug Harbor Siltstone Member, Naknek Formation; Jnp = Pomeroy Arkose Member, Naknek Formation. Sequence-stratigraphic surfaces and units (ascending order): BSFR/SB-1 = basal surface of forced regression/sequence boundary 1; LST-1 = lowstand systems tract 1; TS = transgressive surface; TST = transgressive systems tract; $\mathrm{MFS}=$ maximum flooding surface; HST = highstand systems tract; BSFR/SB-2 = basal surface of forced regression/sequence boundary 2; LST-2 $=$ lowstand systems tract 2 . Photographs by T.M. Herriott. 
Outcrop evidence of subaerial exposure along BSFR/ SB-1 is enigmatic or lacking. The top of LST-1 occurs where the Snug Harbor Siltstone Member sharply overlies these basal Naknek members, marking a transgressive surface at the onset of a transgressive systems tract (TST) in lower Snug Harbor (outer shelf deposits: this study; see also Wartes and others, 2013) (figs. 17 and 18). A series of very thin pebble- and granulebearing horizons with fossil hash are locally observed in an approximately 25 -cm-thick interval along the lower sandstone-Snug Harbor contact and interpreted as transgressive lag deposits.

Examination of the Snug Harbor weathering profile and field observations described by Herriott and Wartes (2014) suggest a candidate maximum flooding surface lies at the base of a mid Snug Harbor resistant interval (slope deposits: this study; see also Wartes and others, 2013), capping TST (fig. 18). The weathering resistance of this laterally persistent interval reflects a somewhat coarser-grained and thicker-bedded Snug Harbor package that is consistent with a highstand systems tract (HST) (fig. 18) (compare with Posamentier and Allen, 1999) and contrasts with the underlying recessive, thinner-bedded and finer-grained basal section of the member (TST discussed above).

We interpret the slope-incised canyon floors and margins to form part of a deep-water basal surface of forced regression (BSFR/SB-2), a sequence boundary that marks cessation of HST (fig. 17) (compare with Mayall and others, 2006; Di Celma, 2011; Williams and Graham, 2013). Canyon-associated Snug Harbor strata are locally observed and constitute both canyon-fill $\left(\mathrm{Jns}_{2}\right)$ and master levees that overlie BSFR/SB-2 (fig. 17A and $\mathrm{B}$ ). In inter-canyon areas, where the stratigraphy is conformable and a master-levee succession is absent, we propose the Snug Harbor-Pomeroy contact is coincident with BSFR/SB-2, with base-of-slope to basin-floor Pomeroy of a lowstand systems tract (LST-2) stacked on slope strata of the Snug Harbor (HST) (figs. 14 and 18) (Wartes and others, 2013; also LePain and others, 2013). The top of LST-2 is not identified by this study, although our reconnaissance of the nearly $1-\mathrm{km}$-thick Pomeroy suggests the member contains additional sequence-stratigraphic surfaces and systems tracts. Regardless, LST-2 comprises all canyon associateddeposits, including $\mathrm{Jns}_{2}$ and the master levees, and at least the lower several hundred meters of the Pomeroy, constituting the cliff-forming, amalgamated arkosic strata of figures 4, 6-10, 17, and 18 .

This proposed framework indicates that a complete stratigraphic sequence occurs in LST-1, TST, and HST recorded by the Chisik, lower sandstone, and precanyon Snug Harbor, with the latter locally mapped as $\mathrm{Jns}_{1}$ near the canyon localities and as undifferentiated Jns in inter-canyon areas; note that $\mathrm{Jns}_{1}$ includes both TST and HST. Onset of a renewed cycle of sedimentation in an overlying stratigraphic sequence is marked by LST-2, which comprises canyon-associated Snug Harbor strata (Jns 2 and master-levee deposits) and Pomeroy $\left(\mathrm{Jnp}_{1}, \mathrm{Jnp}_{2}\right.$, and undifferentiated Jnp) (figs. 17 and 18). The LST-1 through HST stratigraphic sequence may span approximately 6 million years, as suggested by the biostratigraphic age constraints for the Naknek in the study area (Imlay, 1981) and the approximate duration of the Oxfordian (Cohen and others, 2013). This stratigraphic sequence thus reflects a third-order (that is to say, $10^{6}$ years duration [see discussion by Miall, 2010]) base-level cycle.

\subsection{Naknek Formation Base-Level Cycles, Shoreline Trends, and Depositional Systems}

Base level fell prior to the onset of Naknek deposition, yielding a period of limited to negative shore-zone accommodation (for example, compare with Catuneanu and others, 2009) as the paleoshoreline was forced basinward, terminating deposition of the Chinitna Formation and establishing BSFR/SB-1. Syndepositional activity on the nearby Bruin Bay fault system (fig. 2) (Detterman and Hartsock, 1966; Detterman and Reed, 1980; Wartes and others, 2011, 2013; LePain and others, 2013; see also Trop and others, 2005) may have in part driven the strong sediment supply signal of LST-1 by steepening hanging wall (arcward) fluvial gradients, resulting in widespread bypass-prone conditions in nonmarine environments. Wartes and others (2015) reported angular unconformities in the lower sandstone member that subtly cut downsection toward the basin margin and suggested these surfaces may reflect uplift in the arc. LST-1 also notably marks commencement of abundant supply of arkosic sediment, which was derived from the Talkeetna arc's plutonic roots in the Alaska-Aleutian Range batholith (figs. 1 and 2). The arkosic character of LST-1 contrasts with the volcanic lithic-rich character of the Middle Jurassic forearc 
stratigraphy (for example, Helmold and others, 2013). These structural-stratigraphic relations are consistent with work by Trop and others (2005), who documented syntectonic inception of Naknek Formation deposition during early Oxfordian in the Talkeetna Mountains approximately $400 \mathrm{~km}$ northeast of the Iniskin-Tuxedni bays area (fig. 1). These long-distance correlations also are consistent with structural-stratigraphic relations reported on the Alaska Peninsula that similarly indicate exhumation of the adjacent magmatic arc contemporaneous to onset of Naknek deposition (Detterman and others, 1996). Collectively, these regionally extensive trends suggest that plate-scale convergent margin tectonics influenced the stratigraphic evolution of the arc-forearc region during LST-1.

Distinguishing forced regressive strata from lowstand normal regressive strata is commonly challenging (Plint and Nummedal, 2000), although our preliminary work on making such a distinction indicates that this forced regression to lowstand normal regression transition-a correlative conformity in the sense of Hunt and Tucker (1992) — may be at least locally identifiable (Herriott and others, 2015c; see also terminology section above; compare with Catuneanu and others, 2011). Within the scope of this paper, we simply highlight that this transition lies within LST-1 and heralded onset of base-level rise that continued through the remainder of the LST-1-TST-HST sequence. Maximum shoreline regression marked the end of LST-1, yielding onset of Snug Harbor deposition in TST. The ensuing transgression stacked outer-shelf Snug Harbor strata on top of inner-shelf lower sandstone (fig. 18) and, locally, fan delta deposits of the Chisik (fig. 17), indicating accommodation creation outpaced sediment supply as base level continued to rise. At a minimum the landwardstepping shoreline of TST neared the leading edge of the Bruin Bay fault system, which typically lies within 10-20 $\mathrm{km}$ of the Snug Harbor outcrop trend (Detterman and Hartsock, 1966), although the basin margin stratigraphy was later shortened by tectonic deformation. However, TST deposits of the Snug Harbor crop out within several kilometers of the Bruin Bay fault system in the Iniskin Bay area, and geologic mapping by Wartes and others (2016) indicates that this transgression probably flooded across (that is to say, to an arcward position of) the mapped trace of the fault system where Snug Harbor strata occur in its immediate footwall north of Chinitna Bay. Therefore, if the Bruin Bay fault system was active during Naknek sedimentation, these relations suggest fault slip may have transferred to a more hindward structure in the fault system or that fault slip at the basin margin decreased or halted during this transgression, leading to a period of reduced sediment supply and marine inundation toward the structural front of the magmatic arc. As noted above, stratigraphic studies suggest Oxfordian slip along the Bruin Bay fault system (Detterman and Hartsock, 1966; Detterman and Reed, 1980; Wartes and others, 2011, 2013; LePain and others, 2013; also Trop and others, 2005), and ongoing kinematic studies aim to delineate the timing and nature of deformation along the fault system (Gillis and others, 2013a; Betka and Gillis 2014a, 2014b, 2015, 2016). However, the degree, if any, to which the Bruin Bay fault system influenced forearc basin sediment supply and subsidence remains an outstanding question, and lithosphere-scale exhumation and subsidence processes must be considered as well (see below).

The most landward position of the TST shoreline was achieved during establishment of the intra-Snug Harbor maximum flooding surface. Above this surface, sediment supply outpaced accommodation creation during continued base-level rise, with aggradation and an increasing component of progradation occurring during highstand normal regression of HST. Note that regression accompanying highstand systems tracts need not be driven by significant changes in base-level rise, but the transgression to highstand normal regression shoreline trajectory reversal simply indicates a shift from accommodation-favored to sediment-supplyfavored conditions. Nevertheless, we hypothesize that the transition from TST to HST across the maximum flooding surface is pivotal in the stratigraphic evolution of the Naknek, marking a shift from outer shelf to slope sedimentation in the study area as inferred Snug Harbor clinoforms (HST) prograded across the TST deposits that draped the relict, inherited lower sandstone shelf.

Marked base-level fall and forced regression is recorded by BSFR/SB-2, terminating HST, locally forcing equilibrium profiles below the slope's seafloor via increased environmental energy flux, and leading to erosional inception of the deep-water canyons described in this paper. Accommodation in the downstream nonmarine and shallow-marine environments was likely negative and low, respectively, at onset of LST-2 (compare with Catuneanu and others, 2009; Catuneanu and Zecchin, 2016), promoting bypass and exporting sediment off 
the shelf and into the canyons; most of this sediment load during an early, forced regressive phase of LST-2 probably bypassed the slope as well, with canyon-hosted sediment gravity flows primarily depositing their loads near and beyond base-of-slope settings and recorded in part by $\mathrm{Jns}_{2}$. Dilute clouds of suspended sediment accompanying the denser, canyon-bound portions of these sediment gravity flows likely promoted aggradational growth of canyon-bounding master levees during deposition of LST-2 (compare with Hodgson and others, 2016). Although the LST-2 paleoshoreline was forced basinward along and above BSFR/SB-2, no contemporaneous shallow-marine deposits crop out in the study area, where deposition remained deep marine across this surface. A fundamental characteristic of this regressive episode is that coarse and abundant sediment was routed to deep-water reaches following establishment of the canyons-associated sequence boundary (BSFR/SB-2), ultimately rendering the thick, commonly amalgamated, mud-poor, gravel-bearing, and sand-rich lower Pomeroy of the canyon fills ( $\left.\mathrm{Jnp}_{1}\right)$ and overlying successions ( $\mathrm{Jnp}_{2}$ and undifferentiated Jnp). Additionally, although allogenically driven slope incision defined canyon inception and possibly triggered degradation during early filling phases of canyon evolution (see above; also $\mathrm{Jns}_{2}-\mathrm{Jnp}_{1}$ contact of fig. 6), deep-water accommodation at the base of the Snug Harbor slope was probably plentiful following the systems' ultimate return of equilibrium profiles to above the seafloor. We interpret that formation of the canyons and export of $\mathrm{Jns}_{2}$ and Pomeroy sediments to deep-water settings was likely triggered by additional exhumation of the magmatic arc that, once again, may have been accomplished in part by slip along the Bruin Bay fault system. LST-2 hosts an as-yet-to-be-defined deep-water correlative conformity (in the sense of Hunt and Tucker, 1992); future work on the Pomeroy Arkose Member may identify a candidate for this surface that separates forced regressive deposits from overlying lowstand normal regressive deposits in LST-2.

Figure 14 presents a depositional model portraying stratigraphic elements of HST and LST-2. The Chisik Island, Hickerson Lake, and Mount Pomeroy canyons and the deep-water aspects of the sequence-stratigraphic interpretation yield several insights relevant to basin evolution and physiography during Snug Harbor and Pomeroy time:
1. Stacking of a highstand systems tract on a transgressive systems tract predicts progradation of clinoforms in the upper Snug Harbor HST (compare with Neal and Abreu, 2009), although such a prediction should not be considered to be conclusive. However, establishment of a shelfslope-basin-floor depositional profile by HST clinoforms is consistent with subsequent canyon development, as increased seafloor gradient drives deep-water erosion, which is a gravity-driven process common to slopes (Galloway and Hobday, 1996; Galloway, 1998).

2. Further evidence of a shelf-slope-basin-floor profile is provided by stacking of Pomeroy Arkose of base-of-slope and basin-floor affinity (LST-2) on Snug Harbor Siltstone of slope affinity (HST) in inter-canyon areas (fig. 18) (LePain and others, 2013; Wartes and others, 2013; Herriott and Wartes, 2014). Pomeroy deposition occurred at and beyond the slope-basin-floor gradient transition (for example, compare with Pickering and others, 1989; Galloway and Hobday, 1996; Galloway, 1998; discussion above), a setting characterized by diminishing sediment gravity flow energyvia deceleration-where sand-rich, deep-water successions are deposited in modern deep-water environments and documented in the rock record (see review by Weimer and Slatt, 2007). In contrast, basins lacking shelf-slope-basin-floor gradient breaks and exhibiting low-gradient, ramp-like depositional profiles (for example, tectonically sluggish interior seaways) do not host thick, deepwater sandstone successions (Posamentier and Allen, 1999).

3. Sandstones of the Pomeroy Arkose Member may have a somewhat limited depositional distribution downdip of the Iniskin-Tuxedni bays region. In other words, as a sand-rich, base-of-slope and basin-floor unit, the Pomeroy may be wedgeshaped in depositional profile, likely thinning markedly basinward by downlap of a basin-floor fan complex. This is reflected in our interpretive model of figure 14; additional considerations regarding the potential distal extents of the Pomeroy are presented below. 
4. We hypothesize that a potentially narrow $(<10$ $\mathrm{km}[?])$, sandy shelf and coastal plain constituted the shallow- to marginal-marine part of LST-2, with location constraints provided by the deepwater depositional elements of the outcrop belt and, at least tentatively, modern exposures of the magmatic arc and Bruin Bay fault system (figs. 1-3 and 14). Furthermore, LST-2 depositional systems were capable of supplying and transporting from subaerial source to deep-water sink the caliber and volume of sediment observed in outcrop (figs. 4-11, 17, and 18). Relatively steep, narrow shelves are well suited to meet this requirement as they can bypass coarse, well-winnowed sediment to canyon-associated deep-water settings (Sweet and Blum, 2016); narrow shelves are especially common at tectonically active basin margins (Posamentier and Allen, 1999; Williams and Graham, 2013). Any stratigraphic vestige of this former shelf and shoreline in the study area was eroded during later exhumation of the forearc margin stratigraphy.

\subsubsection{DRIVING FORCES OF NAKNEK FORMATION SEDIMENT SUPPLY AND BASE-LEVEL CHANGES}

Sediment supply and accommodation are the currency of sequence stratigraphy, but these factors are principally controlled by allogenic processes-tectonics, eustasy, and climate-that are complex, interrelated, and often difficult to interpret from the geologic record (Posamentier and Allen, 1999; Catuneanu, 2006; Catuneanu and others, 2009, 2011; Miall, 2010). In forearc basins, however, tectonism is generally credited as the dominant driver of third-order base-level cyclicity and stratigraphic architecture, with influences of eustatic change on million-year-scale stratigraphic sequences likely overwhelmed by tectonics (Miall, 2010). A comprehensive examination of these allogenic mechanisms in the context of the Naknek Formation is beyond the scope of this paper, but we preliminarily introduce several important considerations.

Our sequence analysis highlights probable tectonic effects on the stratigraphic evolution of the Naknek. Many of these signatures of tectonism relate to sediment supply. For example, the large volumes of coarse-grained, batholith-derived detritus that were flushed into the forearc during LST-1 and LST-2 suggest exhumation of the arc's plutonic roots and generation or maintenance of steep nonmarine gradients conducive to transporting these sediment loads to the shoreline. However, climate undoubtedly affected precipitation regimes that modulated Naknek sediment supply. For example, Wartes and Decker (2015) reported evidence in an along-strike equivalent to LST-1 of glacially influenced sedimentation in the Chisik Conglomerate Member of the Kamishak Bay area (see fig. 1). Warm-based glaciers in the Alaska-Aleutian Range batholith may have sculpted this provenance landscape (compare with Hallet and others, 1996) and set the scene for high-energy, flashy discharge environments that supplied abundant, coarse sediment to downdip LST-1 depositional systems. However, glaciation is not a prerequisite for such a sediment-supply regime, as fluvial processes may also yield rapid orogenic erosion rates-and in turn sediment yields to downdip depositional sites-in association with rock uplift (for example, Burbank, 2002; Koppes and Montgomery, 2009). In fact, Peizhen and others (2001) highlighted that climate change alone can increase sediment supply and caliber regardless of whether glaciers occur in a catchment. Notably, isotopic evidence for a Callovian-Oxfordian changing climate has been reported (for example, Dera and others, 2011), and any accompanying glaciation has eustatic-and thus accommodation-implications as well. Currently, however, there is not consensus in the literature regarding the occurrence or extent of a Middle-Late Jurassic transition glaciation (for example, Hallam, 2001; Dromart and others, 2003a, 2003b; Cecca and others, 2005; Alberti and others, 2012a, 2012b). Proponents of a Jurassic continental ice hypothesis suggest sea-level fall of 40-80 m during a late Callovian glacial maximum, with sea level rising into the late Oxfordian (Dromart and others, 2003a, 2003b). The timing of such a eustatic fall tentatively coincides with formation of BSFR/SB-1, and the hypothesized fall's magnitude suggests it may have played a critical role in the Chinitna FormationNaknek Formation transition on the northwest basin margin's shelf.

Despite the uncertainty regarding glacioeustatic change during establishment of BSFR/SB-1, this sequence boundary clearly reflects falling base level with zero to negative accommodation at the shoreline during earliest Naknek time. The Oxfordian stratigraphy that lies 
above this surface is typically more than $500 \mathrm{~m}$ thick, requiring a concomitant creation of accommodation following the dearth of nearshore accommodation demonstrated where BSFR/SB-1 crops out in the study area; that is to say, Oxfordian accommodation in the study area was chiefly created during Naknek time and not inherited from Chinitna Formation depositional systems. Although the LST-1 through HST base-level cycle defined above largely coincides with the rising part of the sea-level curve published by Dromart and others (2003a; their fig. 5), the hundreds of meters of accommodation created and filled during this time greatly exceeds any potential tens of meters of eustatic rise associated with the warming phase of a hypothesized Callovian-Oxfordian glacial cycle.

We suggest that tectonically driven subsidence in the forearc basin, which occurred at least in part contemporaneously with tectonically influenced exhumation and sediment influx from the arc, probably represents the main factor in Naknek accommodation creation during the Oxfordian. However, the LST-1 through HST (Oxfordian) base-level cycle was likely a composited curve, recording tectonics plus a subordinate eustatic signal ${ }^{7}$. Sea-level fall potentially factored prominently in establishment of BSFR/SB-1 by diminishing shelfal accommodation during the Callovian-Oxfordian transition. Convergent margin tectonic subsidence probably became increasingly dominant in generating Naknek accommodation through the Oxfordian, dwarfing any ostensible, contemporaneous glacioeustatic rise. Finally, climate change waned in the late Oxfordian, with the Kimmeridgian being a time of warm and stable climate (Dera and others, 2011) when an additional $900 \mathrm{~m}$ or more of Naknek Formation stratigraphy (LST-2 and overlying, not-yet-defined systems tracts of the Pomeroy Arkose Member) accumulated in the study area.

Delineating in detail the timing, nature, and relative contributions of the various allogenic drivers of base-level cyclicity in the Naknek Formation should include further comparison of this study's sequencestratigraphic framework with published oxygen isotope and seawater temperature curves for the Middle-Late Jurassic. Such an analysis may require new geochronologic constraints on Naknek members and systems tracts and/or reassessment of available faunal ages.
Additional complexities also arise in that orogenic feedback linkages occur among tectonics, climate, and topography (for example, Molnar and England, 1990; Burbank, 2002; Whipple, 2009), and forearc basins exhibit remarkably variable geometries and subsidence curves that reflect a variety of plate-margin-scale tectonic mechanisms (Dickinson, 1995; Xie and Heller, 2009; Noda, 2016). These and related topics require additional consideration, and syntheses of the tectonic, eustatic, and climatic implications of our Naknek Formation studies are forthcoming.

\section{IMPLICATIONS FOR POTENTIAL NAKNEK FORMATION RESERVOIRS IN THE COOK INLET SUBSURFACE}

This paper identifies paleobathymetric gradient domains of Naknek Formation depositional systems and emphasizes how transitions between these domains influenced erosion, bypass, and sediment accumulation in the context of base-level cyclicity and sediment supply. This stratigraphic framework sheds predictive light on lithofacies distribution in the Upper Jurassic stratigraphy, which regionally overlies the Middle Jurassic and/ or Late Triassic sources for the basin's oil and associated gas (for example, LePain and others, 2013), and has implications for hydrocarbon reservoirs in lower Cook Inlet. Oil-stained Naknek Formation sandstones in the Kamishak Bay area indicate reservoir potential in the unit (for example, Herriott and others, 2013), although exclusively Mesozoic petroleum plays in the basin are unproven (Decker, 2006; LePain and others, 2013).

The following section (1) discusses export of coarse sediment into the basin during deposition of the Naknek lowstand systems tracts, which bears on conventional reservoir prospectivity from a grain-size perspective; (2) summarizes previously published offshore subsurface data and its relevance to the distribution of Naknek lithologies and paleophysiography of the basin; and (3) highlights the potential impact of provenance variability and sediment routing on reservoir quality in the Naknek, and notes the importance of subsurface facies predictability regardless of commonly poor conventional reservoir quality parameters in the formation. 
4.1 Distribution of Coarse-Grained Facies in the Lowstand Systems Tracts

\subsubsection{LST-1}

LST-1 comprises sandstone and conglomerate in the outcrop belt, and these marginal- and shallow-marine depositional systems undoubtedly bypassed sand and gravel downdip. However, it remains enigmatic whether any of this bypassed sediment encountered a shelf-slope break beyond the outcrop belt and was shunted to a basin-floor setting. In other words, it is unclear if LST1 hosts a deep-water, sand-rich succession or if this systems tract simply fines and thins basinward along a relatively uniform or diminishing gradient depositional profile. Additional studies of this systems tract are in progress, and results from the ongoing work may yield insights into whether coarse deposits potentially accumulated in outer shelf and/or deep-water environments and lie in the subsurface today.

\subsubsection{LST-2}

The Pomeroy Arkose Member has long been recognized in the Iniskin-Tuxedni bays area (Martin, 1905; Martin and Katz, 1912; Moffit, 1927; Kirschner and Minard, 1949; Hartsock, 1954; Detterman and Hartsock, 1966), but the deep-marine affinity of this unit is not widely known, having only been documented in the public-domain literature by a few workers (Egbert, 1982; Wartes and others, 2013; LePain and others, 2013; this study). This report delineates deep-water depositional reaches in LST-2, including the lower part of the Pomeroy, that were prone to coarse-grained sedimentation and may have reservoir potential either along-strike or downdip in the subsurface.

Sand-prone canyon-fill successions broadly analogous to those described above are recognized throughout the world for their reservoir potential (for example, Cronin and Kidd, 1998; Stow and Mayall, 2000; Prather, 2003; Satur and others, 2005; Mayall and others, 2006; Di Celma, 2011; Jobe and others, 2011). The dominantly coarse-grained canyon fills of this study were probably supplied from sandy fluvial and shallow-marine environments (fig. 14; for example, compare with Posamentier and Kolla, 2003; Jobe and others, 2011). Sand-prone shelfal deposits with probable reservoir potential likely aggraded landward of the outcrop belt during normal regression lowstand conditions of LST-2 (for example, compare with Porębski and Steel,
2003; Covault and others, 2009) but were later eroded; however, contemporaneous along-strike shelfal settings may be preserved elsewhere. LST-1 of this study may constitute an older analog to this inferred LST-2 shelf, and a probable younger analog crops out in the Naknek Formation of Kamishak Bay (see below).

Reservoir facies may also occur in large-scale levee successions, which are prone to deep-water sand accumulation via overspilling processes (Posamentier and Kolla, 2003; Mayall and others, 2006; Dykstra and Kneller, 2007; Weimer and Slatt, 2007; Hubbard and others, 2008; Hansen and others, 2015). Note, however, that scale is an important consideration in this scenario, with paleobathymetric relief along the master levees in the Naknek and sediment gravity flow heights, sand-to-mud ratio, and density stratification character undoubtedly impacting the degree to which sandy beds developed in this setting (compare with Hansen and others, 2015). Regardless, sandstones are observed in the peak 3140 and Mount Pomeroy areas master levees, indicating the potential viability of this reservoir type. Furthermore, this stratigraphic element could have prograded into downdip settings during early LST-2 and thus may occur in the subsurface beyond the outcrop belt (compare with Hodgson and others, 2016).

The deep-water canyons of this study bypassed sediment to base-of-slope and basin-floor settings that hosted deep-water distributary depositional systems (fig. 14). These environments of deposition are globally recognized for their hydrocarbon reservoir prospectivity (for example, Mutti and Normark, 1987; Reading and Richards, 1994; Richards and Bowman, 1998; Richards and others, 1998; Weimer and Slatt, 2007; Macauley and Hubbard, 2013). Additionally, the interpreted clastic wedge of LST-2 basin-floor fans that onlapped the Snug Harbor slope (fig. 14) may be prone to stratigraphic trapping if overlying deep-water seal facies cap LST-2 (compare with Prather, 2003).

\subsection{Well Control}

A limited number of legacy exploration wells penetrate the Naknek Formation of lower Cook Inlet, and published data regarding these wells is scarce. The vertical Hawk 1 well (fig. 2) penetrated 3,143 m of Naknek Formation before drilling into underlying Middle Jurassic strata (Alaska Geological Society, 1985; LePain and others, 2013), but this apparent thickness is probably much greater than the true stratigraphic thickness of 
the unit due at least in part to structural thickening. The COST 1 well (fig. 2) ostensibly reached total depth in the Naknek Formation (Magoon, 1986a; compare to Alaska Geological Society, 1985), so a complete formation thickness is not clearly established for the well. Nevertheless, Magoon (1986b) reported that a 1,200-1,600-m-thick well interval at the bottom of COST 1 correlates to the Iniskin-Tuxedni bays region Naknek Formation, with 450-600 m of overlying Upper Jurassic strata correlated to the Tithonian Naknek of Kamishak Bay. Micropaleontological work on COST 1 material indicated that the Upper Jurassic interval encountered in the well is marginal to shallow marine, although possibly in part as deep as middle neritic (Magoon, 1986b; Turner, 1986).

It remains uncertain how the Naknek Formation of the Iniskin-Tuxedni bays areas correlates to the Upper Jurassic stratigraphy of COST 1. It is important to note, however, that our usage of deep water in this paper is a process-based definition (footnote 3 ) that reflects sedimentologic and stratigraphic interpretations of outcrops and does not refer to absolute water depth, contrasting with water-depth determinations for the COST 1 Naknek strata that are based on micropaleontological constraints. If, in fact, a Naknek interval that is age-equivalent to LST-2 of this study was penetrated in the COST 1 well and consists entirely of shallow-marine shelfal strata, the sand-rich Pomeroy of this study must pinch out between the outcrop belt and the well. An LST-2 basin-floor fan complex pinchout by downlap may be attributed to deceleration of low-efficiency sediment gravity flows beyond the base-of-slope gradient transition as reported above (also fig. 14). Additionally, the apparent absence of coeval deep-water strata at the COST 1 well may reflect a deep-marine depocenter or axial trough between the northwest basin margin and the well (fig. 2), suggesting basinward (southeastward) shoaling and a paleophysiographic basin configuration that is not well understood at this time. Future work focused on correlating the Iniskin-Tuxedni bays outcrop belt stratigraphy with the COST 1 well could provide additional insights into Late Jurassic forearc basin paleobathymetry and depositional systems.

\subsection{Additional Reservoir Considerations}

Naknek Formation sandstones were recently collected from the Iniskin-Tuxedni bays study area for determination of reservoir quality parameters. The samples are calcic plagioclase-rich, reflecting provenance from Talkeetna arc diorites and rendering a labile modal composition (Helmold and others, 2013). Limited conventional reservoir quality is reflected by low porosity and permeability results-typically less than 7 percent and less than 1 millidarcy, respectively-principally related to burial and zeolite cementation associated with albitization (Helmold and others, 2013; LePain and others, 2013). However, as suggested by Helmold and others (2013), variability in provenance terrane composition through time and space in the Talkeetna arc batholith may have yielded more mineralogically stable Naknek strata elsewhere in the basin, possibly resulting in better conventional reservoir quality than the Iniskin-Tuxedni bays area samples exhibit. Work by Helmold (2013) and Herriott and others (2013) indicates that shallow-marine Naknek Formation sandstones (Indecision Creek Member; Detterman and others, 1996) on the south shore of Kamishak Bay, which are notably locally oil stained (Magoon and others, 1975; Lyle and Morehouse, 1977; Stanley and others, 2013; Herriott and others, 2013), are somewhat more quartzose on average than the Naknek samples from the Iniskin-Tuxedni bays area; similar Naknek sandstones in the subsurface may have conventional reservoir potential. Interestingly, the Indecision Creek Member may in part represent a shelfal environment analogous to the inferred LST-2 shelf discussed above, although the member is younger (dominantly Tithonian; Detterman and others, 1996) than the lower Kimmeridgian Pomeroy (Detterman and Hartsock, 1966; Imlay, 1981).

The impacts of sandstone composition on conventional reservoir quality highlights the need to better understand how along-strike compositional variability of the Talkeetna arc batholith may have influenced the modal composition of Naknek sediments deposited in the forearc basin. However, it is a combination of source area composition (that is to say, geochemistry and mineralogy of plutons in the batholith) and sediment routing that is key to predicting where mineralogically stable sandstones, and thus potential conventional reservoirs, may occur in the Naknek Formation. The HST and LST-2 depositional model of figure 14 is an advancement in this respect, presenting a framework with source-to-sink sediment routing implications. Although figure 14 does not uniquely solve this problem, it does provide insights into various and potentially complex sediment routing pathways. As an example, sediment transport via longshore drift in conjunction 
with shelfal indentation by canyon heads can segment shallow-marine sediment dispersal systems and lead to the localized capture and shunting of sediments to deepwater settings (for example, Piper and Normark, 2001; Posamentier and Kolla, 2003; Covault and others, 2007; Sweet and Blum, 2016). In such a scenario, Pomeroy or coeval sand-rich deposits may have compositions that do not mirror the contemporaneously adjacent batholith and may even vary from sediments routed through a nearby sediment transport pathway and canyon system. Additionally, the degree, if any, to which deep-water basin axial transport occurred during the Late Jurassic is unknown, but further compositional variability in deep-marine Naknek sandstones may be influenced by this factor. This work serves as an impetus to further delineate ancient sediment transport pathways through depositional systems of the Naknek Formation that may provide specific source-to-sink constraints to improve our understanding of conventional reservoir quality potential in the unit. Plausible sediment routing scenarios should be integrated into exploration models of lower Cook Inlet.

Fracture-related migration pathways and/or fracturehosted hydrocarbons are also likely relevant to any petroleum system(s) that includes the Naknek. For example, oil seeps in the study area have long been recognized and are typically associated with fractures (Detterman and Hartsock, 1966; Blasko, 1976; Wartes and Herriott, 2014). Detterman and Hartsock (1966) also surmised that oil and gas shows in Iniskin Peninsula exploration wells were fracture controlled, and Rosenthal (in preparation) remarks that the highest fracture intensities in the Iniskin-Tuxedni bays area occur near the Bruin Bay fault system. Recent reports by Gillis and others (2013b) and Rosenthal and others (2015a, 2015b, 2016) stem from fracture characterization studies in lower Cook Inlet that aim to address fractured reservoir potential of the basin's Mesozoic stratigraphy, including the Naknek Formation, which in outcrop has prominent, widespread, meso-scale fracture sets and in thin section contains micro-fractures (Helmold and others, 2013). Rosenthal and others (2015a, 2015b, 2016) preliminarily reported that fracture intensities in Mesozoic strata of the Iniskin Peninsula and surrounding areas correlate with grain size, with finer-grained strata having higher fracture intensities than coarser-grained strata. However, ongoing work by Rosenthal (in preparation) indicates that a grain-size correlation with fracture intensity is apparently lacking in the Iniskin-Tuxedni bays study area, although the author notes that some lithologic parameters may have unrecognized relations to fracture characteristics (for example, compare with Nelson, 2001). Nevertheless, these recent fracture studies demonstrate the relevance of structural and stratigraphic inputs in establishing a fractured reservoir model for the Naknek.

Other considerations regarding potential Naknek Formation reservoirs include the degree of sorting in sandstones and timing of oil charge. As a possible analog for a tight reservoir play in the Naknek, Wartes and Herriott (2015) documented matrix-hosted oil in a poorly sorted, low-permeability(?) Chinitna Formation sandstone that crops out on the south shore of Chinitna Bay. Those authors hypothesized that argillaceous Jurassic sandstones may have maintained some degree of primary reservoir quality for longer during burial than did well-sorted strata, with the latter initially serving as preferential conduits for flow of diagenetic fluids and early cementation. It is thus possible that poorly sorted Naknek Formation sandstones may serve as tight, low-permeability reservoirs in the subsurface (see also LePain and others, 2013). Additionally, Decker (2006) highlighted that strong, early oil charge of Mesozoic sandstones in Cook Inlet, if it occurred, could have retarded porosity-destroying cementation during subsequent burial to greater depths, further demonstrating that numerous scenarios exist where oil and/or gas may be hosted in the Jurassic stratigraphy. Notably, a recent U.S. Geological Survey assessment of undiscovered oil and gas in Cook Inlet delineated two Mesozoic assessment units, although they are generally unexplored (Stanley and others, 2011a, 2011b). Regardless of the play type, Naknek Formation depositional systems and facies distribution remain important considerations for petroleum exploration in Cook Inlet.

\section{SUMMARY AND CONCLUSIONS}

The Naknek Formation in the Iniskin-Tuxedni bays region comprises four members deposited in shallow- to deep-marine environments of the Late Jurassic (early Oxfordian-early Kimmeridgian) Cook Inlet forearc basin (in ascending order): Chisik Conglomerate (fan delta), lower sandstone (inner shelf), Snug Harbor Siltstone (outer shelf and slope), and Pomeroy Arkose (base of slope and basin floor). Field studies led to the 
recognition of three seismic-scale stratigraphic elements associated with the deep-water Snug Harbor Siltstone and Pomeroy Arkose Members in the Chisik Island, Hickerson Lake, and Mount Pomeroy areas. Sedimentologic, stratigraphic, and geologic mapping-based observations at these localities indicate tabular-bedded Snug Harbor successions of slope affinity (locally identified as $J n s_{1}$ ) were incised and host channelized Snug Harbor $\left(\mathrm{Jns}_{2}\right)$ and Pomeroy $\left(\mathrm{Jnp}_{1}\right)$ intervals. Hundreds of meters of lithostratigraphic relief across kilometerscale lateral extents are evident in these areas, where field relations indicate establishment and filling of three submarine canyons as part of a deep-water aspect of the Naknek Formation that evolved during late Oxfordian(?)-early Kimmeridgian. We interpret that these Naknek canyons were established by erosive sediment gravity flows, with incision driven by allogenic forcing; stratigraphic relief along these incisions may locally exceed $260 \mathrm{~m}$. Further confinement of canyon-floor channel belts was provided by the growth of thick, leveed master margins that may have total compacted thicknesses of $250 \mathrm{~m}$ or greater. Early canyon fill $\left(\mathrm{Jns}_{2}\right)$ locally recorded deposition from the coarsest-grained bedload (conglomerate and sandstone) and probable dilute tails (siltstone and associated sandstone) of sediment gravity flows during a bypass-dominated phase of canyon evolution. Canyon-associated deep-water depositional systems later transitioned to a channelized-aggradational regime along canyon axes $\left(\mathrm{Jnp}_{1}\right)$. Finally, the broadly tabular, amalgamated, thick packages of $\mathrm{Jnp}_{2}$ strata were deposited, likely recording kilometer-scale, coalescing distributary lobes that aggraded beyond canyon mouths and formed basin-floor fans with radii of $15 \mathrm{~km}$ or greater. Overall depositional trends in the canyon successions reflect upsection reduction in gradients along canyon axes and reduced bypass, suggesting a return to above-seafloor equilibrium profiles for near-canyon-mouth environments at the base of slope. Some degree of degradation that may be beyond the scale of autocyclicity is apparent at intra-canyon fill $\mathrm{Jns}_{2}-\mathrm{Jnp}_{1}$ contacts, but the larger-scale trend of upsection diminishing gradient along canyon axes is dominant. Sand-choked depositional systems of Pomeroy-dominantly recorded by $\mathrm{Jnp}_{2}$ - ultimately backstepped and onlapped the inherited paleobathymetric expression of the Snug Harbor slope, and canyon mouths retreated farther upslope as arkosic sediment continued to spill onto the basin floor. Comparable deep-marine stratigraphic relations are best known from seismic reflection datasets and are rarely well-expressed or recognized in outcrop; the paleocanyons of this study are among the best outcrop examples known worldwide.

We propose a sequence-stratigraphic framework for the Naknek Formation that identifies candidate sequencestratigraphic surfaces, enveloping systems tracts and reflecting pivotal changes in base level and sediment supply. The basal, shallow-marine Naknek Formation members-Chisik Conglomerate (fan delta) and lower sandstone (inner shelf) — constitute a lowstand systems tract (LST-1) that overlies the Middle Jurassic Chinitna Formation along a locally erosional sequence boundary identified as a basal surface of forced regression (BSFR/SB-1). An overlying transgressive surface marks onset of TST in the lower Snug Harbor (outer shelf), which is capped by a maximum flooding surface at the base of a mid Snug Harbor resistant interval. The upper Snug Harbor (slope) overlies this maximum flooding surface and is identified as HST, which was in turn terminated by establishment of a second Naknek Formation sequence boundary (BSFR/SB-2). BSFR/ $\mathrm{SB}-2$ is a deep-water basal surface of forced regression that the canyons of this study were incised along. The youngest, stratigraphically distinct Snug Harbor (canyon-associated $\mathrm{Jns}_{2}$ and Jns master-levee deposits) and lower Pomeroy (base of slope and basin floor; locally canyon-associated) are deep-water aspects of a second lowstand systems tract (LST-2) in the Naknek. This proposed sequence-stratigraphic framework indicates that a complete, third-order stratigraphic sequence occurs in the Chisik-lower sandstone-HST Snug Harbor, with a renewed cycle of sedimentation in LST-2 Snug Harbor and Pomeroy that overlie the canyons-associated sequence boundary (BSFR/SB-2).

Two sediment-supply-dominated episodes were recorded by forced through normal regressions of LST-1 and LST-2. These lowstand systems tracts may in part reflect slip along the Bruin Bay fault system and increased sediment supply to the basin, although the fault system's slip history is not yet well constrained. TST and HST were deposited during a period of rising base level where the alternating balance between accommodation creation (favored during TST) and sediment supply (favored during HST) dictated shoreline trajectories. We interpret establishment of a shelf-slope-basin-floor depositional dip profile in the study area by progradation of clinoforms during the HST, setting the scene for incipient canyon development along the Snug Harbor 
slope, aggradation of canyon-bounding levees, and accumulation of coarse-grained detritus of $\mathrm{Jns}_{2}$ and lower Pomeroy (including $\mathrm{JnP}_{1}$ and $\mathrm{Jnp}_{2}$ ) as deep-water basinal elements of LST-2. Canyon-associated and overlying depositional systems of LST-2 ultimately rendered a coarse clastic wedge at the slope-basin floor transition that onlapped the Snug Harbor slope and likely thins by downlap basinward of the outcrop belt.

This study delineates stratigraphic changes reflected in the rock record and discusses them in terms of accommodation and sediment supply, but these factors are themselves controlled by the interplay among tectonics, eustasy, and climate. Several lines of evidence preliminarily shed light on how these allogenic controls influenced basin-fill architecture. For example, inception of Naknek deposition during the early Oxfordian marks regionally widespread delivery of coarse, batholithic detritus into the forearc basin, suggesting exhumation of the Talkeetna arc's plutonic roots and tectonics-driven sediment supply. Evidence of a glacial influence on Naknek sedimentation has been reported in the Chisik Conglomerate Member southwest of the study area and has implications for modulation of sediment-supply regimes to marine settings of LST-1 but is not essential to our interpretation. Some published isotope studies indicate Callovian-Oxfordian climate change and accompanying continental ice formation, but the existence and extent of this glaciation remain uncertain. Nevertheless, it is worth noting that a hypothesized sea-level fall of 40-80 $\mathrm{m}$, with a glacial maximum during late Callovian, tentatively coincides with the formation of BSFR/SB-1 and is of a magnitude that may have strongly influenced the transition in shelf facies of the Chinitna and Naknek Formations. However, requisite accommodation creation recorded by the Oxfordian Naknek stratigraphy exceeds any apparently coeval glacioeustatic rise by an order of magnitude. Furthermore, an additional $900 \mathrm{~m}$ or more of Naknek stratigraphy accumulated in the study area during the early Kimmeridgian, which marked a return to a probable warm and stable climate. We thus suggest that glacioeustatic fall at the Chinitna-Naknek transition may have played an important role in the basin's stratigraphic evolution, with subsequent Naknek Formation accommodation creation primarily underwritten by subsidence related to convergent margin tectonics and subordinately influenced by eustasy.
Cook Inlet is an underexplored petroleum province that is economically vital to south-central Alaska. The canyon-associated deep-water depositional systems and sequence-stratigraphic framework described by this study yield improved predictability for the distribution of potential hydrocarbon reservoir facies in the Upper Jurassic stratigraphy of the basin. Coarse detritus was shed into marine settings of the forearc during deposition of the lowstand systems tracts, although the distal extents of LST-1 are not yet well defined. Shelf (inferred), canyon axis, master levee, and base-of-slope to basin-floor settings of LST-2 were in part prone to accumulating sand and gravel with potential to form hydrocarbon reservoirs. Although arkosic sandstones of the Naknek Formation often have low conventional reservoir quality in the outcrop belt, a better understanding of the compositional variability of the provenance area and sediment routing pathways are keys to determining whether and where conventional reservoir quality may occur in the unit. Regardless, understanding depositional systems and distribution of lithologies in the Naknek Formation is relevant to exploration models that consider numerous play types, including fractured and/or tight, low-permeability reservoirs in Cook Inlet. Ongoing work aims to further delineate the Naknek Formation's stratigraphic evolution in the context of tectonics, climate, eustasy, and petroleum systems in the Late Jurassic arc-forearc region of southern Alaska.

\section{ACKNOWLEDGMENTS}

The State of Alaska provided primary funding for this study. The U.S. Geological Survey's National Cooperative Geologic Mapping Program (NCGMP) supported geologic mapping during the 2013 and 2015 field seasons through STATEMAP (award numbers G13AC00157 and G15AC00199). Land access was permitted by Lake Clark National Park \& Preserve, Cook Inlet Region, Inc., and the Alaska Native village corporations of Chickaloon, Knik, Ninilchik, Salamatof, Seldovia, and Tyonek.

We recognize our colleagues at the Alaska Division of Geological \& Geophysical Surveys, Alaska Division of Oil and Gas, and U.S. Geological Survey who participated in the lower Cook Inlet research program, including Dave LePain, Bob Gillis, Rick Stanley, Ken Helmold, Paul Betka, Diane Shellenbaum, Laura Gregersen, Nina 
Harun, Jacob Rosenthal, Kate Bull, Alicja Wypych, Shaun Peterson, Bekah Tsigonis, Mary Maley, Rachel Frohman, and Paul Wilcox. Bob Gillis led many field campaigns in the area and secured funding for geologic mapping integral to this study. Bob Swenson, Dave LePain, and Steve Masterman provided invaluable leadership at DGGS.

We appreciate the hospitality and accommodations at Alaska Homestead Lodge, Pile Bay, Bear Mountain Lodge, and Snug Harbor Wilderness Lodge. We flew with many excellent pilots during the course of this work and especially extend our gratitude to helicopter pilot Merlin Handley: Thanks for the ride, Spanky.

Paul Betka, Merlin Handley, Bekah Tsigonis, Jacob Rosenthal, Ken Helmold, the doctors and nurses at South Peninsula Hospital, Alaska Spine Institute, and Regions Hospital, and Denise Jerome, P.T., helped make this paper possible. TMH recognizes co-authors MAW and PLD; his wife, Mareca Guthrie; and family and friends for the same. A most sincere thank you to all.

We thank Richard Lease for discussions regarding the relations among glaciation, tectonics, erosion, and sedimentation. Dave LePain generously shared his knowledge of sequence stratigraphy, deep-water processes, and the Pomeroy Arkose Member. Thorough reviews by Dave Houseknecht and Dave LePain improved the manuscript.

\section{REFERENCES CITED}

Alaska Geological Society, 1985, Stratigraphic correlation section, Cape Douglas to Ninilchik, in Cook Inlet Basin Structure and Stratigraphic Sections: Anchorage, Alaska Geological Society CD, Item \#SA02, one sheet, vertical scale 1"=500 ft. http:// www.alaskageology.org/pubstratigraphic.html

Alberti, Matthias, Fürsich, F.T., and Pandey, D.K., 2012a, The Oxfordian stable isotope record $\left(\delta^{18} \mathrm{O}\right.$, $\delta^{13} \mathrm{C}$ ) of belemnites, brachiopods, and oysters from the Kachchh Basin (western India) and its potential for palaeoecologic, palaeoclimatic, and palaeogeographic reconstructions: Palaeogeography, Palaeoclimatology, Palaeoecology, v. 344-345, p. 49-68. http://doi.org/10.1016/j.palaeo.2012.05.018

Alberti, Matthias, Fürsich, F.T., Pandey, D.K., and Ramkumar, M., 2012b, Stable isotope analyses of belemnites from the Kachchh Basin, western IndiaPaleoclimatic implications for the Middle to Late Jurassic transition: Facies, v. 58, no. 2, p. 261-278. http://doi.org/10.1007/s10347-011-0278-9
Bain, H.A., and Hubbard, S.M., 2016, Stratigraphic evolution of a long-lived submarine channel system in the Late Cretaceous Nanaimo Group, British Columbia, Canada: Sedimentary Geology, v. 337, p. 113132. http://doi.org/10.1016/j.sedgeo.2016.03.010

Betka, P.M., and Gillis, R.J., 2014a, Preliminary kinematic evidence for right-lateral slip along a system of steeply-dipping faults in the hanging wall of the Bruin Bay fault, Iniskin Peninsula, lower Cook Inlet, Alaska, in Gillis, R.J., ed., Cook Inlet program 2013 field studies-Observations and preliminary interpretations from new 1:63,360-scale geologic mapping of the Iniskin Peninsula, lower Cook Inlet, Alaska: Alaska Division of Geological \& Geophysical Surveys Preliminary Interpretive Report 2014-2-4, p. 17-22. http://doi.org/10.14509/27309

Betka, P.M., and Gillis, R.J., 2014b, Preliminary characterization of brittle deformation on the Iniskin Peninsula-Implications for the kinematic history of the Bruin Bay fault system, lower Cook Inlet, Alaska: Alaska Division of Geological \& Geophysical Surveys Preliminary Interpretive Report 2014-5, 14 p. http://doi.org/10.14509/29130

Betka, P.M., and Gillis, R.J., 2015, The superposition of strike-slip and reverse-slip faults in the Bruin Bay fault system, Ursus Head, lower Cook Inlet, in Wartes, M.A., ed., Energy-related studies during the 2014 field season, western Cook Inlet, Alaska: Alaska Division of Geological \& Geophysical Surveys Preliminary Interpretive Report 2015-5-2, p. 5-8. http:// doi.org/10.14509/29457

Betka, P.M., and Gillis, R.J., 2016, Observations on the Bruin Bay fault system between Chinitna and Tuxedni bays, Cook Inlet, Alaska, in Herriott, T.M., Petroleum-related geologic studies in lower Cook Inlet during 2015, Iniskin-Tuxedni region, south-central Alaska: Alaska Division of Geological \& Geophysical Surveys Preliminary Interpretive Report 2016-1-10, p. 73-78. http://doi. org/10.14509/29544

Blasko, D.P., 1976, Oil and gas seeps in Alaska, Alaska Peninsula, western Gulf of Alaska: U.S. Bureau of Mines Report of Investigations 8122, 80 p. http:// www.dggs.alaska.gov/pubs/id/29150

Bradley, D.C., Kusky, T.M., Haeussler, P.J., Karl, S.M., and Donley, D.T., 1999, Geologic map of the Seldovia Quadrangle, south-central Alaska: U.S. Geological Survey Open-File Report 99-18, 1 sheet, scale 1:250,000. https://pubs.usgs.gov/of/1999/of99-018/

Brunt, R.L., Di Celma, C.N., Hodgson, D.M., Flint, S.S., Kavanagh, J.P., and van der Merwe, W.C., 2013, Driving a channel through a levee when the levee is high-An outcrop example of submarine downdip entrenchment: Marine and Petroleum Geology, 
v. 41, p. 134-145. http://doi.org/10.1016/j.marpetgeo.2012.02.016

Burbank, D.W., 2002, Rates of erosion and their implications for exhumation: Mineralogical Magazine, v. 66, no. 1, p. 25-52. http://doi. org/10.1180/0026461026610014

Catuneanu, Octavian, 2002, Sequence stratigraphy of clastic systems-Concepts, merits, and pitfalls: Journal of African Earth Sciences, v. 35, no. 1, p. 1-43. http://doi.org/10.1016/S0899-5362(02)00004-0

Catuneanu, Octavian, 2006, Principles of Sequence Stratigraphy: Amsterdam, Elsevier, 375 p.

Catuneanu, Octavian, Abreu, V., Bhattacharya, J.P., Blum, M.D., Dalrymple, R.W., Eriksson, P.G., Fielding, C.R., Fisher, W.L., Galloway, W.E., Gibling, M.R., Giles, K.A., Holbrook, J.M., Jordan, R., Kendall, C.G.St.C., Macurda, B., Martinsen, O.J., Miall, A.D., Neal, J.E., Nummedal, Dag, Pomar, L., Posamentier, H.W., Pratt, B.R., Sarg, J.F., Shanley, K.W., Steel, R.J., Strasser, A., Tucker, M.E. and Winker, C., 2009, Towards the standardization of sequence stratigraphy: Earth-Science Reviews, v. 92, no. 1-2, p. 1-33. http://doi.org/10.1016/j.earscirev.2008.10.003

Catuneanu, Octavian, Galloway, W.E., Kendall, C.G.St.C., Miall, A.D., Posamentier, H.W., Strasser, André, and Tucker, M.E., 2011, Sequence stratigraphy-Methodology and nomenclature: Newsletters on Stratigraphy, v. 44, no. 3, p. 173-245. http://doi. org/10.1127/0078-0421/2011/0011

Catuneanu, Octavian, and Zecchin, Massimo, 2016, Unique vs. non-unique stratal geometriesRelevance to sequence stratigraphy: Marine and Petroleum Geology, v. 78, p. 184-195. http://doi. org/10.1016/j.marpetgeo.2016.09.019

Cecca, F., Garin, B.M., Marchand, D., Lathuiliere, B., and Bartolini, A., 2005, Paleoclimatic control of biogeographic and sedimentary events in Tethyan and peri-Tethyan areas during the Oxfordian (Late Jurassic): Palaeogeography, Palaeoclimatology, Palaeoecology, v. 222, no. 1-2, p. 10-32. http://doi. org/10.1016/j.palaeo.2005.03.009

Clark, J.D., and Pickering, K.T., 1996, Submarine Channels-Processes and Architecture: London, Vallis Press, $231 \mathrm{p}$.

Clift, P.D., Draut, A.E., Kelemen, P.B., Blusztajn, Jerzy, and Greene, Andrew, 2005, Stratigraphic and geochemical evolution of an oceanic arc upper crustal section-The Jurassic Talkeetna volcanic formation, south-central Alaska: Geological Society of America Bulletin, v. 117, no. 7-8, p. 902-925. http:// doi.org/10.1130/B25638.1

Cohen, K.M., Finney, S.C., Gibbard, P.L., and Fan, J.-X., 2013 (updated), The ICS International Chronostratigraphic Chart: Episodes 36, p. 199-204. www.stratigraphy.org/icschart/chronostratchart2014-02.pdf

Compton, R.R., 1985, Geology in the Field: New York, John Wiley \& Sons, 398 p.

Covault, J.A., Normark, W.R., Romans, B.W., and Graham, S.A., 2007, Highstand fans in the California borderland-The overlooked deep-water depositional systems: Geology, v. 35, no. 9, p. 783-786. http://doi.org/10.1130/G23800A.1

Covault, J.A., Romans, B.W., and Graham, S.A., 2009, Outcrop expression of a continental-margin-scale shelf-edge delta from the Cretaceous Magallanes Basin, Chile: Journal of Sedimentary Research, v. 79, no. 7, p. 523-539. http://doi.org/10.2110/ jsr.2009.053

Cronin, B.T., and Kidd, R.B., 1998, Heterogeneity and lithotype distribution in ancient deep-sea canyonsPoint Lobos deep-sea canyon as a reservoir analogue: Sedimentary Geology, v. 115, no. 1-4, p. 315-349. http://doi.org/10.1016/S0037-0738(97)00099-7

Decker, P.L., 2006, A brief overview of Alaska petroleum systems: Alaska Division of Geological \& Geophysical Surveys Newsletter 2006-2, p. 1-6. http://doi. org/10.14509/15750

Dera, Guillaume, Brigaud, Benjamin, Monna, Fabrice, Laffont, Rémi, Pucéat, Emmanuelle, Deconinck, J.-F., Pellenard, Pierre, Joachimski, M.M., and Durlet, Christophe, 2011, Climatic ups and downs in a disturbed Jurassic world: Geology, v. 39, p. 215-218. http://doi.org/10.1130/G31579.1

Detterman, R.L., and Hartsock, J.K., 1966, Geology of the Iniskin-Tuxedni region, Alaska: U.S. Geological Survey Professional Paper 512, 78 p., 6 sheets, scale 1:63,360. https://pubs.er.usgs.gov/publication/pp512

Detterman, R.L., and Reed, B.L., 1980, Stratigraphy, structure, and economic geology of the Iliamna Quadrangle, Alaska: U.S. Geological Survey Bulletin 1368-B, p. B1-B86, 1 sheet, scale 1:250,000. https:// pubs.er.usgs.gov/publication/b1368B

Detterman, R.L., Case, J.E., Miller, J.W., Wilson, F.H., and Yount, M.E., 1996, Stratigraphic framework of the Alaska Peninsula: U.S. Geological Survey Bulletin 1969-A, 74 p. https://pubs.er.usgs.gov/publication/b1969A

Di Celma, Claudio, 2011, Sedimentology, architecture, and depositional evolution of a coarse-grained submarine canyon fill from the Gelasian (early Pleistocene) of the Peri-Adriatic basin, Offida, central Italy: Sedimentary Geology, v. 238, no. 3-4, p. 233-253. http://doi.org/10.1016/j.sedgeo.2011.05.003

Dickinson, W.R., 1995, Forearc basins, in Busby, C.J., and Ingersoll, R.V., eds., Tectonics of Sedimentary Basins: Blackwell Scientific, p. 221-261. 
Dromart, Gilles, Garcia, J.-P., Gaumet, Fabrice, Picard, Stephanie, Rousseau, Mathieu, Atrops, Francois, Lécuyer, Christophe, and Sheppard, S.M.F., 2003a, Perturbation of the carbon cycle at the Middle/Late Jurassic transition-Geological and geochemical evidence: American Journal of Science, v. 303, no. 8, p. 667-707. http://doi.org/10.2475/ajs.303.8.667

Dromart, Gilles, Garcia, J.-P., Picard, Stephanie, Atrops, Francois, Lécuyer, Christophe, and Sheppard, S.M.F., 2003b, Ice age at the Middle-Late Jurassic transition?: Earth and Planetary Science Letters, v. 213, no. 3-4, p. 205-220. http://doi.org/10.1016/S0012821X(03)00287-5

Dykstra, Mason, and Kneller, Ben, 2007, Canyon San Fernando, Mexico-A deep-water, channel-levee complex exhibiting evolution from submarine canyon-confined to unconfined, in Nilsen, T.H., Shew, R.D., Steffens, G.S., and Studlick, J.R.J., eds., Atlas of Deepwater Outcrops: American Association of Petroleum Geologists Studies in Geology, v. 56, p. 226-230.

Egbert, R.M., 1982, Sedimentology and petrography of the Middle and Upper Jurassic rocks in the Tuxedni Bay area, Cook Inlet Alaska: San Jose, CA, San Jose State University, Master of Science thesis, 128 p.

Fildani, Andrea, Hubbard, S.M., Covault, J.A., Maier, K.L., Romans, B.W., Traer, Miles, and Rowland, J.C., 2013, Erosion at inception of deep-sea channels: Marine and Petroleum Geology, v. 41, p. 48-61. http:// doi.org/10.1016/j.marpetgeo.2012.03.006

Fisher, M.A., and Magoon, L.B., 1978, Geologic framework of lower Cook Inlet, Alaska: American Association of Petroleum Geologists Bulletin, v. 62, no. 3, p. 373-402.

Flint, S.S., Hodgson, D.M., Sprague, A.R., Brunt, R.L., Van der Merwe, W.C., Figueiredo, J., Prélat, A., Box, D., Di Celma, C., and Kavanagh, J.P., 2011, Depositional architecture and sequence stratigraphy of the Karoo basin floor to shelf edge succession, Laingsburg depocentre, South Africa: Marine and Petroleum Geology, v. 28, p. 658-674. http://doi. org/10.1016/j.marpetgeo.2010.06.008

Galloway, W.E., 1998, Siliciclastic slope and base-ofslope depositional systems-Component facies, stratigraphic architecture, and classification: American Association of Petroleum Geologists Bulletin, v. 82 , no. 4 , p. 569-595.

Galloway, W.E., and Hobday, D.K., 1996, Terrigenous Clastic Depositional Systems-Applications to Fossil Fuel and Groundwater Resources (second edition): Berlin, Springer-Verlag, 489 p.

Gillis, R.J., ed., 2013, Overview of 2012 field studies-Upper Alaska Peninsula and west side of lower
Cook Inlet, Alaska: Alaska Division of Geological \& Geophysical Surveys Preliminary Interpretive Report 2013-1, 48 p. http://doi.org/10.14509/24824 Gillis, R.J., ed., 2014, Cook Inlet program 2013 field studies-Observations and preliminary interpretations from new 1:63,360-scale geologic mapping of the Iniskin Peninsula, lower Cook Inlet, Alaska: Alaska Division of Geological \& Geophysical Surveys Preliminary Interpretive Report 2014-2, 31 p. http://doi.org/10.14509/27303

Gillis, R.J., 2016, Discovery of a new sandstone with residual oil in Maastrichtian(?) strata at Shelter Creek, lower Cook Inlet, Alaska, in Herriott, T.M., ed., Petroleum-related geologic studies in lower Cook Inlet during 2015, Iniskin-Tuxedni region, south-central Alaska: Alaska Division of Geological \& Geophysical Surveys Preliminary Interpretive Report 2016-1-7, p. 51-58. http://doi.org/10.14509/29541

Gillis, R.J., Maley, M.R., Frohman, R.A., and Peterson, C.S., 2013b, Fracture studies in Upper Cretaceous and Upper Jurassic strata on the upper Alaska Peninsula and lower Cook Inlet, in Gillis, R.J., ed., Overview of 2012 field studies-Upper Alaska Peninsula and west side of lower Cook Inlet, Alaska: Alaska Division of Geological \& Geophysical Surveys Preliminary Interpretive Report 2013-1D, p. 13-17. http://doi.org/10.14509/24847

Gillis, R.J., Swenson, R.F., Wartes, M.A., and Frohman, R.A., 2013a, Reconnaissance investigations of the Bruin Bay fault system along the western margin of lower Cook Inlet and upper Alaska Peninsula, in Gillis, R.J., ed., Overview of 2012 field studies-Upper Alaska Peninsula and west side of lower Cook Inlet, Alaska: Alaska Division of Geological \& Geophysical Surveys Preliminary Interpretive Report 2013-1G, p. 33-37. http://doi.org/10.14509/24850

Gillis, R.J., Wartes, M.A., Herriott, T.M., Bull, K.F., Decker, P.L., and Betka, P.M., 2014, Overview of new 1:63,360-scale geologic mapping of the Iniskin Peninsula, lower Cook Inlet, Alaska, in Gillis, R.J., ed., Cook Inlet program 2013 field studiesObservations and preliminary interpretations from new 1:63,360-scale geologic mapping of the Iniskin Peninsula, lower Cook Inlet, Alaska: Alaska Division of Geological \& Geophysical Surveys Preliminary Interpretive Report 2014-2-1, p. 3-6, http://doi. org/10.14509/27306

Hallam, Anthony, 2001, A review of the broad pattern of Jurassic sea-level changes and their possible causes in the light of current knowledge: Palaeogeography, Palaeoclimatology, Palaeoecology, v. 167, no. 1-2, p. 23-37. http://doi.org/10.1016/S0031$\underline{0182(00) 00229-7}$ 
Hallet, B., Hunter, L., and Bogen, J., 1996, Rates of erosion and sediment evacuation by glaciers $-\mathrm{A}$ review of field data and their implications: Global and Planetary Change, v. 12, no. 1-4, p. 213-235. http:// doi.org/10.1016/0921-8181(95)00021-6

Hansen, L.A.S., Callow, R.H.T., Kane, I.A., Gamberi, Fabiano, Rovere, Marzia, Cronin, B.T., and Kneller, B.C., 2015, Genesis and character of thin-bedded turbidites associated with submarine channels: Marine and Petroleum Geology, v. 67, p. 852-879. http:// doi.org/10.1016/j.marpetgeo.2015.06.007

Hartsock, J.K., 1954, Geologic map and structure sections of the Iniskin Peninsula and adjacent area of Alaska: U.S. Geological Survey Open-File Report 54-118, 1 p., 3 sheets. http://www.dggs.alaska.gov/ pubs/id/10502

Helmold, K.P., 2013, Reservoir quality of sandstones in the Naknek and Kaguyak Formations-Field observations, in Gillis, R.J., ed., Overview of 2012 field studies-Upper Alaska Peninsula and west side of lower Cook Inlet, Alaska: Alaska Division of Geological \& Geophysical Surveys Preliminary Interpretive Report 2013-1C, p. 11-12. http://doi. org/10.14509/24846

Helmold, K.P., LePain, D.L., Wilson, M.D., and Peterson, C.S., 2013, Petrology and reservoir potential of Tertiary and Mesozoic sandstones, Cook Inlet, Alaska-A preliminary analysis of outcrop samples collected during 2007-2010 field seasons: Alaska Division of Geological \& Geophysical Surveys Preliminary Interpretive Report 2013-5, 34 p. http:// doi.org/10.14509/25035

Herriott, T.M., ed., 2016, Petroleum-related geologic studies in lower Cook Inlet during 2015, IniskinTuxedni region, south-central Alaska: Alaska Division of Geological \& Geophysical Surveys Preliminary Interpretive Report 2016-1, 78 p. http://doi. org/10.14509/29532

Herriott, T.M., and Wartes, M.A., 2014, Geologicmapping-based observations of the Middle Jurassic Chinitna Formation and Upper Jurassic Naknek Formation in the Tilted Hills, Iniskin Peninsula, Cook Inlet, Alaska: Alaska Division of Geological \& Geophysical Surveys Preliminary Interpretive Report 2014-3, 23 p. http://doi.org/10.14509/27305 Herriott, T.M., Decker, P.L., and Wartes, M.A., 2015a, Evidence of a submarine canyon in the Snug Harbor Siltstone and Pomeroy Arkose Members, Naknek Formation, south-central Alaska-Implications for the distribution of coarse-grained sediment in Upper Jurassic strata of Cook Inlet, in Wartes, M.A., ed., Energy-related studies during the 2014 field season, western Cook Inlet, Alaska: Alaska Division of Geological \& Geophysical Surveys Preliminary Interpretive Report 2015-5-9, p. 57-62. http://doi. org/10.14509/29464

Herriott, T.M., Wartes, M.A., and Decker, P.L., 2015b, Deep-water canyons in the Snug Harbor Siltstone and Pomeroy Arkose Members, Naknek Formation, Alaska-New insights into the sequence stratigraphy of the Late Jurassic Cook Inlet forearc basin [presentation]: Geological Society of America, Cordilleran Section Annual Meeting, May 11-13, 2015, Anchorage, Alaska: Alaska Division of Geological \& Geophysical Surveys, 37 p. http://doi. org/10.14509/29443

Herriott, T.M., Wartes, M.A., and Decker, P.L., 2015c, Sequence stratigraphic framework of the Upper Jurassic Naknek Formation, Cook Inlet forearc basin, south-central Alaska [presentation]: Alaska Geological Society, November 17, 2015, Anchorage, Alaska: Alaska Division of Geological \& Geophysical Surveys, 73 p. http://doi.org/10.14509/29551

Herriott, T.M., Wartes, M.A., and Decker, P.L., 2016a, Record of a Late Jurassic deep-water canyon at Chisik Island, south-central Alaska-Further delineation of Naknek Formation depositional systems in lower Cook Inlet, in Herriott, T.M., ed., Petroleumrelated geologic studies in lower Cook Inlet during 2015, Iniskin-Tuxedni region, south-central Alaska: Alaska Division of Geological \& Geophysical Surveys Preliminary Interpretive Report 2016-1-6, p. 45-49. http://doi.org/10.14509/29540

Herriott, T.M., Wartes, M.A., Decker, P.L., and Harun, N.T., 2016b, Preliminary stratigraphic architecture of the Middle Jurassic Paveloff Siltstone Member, Chinitna Formation, Tuxedni Bay area, Cook Inlet, Alaska, in Herriott, T.M., ed., Petroleum-related geologic studies in lower Cook Inlet during 2015, Iniskin-Tuxedni region, south-central Alaska: Alaska Division of Geological \& Geophysical Surveys Preliminary Interpretive Report 2016-1-5, p. 39-44. http://doi.org/10.14509/29539

Herriott, T.M., Wartes, M.A., Stanley, R.G., Lillis, P.G., Helmold, K.P., Decker, P.L., and Gillis, R.J., 2013, Oil-stained sandstones of the Upper Jurassic Naknek Formation and Upper Cretaceous Kaguyak Formation, Kamishak Bay area, lower Cook Inlet, Alaska [poster]: AAPG Pacific Section Meeting, Monterey, CA, April 23, 2013: Alaska Division of Geological \& Geophysical Surveys, 1 sheet. http:// doi.org/10.14509/25139

Hodgson, D.M., Di Celma, C.N., Brunt, R.L., and Flint, S.S., 2011, Submarine slope degradation and aggradation and the stratigraphic evolution of channel-levee systems: Journal of the Geological Society, v. 168, 
no. 3, p. 625-628. http://doi.org/10.1144/001676492010-177

Hodgson, D.M., Kane, I.A., Flint, S.S., Brunt, R.L., and Ortiz-Karpf, Andrea, 2016, Time-transgressive confinement on the slope and the progradation of basin-floor fans-Implications for the sequence stratigraphy of deep-water deposits: Journal of Sedimentary Research, v. 86, no. 3, p. 73-86. http://doi. org/10.2110/jsr.2016.3

Hubbard, S.M., Covault, J.A., Fildani, Andrea, and Romans, B.W., 2014, Sediment transfer and deposition in slope channels-Deciphering the record of enigmatic deep-sea processes from outcrop: Geological Society of America Bulletin, v. 126, no. 5-6, p. 857-871. http://doi.org/10.1130/B30996.1

Hubbard, S.M., MacEachern, J.A., and Bann, K.L., 2012, Slopes, in Knaust, Dirk, and Bromley, R.G., eds., Trace fossils as indicators of sedimentary environments: Developments in Sedimentology, v. 64, p. 607-642. http://dx.doi.org/10.1016/B978-0-44453813-0.00020-4

Hubbard, S.M., Romans, B.W., and Graham, S.A., 2008, Deep-water foreland basin deposits of the Cerro Toro Formation, Magallanes Basin, Chile-Architectural elements of a sinuous basin axial channel belt: Sedimentology, v. 55, no. 5, p. 1,333-1,359. http:// doi.org/10.1111/j.1365-3091.2007.00948.x

Hunt, Dave, and Tucker, M.E., 1992, Stranded parasequences and the forced regressive wedge systems tract-Deposition during base-level fall: Sedimentary Geology, v. 81, no. 1-2, p. 1-9. http:// doi.org/10.1016/0037-0738(92)90052-S

Imlay, R.W., 1975, Stratigraphic distribution and zonation of Jurassic (Callovian) ammonites in southern Alaska: U.S. Geological Survey Professional Paper 836, 28 p. https://pubs.er.usgs.gov/publication/ pp836

Imlay, R.W., 1981, Late Jurassic ammonites from Alaska: U.S. Geological Survey Professional Paper 1190, 40 p. https://pubs.er.usgs.gov/publication/pp1190

Jervey, M.T., 1988, Quantitative geological modeling of siliciclastic rock sequences and their seismic expression, in Wilgus, C.K., Hastings, B.S., Posamentier, H.W., Van Wagoner, J.C., Ross, C.A., and Kendall, C.G.St.C., eds., Sea-level changes-An integrated approach: Society of Economic Paleontologists and Mineralogists (SEPM) Special Publication 42, p. 47-69. http://doi.org/10.2110/pec.88.01.0047

Jobe, Z.R., Lowe, D.R., and Uchytil, S.J., 2011, Two fundamentally different types of submarine canyons along the continental margin of Equatorial Guinea: Marine and Petroleum Geology, v. 28, no. 3, p. 843-860. http://doi.org/10.1016/j.marpetgeo.2010.07.012
Kane, I.A., and Hodgson, D.M., 2011, Sedimentological criteria to differentiate submarine channel levee subenvironments-Exhumed examples from the Rosario Formation (Upper Cretaceous) of Baja California, Mexico, and the Fort Brown Formation (Permian), Karoo Basin, South Africa: Marine and Petroleum Geology, v. 28, p. 807-823. http://doi. org/10.1016/j.marpetgeo.2010.05.009

Kane, I.A., Dykstra, Mason, Kneller, B.C., Tremblay, Sacha, and McCaffrey, W.D., 2009, Architecture of a coarse-grained channel-levée system-The Rosario Formation, Baja California, Mexico: Sedimentology, v. 56, no. 7, p. 2,207-2,234. http://doi.org/10.1111/ j.1365-3091.2009.01077.x

Kane, I.A., Kneller, B.C., Dykstra, Mason, Kassem, A., and McCaffrey, W.D., 2007, Anatomy of a submarine channel-levee-An example from upper Cretaceous slope sediments, Rosario Formation, Baja California, Mexico: Marine and Petroleum Geology, v. 24, no. 6-9, p. 540-563. http://doi.org/10.1016/j.marpetgeo.2007.01.003

Kirschner, C.E., and Lyon, C.A., 1973, Stratigraphic and tectonic development of Cook Inlet petroleum province, in Pitcher, M.G., ed., Arctic Geology: American Association of Petroleum Geologists Memoir 19, p. 396-407.

Kirschner, C.E., and Minard, D.L., 1949, Geology of the Iniskin Peninsula, Alaska: U.S. Geological Survey Oil and Gas Investigations Map 95, 1 sheet, scale 1:48,000. http://www.dggs.alaska.gov/pubs/id/23613

Koppes, M.N., and Montgomery, D.R., 2009, The relative efficacy of fluvial and glacial erosion over modern to orogenic timescales: Nature Geoscience, v. 2, no. 9, p. 644-647. http://doi.org/10.1038/ngeo616

LePain, D.L., Lillis, P.G., Helmold, K.P., and Stanley, R.G., 2012, Migrated hydrocarbons in exposure of Maastrichtian nonmarine strata near Saddle Mountain, lower Cook Inlet, Alaska: Alaska Division of Geological \& Geophysical Surveys Report of Investigation 2012-1, 13 p. http://doi.org/10.14509/23943

LePain, D.L., Stanley, R.G., Helmold, K.P., and Shellenbaum, D.P., 2013, Geologic framework and petroleum systems of Cook Inlet basin, south-central Alaska, in Stone, D.M., and Hite, D.M., eds., Oil and Gas Fields of the Cook Inlet Basin: American Association of Petroleum Geologists Memoir 104, p. 37-116.

Lyle, W.M., and Morehouse, J.A., 1977, Physical parameters of potential petroleum reservoir and source rocks in the Kamishak-Iniskin-Tuxedni region, lower Cook Inlet: Alaska Division of Geological \& Geophysical Surveys Alaska Open-File Report 104, 79 p., 13 sheets, scale 1:250,000. http://doi. org/10.14509/9 
Macauley, R.V., and Hubbard, S.M., 2013, Slope channel sedimentary processes and stratigraphic stacking, Cretaceous Tres Pasos Formation slope system, Chilean Patagonia: Marine and Petroleum Geology, v. 41, p. 146-162. http://doi.org/10.1016/j.marpetgeo.2012.02.004

Magoon, L.B., ed., 1986a, Geologic studies of the lower Cook Inlet COST No. 1 well, Alaska outer continental shelf: U.S. Geological Survey Bulletin 1596, 99 p. https://pubs.er.usgs.gov/publication/b1596

Magoon, L.B., 1986b, Stratigraphic units of the COST No. 1 well, in Magoon, L.B., ed., Geologic studies of the lower Cook Inlet COST No. 1 well, Alaska outer continental shelf: U.S. Geological Survey Bulletin 1596, p. 17-22. https://pubs.er.usgs.gov/publication/b1596

Magoon, L.B., Griesbach, F.B., and Egbert, R.M., 1980, Nonmarine Upper Cretaceous rocks, Cook Inlet, Alaska: American Association of Petroleum Geologists Bulletin, v. 64, no. 8, p. 1,259-1,266.

Magoon, L.B., Hampton, M.A., Sable, E.G., Smith, R.A., and Chmelik, F.B., 1975, Hydrocarbon potential, geologic hazards, and the technology, time-frame, and infrastructure for exploration and development of the lower Cook Inlet, Alaska, a preliminary assessment: U.S. Geological Survey Open-File Report 75-549, 74 p. https://pubs.er.usgs.gov/publication/ ofr75549

Martin, G.C., 1905, The petroleum fields of the Pacific coast of Alaska, with an account of the Bering River coal deposits: U.S. Geological Survey Bulletin 250, 64 p. https://pubs.er.usgs.gov/publication/b250

Martin, G.C., and Katz, F.J., 1912, A geologic reconnaissance of the Iliamna region, Alaska: U.S. Geological Survey Bulletin 485, 138 p., 2 sheets, scale 1:250,000. https://pubs.er.usgs.gov/publication/b485

Mayall, Mike, Jones, Ed, and Casey, Mick, 2006, Turbidite channel reservoirs-Key elements in facies prediction and effective development: Marine and Petroleum Geology, v. 23, no. 8, p. 821-841. http:// doi.org/10.1016/j.marpetgeo.2006.08.001

Miall, A.D., 2010, The Geology of Stratigraphic Sequences (second edition): Berlin, Springer-Verlag, $522 \mathrm{p}$.

Miall, A.D., and Miall, C.E., 2001, Sequence stratigraphy as a scientific enterprise-The evolution and persistence of conflicting paradigms: EarthScience Reviews, v. 54, no. 4, p. 321-348. http://doi. org/10.1016/S0012-8252(00)00041-6

Moffit, F.H., 1927, The Iniskin-Chinitna Peninsula and the Snug Harbor district, Alaska: U.S. Geological Survey Bulletin 789, 71 p., 5 sheets, scale 1:250,000. https://pubs.er.usgs.gov/publication/b789
Molnar, Peter, and England, Philip, 1990, Late Cenozoic uplift of mountain ranges and global climate change-Chicken or egg?: Nature, v. 346, no. 6279, p. 29-34. http://doi.org/10.1038/346029a0

Morris, W.R., and Busby-Spera, C.J., 1988, Sedimentologic evolution of a submarine canyon in a forearc basin, Upper Cretaceous Rosario Formation, San Carlos, Mexico: American Association of Petroleum Geologists, v. 72, p. 717-737.

Morris, W.R., and Busby-Spera, C.J., 1990, A submarine-fan valley-levee complex in the Upper Cretaceous Rosario Formation-Implications for turbidite facies models: Geological Society of America Bulletin, v. 102, no. 7, p. 900-914. http:// doi.org/10.1130/0016-7606(1990)102<0900:ASFV LC>2.3.CO;2

Morris, E.A., Hodgson, D.M., Brunt, R.L., and Flint, S.S., 2014, Origin, evolution and anatomy of silt-prone submarine external levées: Sedimentology, v. 61, no. 6, p. 1,734-1,763. http://doi.org/10.1111/sed.12114 Mutti, Emiliano, and Normark, W.R., 1987, Comparing Examples of Modern and Ancient Turbidite Systems-Problems and Concepts, in Leggett, J.K., and Zuffa, G.G., eds., Marine Clastic Sedimentology: London, Graham \& Trotman, p. 1-38.

Mutti, Emiliano, Tinterri, Roberto, Remacha, Eduard, Mavilla, Nicola, Angella, Stefano, and Fava, Luca, 1999, An introduction to the analysis of ancient turbidite basins from an outcrop perspective: American Association of Petroleum Geologists Continuing Education Course Note Series \#39, 61 p.

Neal, Jack, and Abreu, Vitor, 2009, Sequence stratigraphy hierarchy and the accommodation succession method: Geology, v. 37, no. 9, p. 779-782. http://doi. org/10.1130/G25722A.1

Nelson, R.A., 2001, Geologic Analysis of Naturally Fractured Reservoirs (second edition): Houston, Gulf Publishing, 320 p.

Noda, Atsushi, 2016, Forearc basins-Types, geometries, and relationships to subduction zone dynamics: Geological Society of America Bulletin, v. 128, no. 5-6, p. 879-895. http://doi.org/10.1130/B31345.1

Normark, W.R., and Carlson, P.R., 2003, Giant submarine canyons-Is size any clue to their importance in the rock record?, in Chan, M.A., and Archer, A.W., eds., Extreme depositional environments-Mega end members in geologic time: Geological Society of America Special Paper 370, p. 175-190. http://doi. org/10.1130/0-8137-2370-1.175

Ogg, J.G., and Hinnov, L.A., 2012, Jurassic, in Gradstein, F.M., Ogg, J.G., Schmitz, M.D., and Ogg, G.M., eds., The Geologic Time Scale 2012: Oxford, Elsevier, p. 731-791. http://dx.doi.org/10.1016/B978-0-44459425-9.00026-3 
Pavlis, T.L., and Roeske, S.M., 2007, The Border Ranges fault system, southern Alaska, in Ridgway, K.D., Trop, J.M., Glen, J.M.G., and O’Neill, J.M., eds., Tectonic growth of a collisional continental marginCrustal evolution of southern Alaska: Geological Society of America Special Paper 431, p. 95-127. http://doi.org/10.1130/2007.2431(05)

Payton, C.E., ed., 1977, Seismic stratigraphy-Applications to hydrocarbon exploration: American Association of Petroleum Geologists Memoir 26, 516 p.

Peakall, Jeff, McCaffrey, Bill, and Kneller, Ben, 2000, A process model for the evolution, morphology, and architecture of sinuous submarine channels: Journal of Sedimentary Research, v. 70, no. 3, p. 434-448. http://doi.org/10.1306/2DC4091C-0E47-11D78643000102C1865D

Peizhen, Zhang, Molnar, Peter, and Downs, W.R., 2001, Increased sedimentation rates and grain sizes 2-4 Myr ago due to the influence of climate change on erosion rates: Nature, v. 410 , no. 6,831, p. 891-897. http://doi.org/10.1038/35073504

Pickering, K.T., Hiscott, R.N., and Hein, F.J., 1989, "Submarine canyons, gullies and other sea valleys" (Chapter 6), in Deep Marine Environments-Clastic Sedimentation and Tectonics: London, Unwyn Hyman, p. 133-159.

Piper, D.J.W., and Normark, W.R., 2001, Sandy fansFrom Amazon to Hueneme and beyond: American Association of Petroleum Geologists Bulletin, v. 85, no. 8 , p. 1,407-1,438.

Pirmez, Carlos, Beaubouef, R.T., and Friedmann, S.J., 2000, Equilibrium profile and base level in submarine channels-Examples from Late Pleistocene systems and implications for the architecture of deepwater reservoirs, in Weimer, P., Slatt, R.M., Coleman, J.L., Rosen, N., Nelson, C.H., Bouma, A.H., Styzen, M., and Lawrence, D.T., eds., Global deep-water reservoirs: Gulf Coast Section, SEPM Foundation 20th Annual Bob F. Perkins Research Conference, p. 782-805.

Plint, A.G., 1991, High frequency relative sea level oscillations in Upper Cretaceous shelf clastics of the Alberta foreland basin-Possible evidence of a glacio-eustatic control?, in Macdonald, D.I.M., ed., Sedimentation, Tectonics, and Eustasy: International Association of Sedimentologists Special Publications, v. 12, p. 409-428. http://doi. org/10.1002/9781444303896.ch22

Plint, A.G., and Nummedal, Dag, 2000, The falling stage systems tract-Recognition and importance in sequence stratigraphic analysis, in Hunt, D., and Gawthorpe, R.L., eds., Sedimentary Responses to Forced Regression: Geological Society, London,
Special Publications, v. 172, p. 1-17. http://doi. org/10.1144/GSL.SP.2000.172.01.01

Porębski, S.J., and Steel, R.J., 2003, Shelf-margin deltas-Their stratigraphic significance and relation to deepwater sands: Earth-Science Reviews, v. 62, no. 3-4, p. 283-326. http://doi.org/10.1016/S0012$\underline{\text { 8252(02)00161-7 }}$

Posamentier, H.W., and Allen, G.P., 1999, Siliciclastic sequence stratigraphy-Concepts and applications: Society for Sedimentary Geology, SEPM Concepts in Sedimentology and Paleontology \#7, 210 p. http:// doi.org/10.2110/csp.99.07.0001

Posamentier, H.W., and Kolla, Venkatarathnan, 2003, Seismic geomorphology and stratigraphy of depositional elements in deep-water settings: Journal of Sedimentary Research, v. 73, no. 3, p. 367-388. http://doi.org/10.1306/111302730367

Posamentier, H.W., and Morris, W.R., 2000, Aspects of the stratal architecture of forced regressive deposits, in Hunt, D., and Gawthorpe, R.L., eds., Sedimentary responses to forced regressions: Geological Society of London, Special Publications, v. 172, p. 19-46. http://doi.org/10.1144/GSL.SP.2000.172.01.02

Posamentier, H.W., and Vail, P.R., 1988, Eustatic controls on clastic deposition II-Sequence and systems tract models, in Wilgus, C.K., Hastings, B.S., Kendall, C.G.St.C., Posamentier, H.W., Ross, C.A., and Van Wagoner, J.C., eds., Sea-level changes-An integrated approach: Society of Economic Paleontologists and Mineralogists (SEPM) Special Publication 42, p. 125-154. http://doi.org/10.2110/pec.88.01.0125

Posamentier, H.W., and Walker, R.G., 2006, Deep-water turbidites and submarine fans, in Posamentier, H.W., and Walker, R.G., eds., Facies model revisited: SEPM Special Publication v. 84, Society for Sedimentary Geology, p. 397-520. http://doi.org/10.2110/ pec.06.84.0399

Posamentier, H.W., Allen, G.P., James, D.P., and Tesson, Michel, 1992, Forced regressions in a sequence stratigraphic framework-Concepts, examples, and exploration significance: American Association of Petroleum Geologists Bulletin, v. 76, p. 1,687-1,709.

Posamentier, H.W., Jervey, M.T., Vail, P.R., 1988, Eustatic controls on clastic deposition I-conceptual framework, in Wilgus, C.K., Hastings, B.S., Kendall, C.G.St.C., Posamentier, H.W., Ross, C.A., and Van Wagoner, J.C., eds., Sea-level changes-An integrated approach: Society of Economic Paleontologists and Mineralogists (SEPM) Special Publication No. 42, p. 109-124. http://doi.org/10.2110/pec.88.01.0109

Prather, B.E., 2003, Controls on reservoir distribution, architecture and stratigraphic trapping in slope settings: Marine and Petroleum Geology, v. 20, no. 
6-8, p. 529-545. http://doi.org/10.1016/j.marpetgeo.2003.03.009

Reading, H.G., and Richards, Marcus, 1994, Turbidite systems in deep-water basin margins classified by grain size and feeder system: American Association of Petroleum Geologists Bulletin, v. 78, no. 5, p. $792-822$.

Reed, B.L., and Lanphere, M.A., 1973, Alaska-Aleutian Range batholith-Geochronology, chemistry, and relation to circum-Pacific plutonism: Geological Society of America Bulletin, v. 84, no. 8, p. 2,583-2,610. http://doi.org/10.1130/00167606(1973)84<2583:ARBGCA >2.0.CO;2

Reed, B.L., Miesch, A.T., and Lanphere, M.A., 1983, Plutonic rocks of Jurassic age in the Alaska-Aleutian Range batholith-Chemical variations and polarity: Geological Society of America Bulletin, v. 94, no. 10, p. 1,232-1,240. http://doi.org/10.1130/00167606(1983)94<1232:PROJAI >2.0.CO;2

Richards, Marcus, and Bowman, M., 1998, Submarine fans and related depositional systems II-Variability in reservoir architecture and wireline log character: Marine and Petroleum Geology, v. 15, no. 8, p. 821839. http://doi.org/10.1016/S0264-8172(98)00042-7

Richards, Marcus, Bowman, M., and Reading, H.G., 1998, Submarine-fan systems I-Characterization and stratigraphic prediction: Marine and Petroleum Geology, v. 15, no. 7, p. 687-717. http://doi. org/10.1016/S0264-8172(98)00036-1

Rioux, Matthew, Mattinson, James, Hacker, Bradley, Kelemen, Peter, Blusztajn, Jurek, Hanghoj, Karen, and Gehrels, George, 2010, Intermediate to felsic middle crust in the accreted Talkeetna arc, the Alaska Peninsula and Kodiak Island, Alaska-An analogue for low-velocity middle crust in modern arcs: Tectonics, v. 29, no. 3, 17 p. http://doi. org/10.1029/2009TC002541

Rosenthal, Jacob L., in preparation, Fractured reservoir potential and tectonic development of the Iniskin-Tuxedni region, lower Cook Inlet, Alaska: Fairbanks, University of Alaska Fairbanks, Master of Science thesis.

Rosenthal, J.L., Betka, P.M., Gillis, R.J., and Nadin, Elisabeth, 2015b, Preliminary investigation of fracture populations in Mesozoic strata of the Cook Inlet forearc basin-Iniskin Peninsula and Lake Clark National Park, Alaska, in Wartes, M.A., ed., Energy-related studies during the 2014 field season, western Cook Inlet, Alaska: Alaska Division of Geological \& Geophysical Surveys Preliminary Interpretive Report 2015-5-3, p. 9-13. http://doi. org/10.14509/29458
Rosenthal, J.L., Betka, P.M., Gillis, R.J., and Nadin, Elisabeth, 2016, Fracture intensity in the Paveloff Siltstone Member (Chinitna Formation) and Pomeroy Arkose Member (Naknek Formation), Iniskin Peninsula, Alaska-Implications for hydrocarbon migration in Cook Inlet basin, in Herriott, T.M., ed., Petroleumrelated geologic studies in lower Cook Inlet during 2015, Iniskin-Tuxedni region, south-central Alaska: Alaska Division of Geological \& Geophysical Surveys Preliminary Interpretive Report 2016-1-9, p. 67-72. http://doi.org/10.14509/29543

Rosenthal, J.L., Betka, P.M., Nadin, E.S., and Gillis, R.J., 2015a, Deformational history and fracture intensity of the Iniskin Peninsula, Cook Inlet, Alaska [abs.]: Geological Society of America, Cordilleran Section Annual Meeting, May 11-13, 2015, Anchorage, Alaska.

Satur, N., Kelling, G., Cronin, B.T., Hurst, A., and Gürbüz, K., 2005, Sedimentary architecture of a canyonstyle fairway feeding a deep-water clastic system, the Miocene Cingöz Formation, southern Turkey-Significance for reservoir characterisation and modelling: Sedimentary Geology, v. 173, no. 1-4, p. 91-119. http://doi.org/10.1016/j.sedgeo.2003.11.024

Shepard, F.P., 1981, Submarine canyons-Multiple causes and long-time persistence: American Association of Petroleum Geologists Bulletin, v. 65, p. 1,062-1,077.

Sprague, A.R.G., Garfield, T.R., Goulding, F.J., Beaubouef, R.T., Sullivan, M.D., Rossen, C., Campion, K.M., Sickafoose, D.K., Abreu, Vitor, Schellpeper, M.E., Jensen, G.N., Jennette, D.C., Pirmez, Carlos, Dixon, B.T., Ying, D., Ardill, J., Mohrig, D.C., Porter, M.L., Farrell, M.E., and Mellere, D., 2005, Integrated Slope Channel Depositional Models-The Key to Successful Prediction of Reservoir Presence and Quality in Offshore West Africa: Veracruz, Mexico, CIPM (Mexican College of Oil Engineers), 13 p.

Spurr, J.E., 1900, A reconnaissance in southwestern Alaska in 1898, in Walcott, C.D., ed., Twentieth annual report of the United States Geological Survey, 1898-1899; Part VII-Explorations in Alaska in 1898: U.S. Geological Survey Annual Report 20VII, p. 31-264. http://www.dggs.alaska.gov/pubs/ $\underline{\mathrm{id} / 25668}$

Stanley, R.G., Charpentier, R.R., Cook, T.A., Houseknecht, D.W., Klett, T.R., Lewis, K.A., Lillis, P.G., Nelson, P.H., Phillips, J.D., Pollastro, R.M., Potter, C.J., Rouse, W.A., Saltus, R.W., Schenk, C.J., Shah, A.K., and Valin, Z.C., 2011a, Assessment of undiscovered oil and gas resources of the Cook Inlet region, south-central Alaska, 2011: U.S. Geological 
Survey Fact Sheet 2011-3068, 2 p. https://pubs.usgs. gov/fs/2011/3068/

Stanley, R.G., Herriott, T.M., Helmold, K.P., Gillis, R.J., and Lillis, P.G., 2013, Hydrocarbon-bearing sandstone in the Upper Jurassic Naknek formation on the south shore of Kamishak Bay, in Gillis, R.J., ed., Overview of 2012 field studies-Upper Alaska Peninsula and west side of lower Cook Inlet, Alaska: Alaska Division of Geological \& Geophysical Surveys Preliminary Interpretive Report 2013-1E, p. 19-23. http://doi.org/10.14509/24848

Stanley, R.G., Pierce, B.S., and Houseknecht, D.W., 2011b, U.S. Geological Survey 2011 assessment of undiscovered oil and gas resources of the Cook Inlet region, south-central Alaska: U.S. Geological Survey Open-File Report 2011-1237, 37 p. https:// pubs.usgs.gov/of/2011/1237/

Stevenson, C.J., Jackson, C.A.-L., Hodgson, D.M., Hubbard, S.M., and Eggenhuisen, J.T., 2015, Deep-water sediment bypass: Journal of Sedimentary Research, v. 85 , no. 9 , p. 1,058-1,081. http://doi.org/10.2110/ jsr.2015.63

Stow, D.A.V., and Mayall, Mike, 2000, Deep-water sedimentary systems-New models for the 21st century: Marine and Petroleum Geology, v. 17, no. 2, p. 125135. http://doi.org/10.1016/S0264-8172(99)00064-1

Strong, Nikki, and Paola, Chris, 2008, Valleys that never were-Time surfaces versus stratigraphic surfaces: Journal of Sedimentary Research, v. 78, no. 8, p. 579-593. http://doi.org/10.2110/jsr.2008.059

Sweet, M.L., and Blum, M.D., 2016, Connections between fluvial to shallow marine environments and submarine canyons-Implications for sediment transfer to deep water: Journal of Sedimentary Research, v. 86, p. 1,147-1,162. http://doi. org/10.2110/jsr.2016.64

Sylvester, Zoltán, Pirmez, Carlos, and Cantelli, Alessandro, 2011, A model of submarine channel-levee evolution based on channel trajectories-Implications for stratigraphic architecture: Marine and Petroleum Geology, v. 28, no. 3, p. 716-727. http:// doi.org/10.1016/j.marpetgeo.2010.05.012

Trop, J.M., and Ridgway, K.D., 2007, Mesozoic and Cenozoic tectonic growth of southern Alaska-A sedimentary basin perspective, in Ridgway, K.D., Trop, J.M., Glen, J.M.G., and O'Neill, J.M., eds., Tectonic growth of a collisional continental margin-Crustal evolution of southern Alaska: Geological Society of America Special Paper 431, p. 55-94. http://doi. org/10.1130/2007.2431(04)

Trop, J.M., Szuch, D.A., Rioux, Matthew, and Blodgett, R.B., 2005, Sedimentology and provenance of the Upper Jurassic Naknek Formation, Talkeetna
Mountains, Alaska-Bearings on the accretionary tectonic history of the Wrangellia composite terrane: Geological Society of America Bulletin, v. 117, no. 5-6, p. 570-588. http://doi.org/10.1130/B25575.1

Turner, R.F., 1986, Paleontology and biostratigraphy of the COST No. 1 well, in Magoon, L.B., ed., Geologic studies of the lower Cook Inlet COST No. 1 well, Alaska outer continental shelf: U.S. Geological Survey Bulletin 1596, p. 29-31.

Vail, P.R., Mitchum, R.M., Jr., Todd, R.G., Widmier, J.M., Thompson, S., III, Sangree, J.B., Bubb, J.N., and Hatlelid, W.G., 1977, Seismic stratigraphy and global changes of sea level, in Payton, C.E., ed., Seismic stratigraphy-Applications to hydrocarbon exploration: American Association of Petroleum Geologists Memoir 26, p. 49-212.

Van Wagoner, J.C., Posamentier, H.W., Mitchum, R.M., Vail, P.R., Sarg, J.F., Loutit, T.S., and Hardenbol, J., 1988, An overview of sequence stratigraphy and key definitions, in Wilgus, C.K., Hastings, B.S., Kendall, C.G.St.C., Posamentier, H.W., Ross, C.A., and Van Wagoner, J.C., eds., Sea-level changes-An integrated approach: Society of Economic Paleontologists and Mineralogists (SEPM) Special Publication No. 42, p. 39-45. http://doi.org/10.2110/pec.88.01.0039 Wartes, M.A., ed., 2015a, Energy-related studies during the 2014 field season, western Cook Inlet, Alaska: Alaska Division of Geological \& Geophysical Surveys Preliminary Interpretive Report 2015-5, 62 p. http://doi.org/10.14509/29455

Wartes, M.A., 2015b, An introduction to 2014 field studies in western Cook Inlet, Alaska, in Wartes, M.A., ed., Energy-related studies during the 2014 field season, western Cook Inlet, Alaska: Alaska Division of Geological \& Geophysical Surveys Preliminary Interpretive Report 2015-5-1, p. 1-4. http://doi. org/10.14509/29456

Wartes, M.A., and Decker, P.L., 2015, Late Jurassic glaciers during the Mesozoic greenhouse-Evidence from the lower Naknek Formation, southern Alaska: Geological Society of America, Cordilleran Section, Abstracts with Programs, v. 47, no. 4, paper no. 5, p. 8. https://gsa.confex.com/gsa/2015CD/webprogram/Paper255138.html

Wartes, M.A., and Herriott, T.M., 2014, A new occurrence of oil-stained rocks within a small fault zone involving the Middle Jurassic Cynthia Falls Formation, Tuxedni Group, northern Iniskin Peninsula, in Gillis, R.J., ed., Cook Inlet program 2013 field studies-Observations and preliminary interpretations from new 1:63,360-scale geologic mapping of the Iniskin Peninsula, lower Cook Inlet, Alaska: Alaska Division of Geological \& Geophysical Surveys Pre- 
liminary Interpretive Report 2014-2-5, p. 23-27. http://doi.org/10.14509/27310

Wartes, M.A., and Herriott, T.M., 2015, Oil-stained sandstone in the Middle Jurassic lower Paveloff Siltstone Member of the Chinitna FormationExploring the potential role of facies variations in controlling diagenesis and reservoir quality in western Cook Inlet, Alaska: Alaska Division of Geological \& Geophysical Surveys Preliminary Interpretive Report 2015-7, 9 p. http://doi.org/10.14509/29533

Wartes, M.A., Decker, P.L., Herriott, T.M., and Helmold, K.P., 2015, Preliminary facies analysis of the lower sandstone member of the Upper Jurassic Naknek Formation, northern Chinitna Bay, Alaska, in Wartes, M.A., ed., Energy-related studies during the 2014 field season, western Cook Inlet, Alaska: Alaska Division of Geological \& Geophysical Surveys Preliminary Interpretive Report 2015-5-8, p. 49-55. http://doi.org/10.14509/29463

Wartes, M.A., Gillis, R.J., and Harun, N.T., 201, Revised mapping of the Upper Jurassic Naknek Formation in a footwall syncline associated with the Bruin Bay fault system, Chinitna Bay region, western Cook Inlet, Alaska, in Herriott, T.M., ed., Petroleumrelated geologic studies in lower Cook Inlet during 2015, Iniskin-Tuxedni region, south-central Alaska: Alaska Division of Geological \& Geophysical Surveys Preliminary Interpretive Report 2016-1-8, p. 59-66. http://doi.org/10.14509/29542

Wartes, M.A., Herriott, T.M., Helmold, K.P., and Gillis, R.J., 2013, Preliminary stratigraphic interpretation of the Naknek Formation-Evidence for Late Jurassic activity on the Bruin Bay fault, Iniskin Peninsula, lower Cook Inlet, in Gillis, R.J., ed., Overview of 2012 field studies-Upper Alaska Peninsula and west side of lower Cook Inlet, Alaska: Alaska Division of Geological \& Geophysical Surveys Preliminary Interpretive Report 2013-1H, p. 39-46, http://doi. org/10.14509/24851

Wartes, M.A., Herriott, T.M., Helmold, K.P., Gillis, R.J., LePain, D.L., and Stanley, R.G., 2011, Stratigraphic evidence for Late Jurassic activity on the Bruin Bay fault, Iniskin Peninsula, lower Cook Inlet, Alaska [abs.]: American Association of Petroleum Geologists, Pacific Section Annual Meeting, p. 96-97.

Weimer, Paul, and Slatt, R.M., 2007, Introduction to the petroleum geology of deepwater settings: American Association of Petroleum Geologists Studies in Geology, v. 57, 846 p. http://doi.org/10.1306/St571314C1
Whipple, K.X., 2009, The influence of climate on the tectonic evolution of mountain belts: Nature Geoscience, v. 2, no. 2, p. 97-104. http://doi.org/10.1038/ ngeo413

Williams, T.A., and Graham, S.A., 2013, Controls on forearc basin architecture from seismic and sequence stratigraphy of the Upper Cretaceous Great Valley Group, central Sacramento Basin, California: International Geology Review, v. 55, no. 16, p. 2,030-2,059. http://doi.org/10.1080/00206814.201 $\underline{3.817520}$

Williams, T.A., Graham, S.A., and Constenius, K.N., 1998, Recognition of a Santonian submarine canyon, Great Valley Group, Sacramento Basin, California-Implications for petroleum exploration and sequence stratigraphy of deep-marine strata: American Association of Petroleum Geologists Bulletin, v. 82 , no. 8, p. 1,575-1,595.

Wilson, F.H., Dover, J.H., Bradley, D.C., Weber, F.R., Bundtzen, T.K., and Haeussler, P.J., 1998, Geologic map of central (interior) Alaska: U.S. Geological Survey Open-File Report 98-133-A, 62 p., 3 sheets, scale 1:500,000. https://pubs.usgs.gov/of/1998/ of $98-133-\mathrm{a} /$

Wilson, F.H., Hults, C.P., Schmoll, H.R., Haeussler, P.J., Schmidt, J.M., Yehle, L.A., and Labay, K.A., compilers, 2009, Preliminary geologic map of the Cook Inlet region, Alaska: U.S. Geological Survey Open-File Report 2009-1108, 52 p., 2 sheets, scale 1:250,000. https://pubs.usgs.gov/of/2009/1108/

Wilson, F.H., Hults, C.P., Schmoll, H.R., Haeussler, P.J., Schmidt, J.M., Yehle, L.A., and Labay, K.A., compilers, 2012, Geologic map of the Cook Inlet region, Alaska, including parts of the Talkeetna, Talkeetna Mountains, Tyonek, Anchorage, Lake Clark, Kenai, Seward, Iliamna, Seldovia, Mount Katmai, and Afognak: U.S. Geological Survey Scientific Investigations Map 3153, 76 p., 2 sheets, scale 1:250,000. https:// pubs.usgs.gov/sim/3153/

Wynn, R.B., Kenyon, N.H., Masson, D.G., Stow, D.A.V., and Weaver, P.P.E., 2002, Characterization and recognition of deep-water channel-lobe transition zones: American Association of Petroleum Geologists Bulletin, v. 86, no. 8, p. 1,441-1,462.

Xie, Xiangyang, and Heller, P.L., 2009, Plate tectonics and basin subsidence history: Geological Society of America Bulletin, v. 121, no. 1-2, p. 55-64. http:// doi.org/10.1130/B26398.1 